\title{
Geology of Parts of
}

The Upper Mississippi Valley Zinc-Lead District

G EOLOG I CAL S URVEY BULLETIN 1123

This volume was published as separate chapters $A-I$.

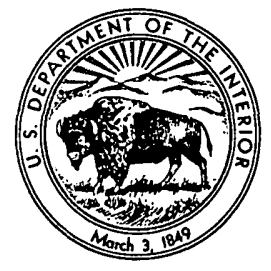


UNITED STATES DEPARTMENT OF THE INTERIOR

STEWART L. UDALL, Secretary

\section{GEOLOGICAL SURVEY}

William T. Pecora, Director 


\section{CONTENTS}

[Letters designate the separately published chapters]

(A) Geology of the Dubuque South quadrangle, Iowa-Illinois, by C. Ervin Page Brown and Jesse W. Whitlow

(B) Geology of the Montfort and Linden quadrangles, Wisconsin, by John E. Carlson

(C) Geology of the Dubuque North quadrangle, Iowa-Wisconsin-Illinois, by Jesse W. Whitlow and C. Ervin Brown

(D) Geology of the Dodgeville and Mineral Point quadrangles, Wisconsin, by John W. Allingham

(E) Geology of the Platteville quadrangle, Wisconsin, by Allen F. Agnew_

(F) Geology of the Rewey and Mifflin quadrangles, Wisconsin, by Alfred R. Taylor-

(G) Geology of the Belmont and Calamine quadrangles, Wisconsin, by Harry Klemic and Walter S. West.

(H) Geology of the Cuba City, New Diggings, and Shullsburg quadrangles, Wisconsin and Illinois, by Thomas E. Mullens

(I) Geology of the Potosi quadrangle, Grant County, Wisconsin, and Dubuque County, Iowa, by Jesse W. Whitlow and Walter S. West_ 
c.

\section{Geology of the \\ Dubuque South Quadrangle Iowa-Illinois}

GEOLOG I A L S U RVEY BULLETIN $1123-A$

Prepared in cooperation with the Iowa Geological Survey

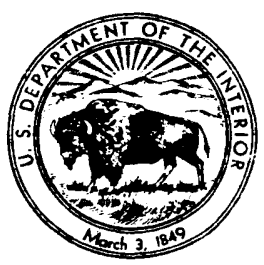

QE 75

B9

$n 0.1123 A-D$

- 6.6 . 


\section{Geology of the}

\section{Dubuque South Quadrangle Iowa-Illinois}

N. ERVIN BROWN and JESSE W. WHITLOW

GEOLOGY OF PARTS OF THE UPPER MISSISSIPPI VALLEY ZINC-LEAD DISTRICT

GE O L O G I C A L S U R V E Y B U L L E T I N 1123 -A

Prepared in cooperation with the Iowa Geological Survey

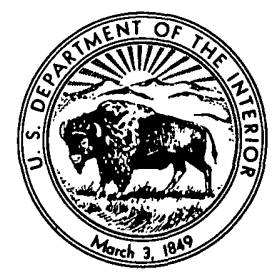


UNITED STATES DEPARTMENT OF THE INTERIOR

FRED A. SEATON, Secretary

\section{GEOLOGIGAL SURVEY}

Thomas B. Nolan, Director

For sale by the Superintendent of Documents, U.S. Government Printing Office Washington 25, D.C. 


\section{CONTENTS}

\begin{tabular}{|c|c|}
\hline & ige \\
\hline & \\
\hline Introduction & 2 \\
\hline Location and accessibility _. . & \\
\hline Previous work & \\
\hline Purpose of the investigation & \\
\hline Field and laboratory work & \\
\hline Acknowledgments & \\
\hline Physiography & \\
\hline Drainage & \\
\hline Erosional history of the drainage system & \\
\hline Alluvial terraces & \\
\hline Incised meanders and abandoned chaunels & \\
\hline Cuesta_n & \\
\hline Sinkholes and caves & 10 \\
\hline Stratigraphy & 10 \\
\hline Precambrian and Cambrian systems & 12 \\
\hline Ordovician system & 13 \\
\hline Lower Ordovician series & 13 \\
\hline Prairie du Chien group. & 13 \\
\hline Middle Ordovician series & 13 \\
\hline St. Peter sandstone & 13 \\
\hline Platteville formation & 13 \\
\hline Glenwood shale member & 13 \\
\hline Pecatonica dolomite member & 14 \\
\hline McGregor limestone member & 1.4 \\
\hline Quimbys Mill member & 1.4 \\
\hline Decorah formation & 15 \\
\hline Spechts Ferry shale member & 15 \\
\hline Guttenberg limestone member & 15 \\
\hline Ion dolomite member & 16 \\
\hline Galena dolomite & 1.6 \\
\hline Cherty unit. & 17 \\
\hline Noncherty unit & 21 \\
\hline Upper Ordovician series & 22 \\
\hline Maquoketa shale & 22 \\
\hline Brown shaly unit. & 25 \\
\hline Brainard member & 27 \\
\hline Neda member & 28 \\
\hline Silurian system & 31 \\
\hline Lower Silurian series. & 34 \\
\hline Edgewood dolomite- & 34 \\
\hline Mosalem member & 36 \\
\hline Tete des Morts member & 39 \\
\hline Kankakee formation & 40 \\
\hline Middle Silurian series. & 43 \\
\hline Hopkinton dolomite.............. & 43 \\
\hline
\end{tabular}


Stratigraphy-Continued Page

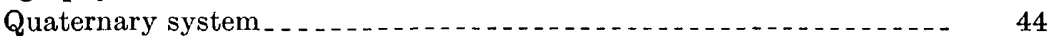

Pleistocene series _._.

Glacial drift . .

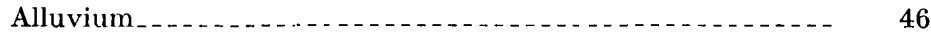

Loess _.

Structure

Folds_.

Joints_._.

Faults__._.

Economic geology

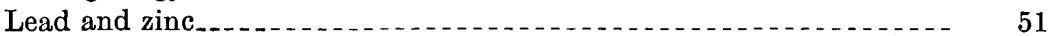

History and production $\ldots \ldots \ldots 1$

Joint-controlled deposits__._.

Pitch-and-flat deposits

Mineralogy of deposits

Stratigraphic and structural controls__._.

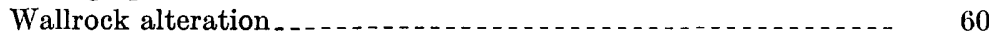

Guides to ore 61

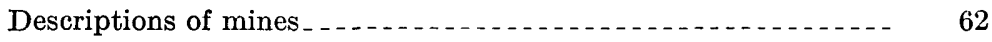

Nonmetallic deposits_._._. 63

Dolomite and limestone.

Clay

Sand and gravel

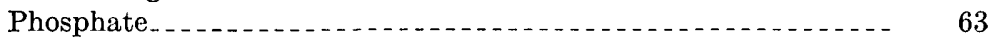

Ground water.

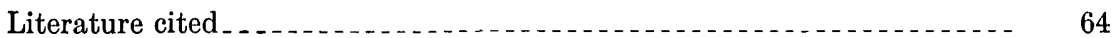

Records of drill holes

Index

\section{ILLUSTRATIONS}

[Plates are in pocket]

Plate 1. Geologic map of the Dubuque South quadrangle.

2. Map showing location of physiographic features and selected geologic occurrences in the Dubuque South quadrangle.

3. Stratigraphic section of rocks of Ordovician and Silurian age.

4. Diagrammatic section showing characteristic forms and stratigraphic' position of gash-vein and pitch-and-flat deposits.

5. Map and sections of the East Lockey Drybone mine.

6. Map and sections of the West Lockey Drybone mine.

7. Map and sections of the Royce and Frost mine.

FIGURe 1. Index maps showing location of the Wisconsin-Illinois-Iowa zinc-lead district and the Dubuque South quadrangle ...--

2. Map of Kemling Cave.

3. Photomicrograph of cherty unit of Galena dolomite......

4. Photomicrograph of Galena dolomite showing gradational contact of fine-grained limestone and crystalline dolomite.

5. Photomicrograph of Galena dolomite showing gradational contact of fine-grained limestone and chert. 
Figure 6. Map showing thickness of Maquoketa shale

7. Photomicrograph of Neda member of Maquoketa shale showing limonite oolite with quartz nucleus .................

8. Photomicrograph of Neda member of Maquoteka shale showing leached and collapsed oolites.........................

9. Cross section showing stratigraphic relation between Maquoketa shale and Edgewood dolomite

11. Outcrop of Edgewood dolomite showing wavy-bedded shaly dolomite of the Mosalem member. . . . . .

12. Outcrop of Edgewood dolomite showing massive-bedded dolomite of the Tete des Morts member

13. Photomicrograph showing detrital dolomite and phosphatic nodules of "collophane" from basal Edgewood dolomite...

14. Contact of Hopkinton dolomite and Kankakee formation.---

15. Contact of Kankakee formation and Edgewood dolomite...-

16. Silicified Catenipora cf. C. huronensis from Hopkinton dolomite-

17. Diagram showing: $A$, strikes of 460 joints in rocks of Ordovician age; $B$, strikes of 108 joints in rocks of Silurian age.

18. Index map showing location of holes drilled in the Dubuque South quadrangle for the Geological Survey in 1955....--

\section{TABLE}

TABLE 1. Reported production of galena from gash veins in the Dubuque South quadrangle. 
$-\infty$ 


\title{
GEOLOGY OF PARTS OF THE UPPER MISSISSIPPI VALLEY ZINC-LEAD DISTRICT
}

\section{GEOLOGY OF THE DUBUQUE SOUTH QUADRANGLE, IOWA-ILLINOIS}

\author{
By C. Ervin Brown and Jesse W. Wentrow
}

\section{ABSTRACT}

The Dubuque South quadrangle in the southwestern part of the WisconsinIllinois-Towa zinc-lead district is an area of 52 square miles in Iowa and 3 square miles in Illinois. The Mississippi River flows through the area and Silurian rocks form a prominent cuesta in the southern part of the quadrangle. The topography generally is in the early maturity stage of erosion and maximum relief is about 590 feet.

The rocks exposed in the Dubuque South quadrangle range in age from Middle Ordovician to Middle Silurian. Rocks of Early Ordovician and Late Cambrian age are penetrated by deep wells in the city of Dubuque. The oldest exposed rocks in the Dubuque South quadrangle are those of the cherty unit of the Galena dolomite, which crop out mainly in the bluffs along the Mississippi River. The Galena averages 230 feet in thickness and is nearly equally divided into a lower cherty unit and an upper noncherty unit.

The Maquoketa shale of Late Ordovician age is $\mathbf{1 1 4}$ to 250 feet thick and apparently overlies the Galena dolomite conformably. The Maquoketa shale is divided into three lithologic units. They are, in ascending order: the brown shaly unit, the Brainard member, and the Neda member. The Neda member occurs in the Dubuque South quadrangle at the western part of the Niagaran escarpment where the Neda is as much as 5 feet thick. It is composed of grayish-red shale and beds and lenses of limonite oolites.

After the deposition of the Neda member the seas regressed, and erosion of the Maquoketa shale began. The resultant erosional surface has at least $\mathbf{1 3 5}$ feet of relief in the Dubuque South quadrangle. The Edgewood dolomite of Early Silurian age disconformably overlies the Maquoketa shale and fills the irregularities of the erosion surface. Consequently, the aggregate thickness of the two units is nearly uniform.

The Edgewood dolomite comprises two members, the Tete des Morts and the Mosalem. The Mosalem member is wavy-bedded olive-gray to tan argillaceous dolomite. Locally at its base is a thin interformational conglomerate. The Tete des Morts member is massive grayish-yellow argillaceous glauconitic dolomite that forms many cliffs.

The Kankakee formation, also of Early Silurian age, overlies the Edgewood dolomite and consists of grayish-yellow dolomite and as much as 50 percent white bedded chert. Fopkinton dolomite of Middle Silurian age overlies the 
Kankakee and consists of nearly pure coralline dolomite and cherty dolomite that locally includes as much as 60 percent chert.

Much of the geologic information about the Ordovician-Silurian unconformity, Maquoketa shale, and Silurian rocks was obtained by drilling done in 1955 for the U.S. Geological Survey. Records of these holes are given at the end of the report.

The rocks in the Dubuque South quadrangle dip 18 feet per mile southsouthwest. The regional dip is interrupted by many small gentle folds and the strata are well jointed.

Mining of galena started as early as 1690 in the Dubuque South quadrangle and has continued until the present, although only a small amount has been mined since 1910. Mining of smithsonite and sphalerite started late in the 19th century and continued until 1910. Since then zinc ore has not been mined in Iowa.

Zinc and lead ore mined in Iowa was in gash-vein deposits in the Galena dolomite. These deposits are principally along eastward-trending joints which have been enlarged by solution of the wallrock in certain strata and at intersections with other joints. Mineralized rock continues along some joints for as much as 2 miles. Generally, these deposits have not been mined below the water table nor from the Galena dolomite where it is overlain by Maquoketa shale.

Pitch-and-flat deposits like those mined from the Decorah formation and the lower: part of the Galena dolomite in Wisconsin and Illinois have not been found in Iowa mainly because these formations are deeper here and have not been extensively explored by drilling. Drilling has proved that mineralized and altered rock similar to that near pitch-and-flat deposits occur in these strata in Iowa.

In Wisconsin and Illinois pitch-and-flat deposits generally occur on the flanks of folds, commonly closer to synclinal or basinal axes than to anticlinal axes. Delineation of these structures indicates more favorable areas for finding mineralized rock and is an important result of this study.

\section{INTRODUCTION}

\section{LOCATION AND ACCESSIBILITY}

The Dubuque South quadrangle includes about 52 square miles in northeastern Iowa and 3 square miles in northwestern Illinois. The area is bounded by long $90^{\circ} 37^{\prime} 30^{\prime \prime}$ and $90^{\circ} 45^{\prime} \mathrm{W}$. and lat $42^{\circ} 22^{\prime} 30^{\prime \prime}$ and $42^{\circ} 30^{\prime} \mathrm{N}$.

U.S. Highways $20,52,61,67$, and 151 converge in the quadrangle area toward Dubuque, Iowa. These highways and many county roads make all points easily accessible. The area is serviced by river barges and by four railroads: the Chicago, Burlington, and Quincy; the Chicago Great Western; the Chicago, Milwaukee, St. Paul, and Pacific; and the Illinois Central.

The quadrangle is partly included in the Upper Mississippi zinclead district, which is an irregularly shaped area mainly in southwestern Wisconsin and includes parts of northwestern Illinois and northeastern Iowa. The southwest boundary of the mining district is located arbitrarily at the outcrop of Silurian rocks and does not necessarily indicate the edge of mineralized rocks (fig. 1). 

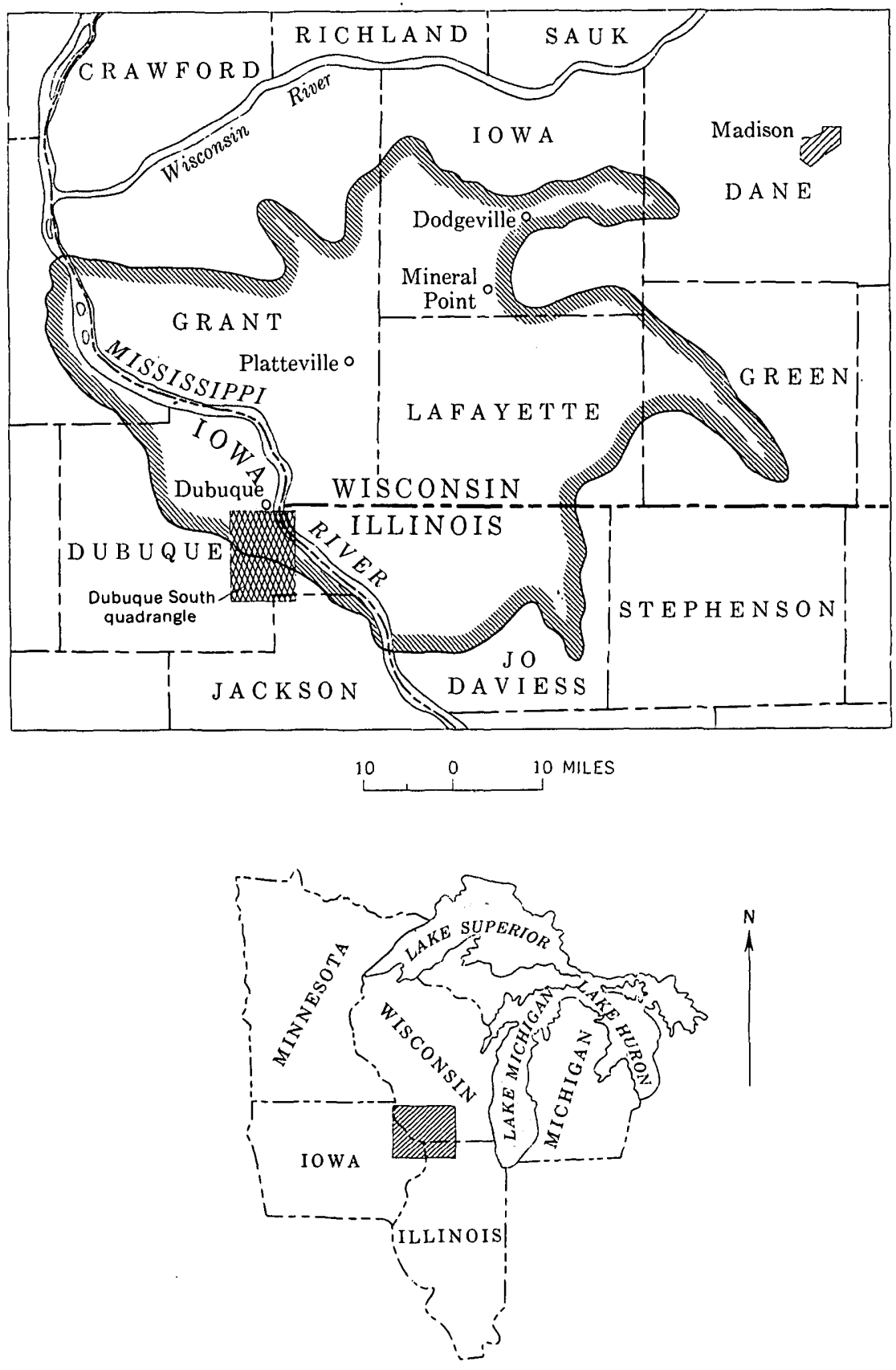

Figukv 1.-Index maps showing the location of the Wisconsin-Illinois-Iowa zinc-Iend district and the Dubuque South quadrangle. 


\section{PREVIOUS WORK}

The first geologic mapping of parts of the area included in the Dubuque South quadrangle was done by D. D. Owen in 1839 (Owen, 1840). The purpose of his work was to evaluate mineral-bearing public lands. J. D. Whitney (1858) and C. A. White (1870) described the geology of this area in their reports on the geology of Iowa, and A. G. Leonard (1897) reported on the occurrence of lead ore in Dubuque County. Samuel Calvin and H. F. Bain (1900) mapped the geology of Dubuque County. Their work includes a detailed description of mines in and near Dubuque and is the main source of information about these mines. Several of these descriptions were taken from the reports by Whitney (1858) and Leonard (1897). The southeastern part of the area included in the Dubuque South quadrangle is in Jackson County, which was mapped and the geology described by T. E. Savage in 1905 (Savage, 1906). H. F. Bain included part of this quadrangle in a structure-contour map of the zinc-lead district prepared for the U.S. Geological Survey (Bain, 1906). A. V. Heyl, Jr., and others (1945) mapped the geology and geologic structure of 3 square miles near Center Grove in the northwestern part of the quadrangle. The geologic map of the present report differs from those of earlier studies because of new information obtained during the investigations from 1954 to 1957.

\section{PURPOSE OF THE INVESTIGATION}

In 1943 the U.S. Geological Survey began a study of the stratigraphy and structure of the rocks in the Wisconsin-Illinois-Iowa zinc-lead district and their relation to the occurrence of ore so that areas possibly containing zinc- and lead-mineralized rock could be delineated. This work was mainly done in Wisconsin but investigations were also made in Iowa and Illinois. Results of the general studies have been published (Heyl and others, 1955, 1959; Agnew and others, 1956). The mapping of quadrangle areas is a continuing phase of these geologic investigations.

\section{FIELD AND IABORATORY WORK}

Twelve square miles of the northwestern part of the area was mapped in 1954 (Brown and others, 1957). The geologic data from that map were later adjusted to the topographic base used in the present report. Minor changes in the configuration of the geologic boundaries and structure have resulted from this adjustment and from geologic data obtained since 1954 (pl. 1). The fieldwork for the remainder of the quadrangle was done from April 1955 to October 1956. 
A planetable and telescopic alidade were use for surveying structure control points. Altitudes used are bench marks and supplemental altitudes established in 1953 and 1954 by the U.S. Geological Survey.

Field plotting of data in the northern half of the area was on aerial photographs taken in 1940 for the U.S. Department of Agriculture. Plotting for the remainder of the area was on aerial photographs taken in 1954 for the U.S. Geological Survey.

In addition to fieldwork, studies of subsurface geology were conducted in and near the Dubuque South quadrangle. Thirty holes were churn drilled to determine the stratigraphy of the rocks of Silurian and late Ordovician age which blanket the southern third of the quadrangle; to explore two known structures for mineralized rock; and to obtain structure control points in areas of sparse outcrops. Rock cuttings from the drill holes were studied with a binocular microscope. The logs of these holes are at the end of this report.

Also, geologic information from records of wells in this area was obtained from the files of the Iowa Geological Survey, Illinois Geological Survey, from local well drillers, and from studies of cuttings collected for the U.S. Geological Survey by well drillers.

\section{ACKNOWLEDGMENTS}

The part of the zinc-lead district in Iowa was studied in cooperation with the Iowa Geological Survey from 1951 to 1958. The Iowa Survey, directed by H. G. Hershey, contributed funds for this mapping program and furnished much geologic information from their. records of water wells.

James. Bradbury of the Illinois Geological Survey provided data concerning the geology near East Dubuque.

We acknowledge the cooperation of H. L. Landgraf, Eldon Dietz, and the Varner Well Drilling Co. for collecting samples from wells and for data from their logs of holes drilled in the Dubuque South quadrangle. The following drillers also furnished stratigraphic data from wells: Kertels Brothers, Paul Gille, Tony Beets, George Lingle, and Harry Ernster.

We also wish to thank the Iowa Grotto of the National Speleological Society for the use of their map of Kemling Oave and M. A. Melcher, president of the Wisconsin Institute of Technology, for the use of office space and laboratory facilities of the school.

We appreciate the cooperation of the following people: James Kane, for information about the mines in which he worked near the village of Key West; Monroe Royce, for locations of mine shafts in Dubuque;. Elsie Datisman, reference librarian at the Dubuque 
Carnegie-Stout Public Library, for historical data about the mines; William Byrnes, county engineer, and the Dubuque County Board of Supervisors for permission to drill holes in the county road rightsof-way; many property owners for permission to drill holes on their land; and John Carlson and Loren Ziech, for assisting in mine mapping.

\section{PHYSIOGRAPHY}

Most of the Dubuque South quadrangle is in the early maturity stage of erosion. However, the bluffs along the Mississippi River and the bluffs of the escarpment formed by rocks of Silurian age are in the youthful stage of erosion, and the dip slope of the Silurian cuesta is in the mature stage. The stream pattern is dendritic, and the transverse valley shape is closely controlled by bedrock, being generally narrow and steep walled in massive dolomite and broad and gently sloped in soft shales.

The highest altitude in the quadrangle is 1,180 to 1,190 feet near the southeast corner of sec. 25, T. 88 N., R. 2 E., and the lowest is 592 feet along the Mississippi River giving a maximum relief of 588 to 598 feet. Locally the relief is 150 to 200 feet except near the scarp of the cuesta where local relief is about 300 feet.

The most outstanding topographic features in this quadrangle are the escarpment of the cuesta formed by dolomite of Silurian age and the steep-walled, wide, flat-bottomed valley of the Mississippi River (pl. 2).

Remnants of two old erosion surfaces in this quadrangle have been described by Trowbridge (1921) who called the surface represented here by the crest of the Niagaran cuesta (pl. 2), the Dodgeville peneplain; and the surface represented by the upland in the northern half of the quadrangle, the Lancaster peneplain. Later Trowbridge (1954) called only the Lancaster surface, which has as much as 200 feet of relief, a peneplain.

There has been much controversy as to whether these are truly peneplains or structurally and lithologically controlled erosion surfaces. Martin (1916, p. 70) studied the topography in southwestern Wisconsin, which is similar and related to the topography of this quadrangle, and made the following statement:

*** all the features of the topography of western and southwestern Wisconsin are easily explained as parts of a system of cuestas in a series of gentlydipping, alternate weak and resistant, sedimentary rocks.

Although the area studied in this report is not large enough to lend strong support to either theory, the topography in the Dubuque South quadrangle is locally an expression of rock type. The cuesta of Silurian rocks has a gentle dip slope and precipitous face held up by massive beds of dolomite. Smooth and gentle slopes north of 
the cuesta are on soft Maquoketa shale, and steep-walled valleys in the northern half of the area are underlain by massive Galena dolomite.

Evidence of an old erosion surface on the uplands in the northern half of the quadrangle was found in an excavation for houses near the east edge of sec. 1, T. 88 N., R. 2 E., east-southeast of Rockdale. Here a broad stream channel is marked by chert gravel from rocks of Silurian age. This deposit is below the soil and loess and lies on heavy residual clay above the Galena dolomite. Overburden above the quarry at Horseshoe Bluff in sec. 5, T. 88 N., R. 3 E., has a similar deposit composed mainly of rounded dolomite cobbles. Both of these deposits are more than 100 feet above nearby valley bottoms.

\section{DRAINAGE}

The base level for all drainage in the Dubuque South quadrangle is the Mississippi River. In this quadrangle the river occupies onethird of the flat valley floor. The remainder of the flood plain of Recent age comprises sandbars overgrown with willow, bogs, and many sloughs. The valley walls are in the youthful stage of erosion and rise steeply as much as 245 feet above the river level.

The land surface in this area is drained into the Mississippi River mainly by Catfish Creek and its tributaries. The dip slope of the cuesta is drained into the Mississippi River by the headwaters of the Tete des Morts River and also by Lytle and Buncombe Creeks, which are tributaries to the North Fork of the Maquoketa River. Many gullies and small streams flow directly into the Mississippi River, draining the land within 2 miles of the river (pl. 2).

Most of the streams north of the escarpment are fed by springs and seeps from the Maquoketa shale, particularly from the top of the formation. The streams are all perennial where they flow on the Maquoketa shale, but downstream where they flow on Galena dolomite they are intermittent because during dry seasons water flows into the well-jointed dolomite. Water reappears downstream near the level of the Mississippi River as seeps and springs in the creek beds.

Lytle Creek and the Tete des Morts River south of the escarpment are perennial streams. The Tete des Morts River is fed by springs at the top of the Maquoketa shale, and Lytle Creek is fed by springs in dolomite of Silurian age. Although Buncombe Creek is perennial south of this area, only intermittent headwater tributaries of Buncombe Creek occur in the quadrangle.

\section{EROSIONAL HISTORY OF THE DRAINAGE SYSTEM}

The erosional history of the Mississippi River has many problematical aspects. Geologic problems involved are aptly presented by 
Trowbridge (1954); therefore, the erosional history is only briefly mentioned here.

The course of the Mississippi River was displaced as much as 100 miles northeastward in Iowa by ice of Nebraskan age (Trowbridge, 1954, p. 802). During subsequent glacial and interglacial periods the river eroded and filled its channel several times, and at one time cut a trench more than 500 feet deep. This trench has been filled with glacial outwash material to the present level of the valley floor. A well at the Star Brewing Co. in the NW1/4 sec. 30, T. $89 \mathrm{~N}$., R. 3 E., near the middle of the valley, penetrated 337 feet of gravel, sand, and silt before entering bedrock.

\section{ALIUVIAL TERRACES}

Two river terraces of Pleistocene age occur along the Mississippi River in this quadrangle (pl. 2). The top of the lower one is about 25 feet above the river. Rafferty Field in Dubuque is at this terrace level and part of East Dubuque along the base of the bluff is situated on a remnant of it. At most places these terrace remnants are beveled to the present flood plain.

The level of the upper terrace is well preserved as remnants along Catfish Creek and its tributaries and occurs as far as 3 miles upstream from the mouth. The top of this terrace occurs uniformly at a height of about 50 feet above the river surface. Remnants of it occur at this level in adjoining quadrangle areas to the east (Shaw and Trowbridge, 1916) and to the north. The remnants along Catfish Creek are composed of fine sand and silt. This terrace is not a valley-train deposit of Catfish Creek and its tributaries, because the remnants have uniform altitudes and do not occur in the valleys above where the stream profiles rise more than about 50 feet above the river surface. Calvin and Bain (1900, p. 474-475) believe that this terrace deposit is mainly the result of deposition from backwater at a time during the Pleistocene epoch when the river level was much higher than now. We concur with this opinion.

\section{INCISED MEANDERS AND ABANDONED CHANNELS}

Several examples of incised meanders can be seen along Catfish Creek and its main tributaries. We postulate that the meanders were incised early in the Pleistocene epoch when melt water from glaciers cut the trench of the Mississippi River as much as 300 feet below present river level. As a result, the base level for the tributary streams such as Catfish Creek, was correspondingly lowered. These streams had been flowing on an old erosion surface of low relief and had developed meanders; with the change in base level the streams incised their meandering courses. During this period 
Catfish Creek cut its valley floor much lower than it is now. A well at the Industrial. Chemical Co., near an abandoned mouth of Catfish Creek, NE1/4 sec. 6, T. 88 N., R. 3 E., penetrated 146 feet of gravel before entering bedrock, and a well in the valley bottom near Rockdale cemetery penetrated 70 feet of gravel without entering bedrock. Melt water from glaciers in the source areas of Catfish Creek and the Middle Fork of Catfish Creek deepened their valley.

After the meanders were incised, and probably during glacial recessions, the Mississippi River became overloaded and filled its trench. The river cut its valley walls laterally when overloading ceased. The lateral cutting at some places breached narrow divides between the river and its tributaries, which produced a new mouth for the tributary and abandonment of the cut-off part of the tributary valley. Catfish Creek has been modified in this way. The abandoned valley is in sec. 5, T. 88 N., R. 3 E. The resulting outlet at the northeast corner of sec. 6, T. 88 N., R 3 E. was later abandoned when Catfish and Granger Creeks breached the narrow divide between them near the center of the NW1/4 sec. 6 , T. $88 \mathrm{~N}$., R. 3 E. Consequently, Catfish Creek is now flowing through the former mouth of Granger Creek. This second capture probably took place shortly after the upper or backwater terrace was deposited, as these deposits have not been significantly channeled by Catfish Creek in the abandoned valley near the north edge of sec. 6. Except for the cut along the railroad, this terrace deposit effectively dams the old creek valley and may have been instrumental in the second capture of Catfish Creek.

\section{CUESTA}

The sinuous escarpment, commonly known as the Niagaran escarpment, which extends across the lower half of the Dubuque South quadrangle is the edge of a cuesta formed of dolomite of Silurian age.

The escarpment has progressed southward mainly by slumpage of large blocks at well-developed joints. These blocks slide down or settle into the slope of Maquoketa shale and occur as far as 1 mile from the escarpment.

Slumping along joints and preferential breaching of anticlines indicate the structural controls on erosion. The embayment of the escarpment in sec. 23, T. 88 N., R. 2 E., and vicinity, is a breached anticline; and the ridge trending northeastward toward Key West exists as an erosional remnant because it is in a syncline. The broad ridge trending northeastward across the southeastern part of the area is also in a syncline. The many mound remnants of this 
cuesta in the Driftless Area of Wisconsin and Illinois possibly owe their existence to their location in synclines.

\section{SINKHOLES AND CAVES}

Sinkholes are common on the dip slope of the cuesta. These are alined along joints such as those in secs. 21 and 22, T. 88 N., R. 2 E., 300 feet north of the cemetery (pl. 2). Commonly the sinkholes; are more abundant within one-half mile of the scarp edge than farther south. This is due to the lower elevation of the water table near the escarpment, which allows vadose waters to excavate and enlarge the joints. Local concentrations of sinks produce karst topography as on the top of the spur along the east edge of sec. 20, T. 88 N., R. 2 E.

Sinkholes also occur in the Galena dolomite in the NW1/4 sec. 16, T. 88 N., R. 2 E., and the SW1/4 sec. 17 , T. 88 N., R. 3 E., and are alined parallel to dominant joint directions.

Solution by ground water along joints in both the Galena dolomite and the dolomite of Silurian age has formed many caves. These caves have later been partly filled with mud and rock debris. Kemling cave (fig. 2) in the NE $1 / 4 \mathrm{NE} 1 / 4$ sec. 17 , T. 88 N., R. 3 E. has more than 2,000 feet of known passageways, which are along joints. The openings are as much as 40 feet high and 15 feet wide but eommonly are 5 feet high and 2 feet wide. One commercialized cave, Crystal Lake Cave, in the Galena dolomite is near the center of sec. 16, T. 88 N., R. 3 E., just east of the Dubuque South quadrangle. Another cave, which was explored by Lawrence Kemling, was entered at a sinkhole near the center of the W1/2 sec. 17, T. 88 N., R. 3 E. This cave extends eastward from the sinkhole to the east side of U.S. Highway 52 (James Kane, oral communication). Other small caves in the hillside and quarries south of Dodge Street in sec. 25, T. 89 N., R. 2 E. were examined during this investigation. Some of these had been explored and enlarged by early miners in search of galena deposits. Many of the caves contain stalactites, stalagmites, and banded travertine.

\section{STRATIGRAPHY}

The rocks exposed in this quadrangle are limestones, dolomites, and shales that range in age from Middle Ordovician to Middle Silurian. An erosional unconformity which has at least 135 feet of relief separates the rocks of Ordovician and Silurian age.

Cuttings of rocks older than Middle Ordovician have been examined from wells in Dubuque; but because these rocks are not exposed and have little economic importance in this quadrangle, they are discussed only briefly. 
DUBUQUE SOUTH QUADRANGLE, IOWA-ILLINOIS

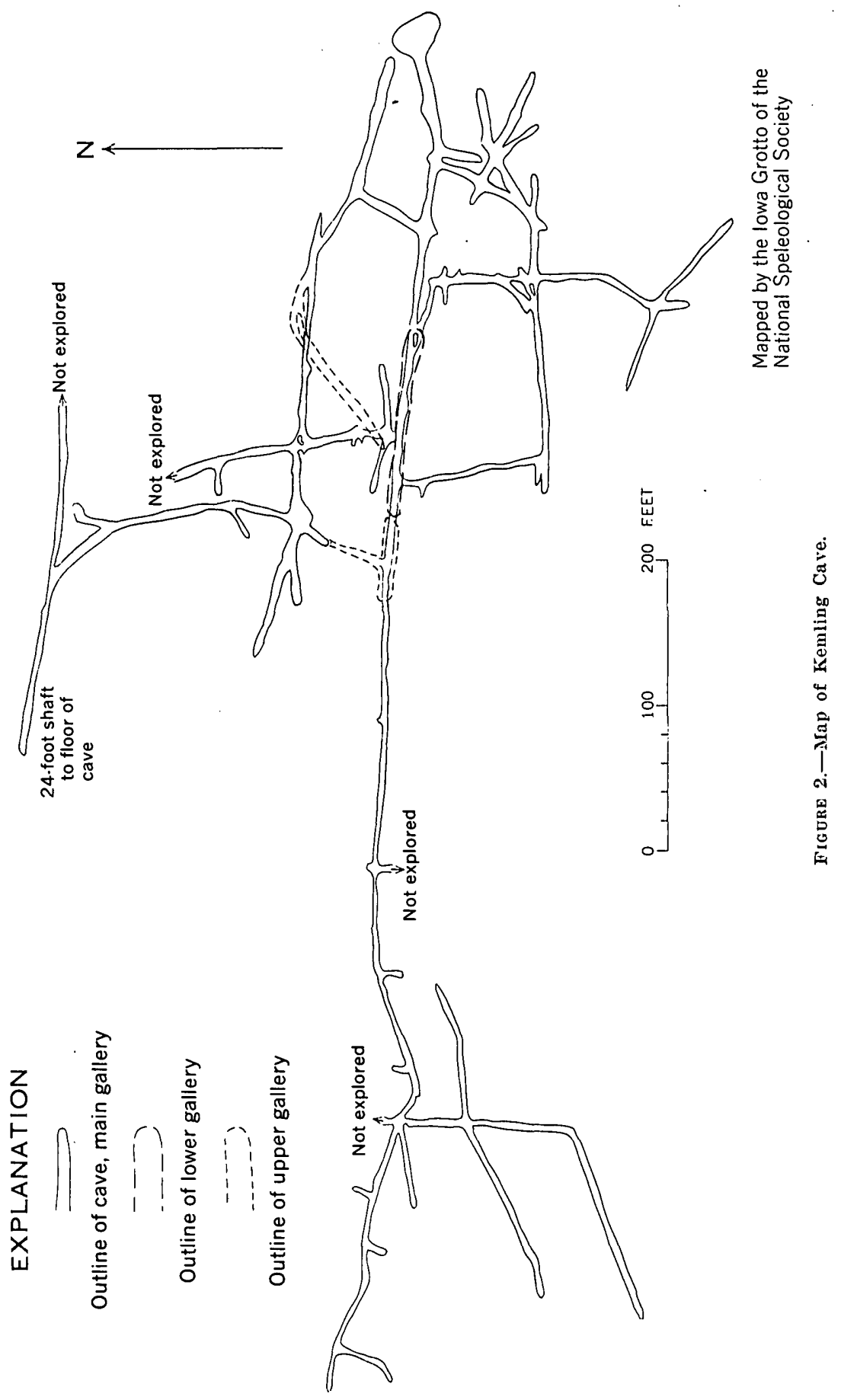


Two formations that contain mineralized rock in the upper Mississippi zinc-lead district are not exposed in the Dubuque South quadrangle, but because of their economic importance these rocks are described in detail and are shown in plate 3.

The stratigraphic subdivision of rocks as used in this report is based on lithologic differences. Color terms used in the descriptions of rocks refer to the "Rock-color Chart" prepared by the National Research Council. A systematic paleontologic study has not been made because much of the stratigraphic information from this quadrangle, as in other parts of the mining district, is from study of well cuttings in which megafossils are practically unusable. However, a paleontologic study would contribute much to the knowledge of stratigraphy in the mining district even though many fossils have been obliterated by dolomitization and recrystallization.

The regional stratigraphy of rocks of Middle Ordovician age has been described (Agnew and others, 1956); therefore discussion of these strata in this report is confined to their occurrence in the I) buque South quadrangle.

\section{PRECAMBRIAN AND CAMBRIAN SYSTEMS}

Rock of Precambrian age was penetrated in Dubuque city wells 5 and 8 at 1,165 feet and 1,180 feet, respectively, below sea level. Cuttings of this rock in well 8 were examined by geologists of the Iowa Geological Survey and apparently are from a biotite-rich granitic rock. The wells are in the SE1/4 sec. 7, T. 89 N., R. 3 E., about 2 miles north of the Dubuque South quadrangle. The well of the Fisher Ice Co. in the NW1/4 sec. 30, T. 89 N., R. 3 E., has a total depth of 1,950 feet or 1,350 feet below sea level, but it does not reach Precambrian rocks. This information indicates that the surface of the rocks of Precambrian age has local relief. Its depth below the surface of the Dubuque South quadrangle can only be approximated.

Rocks of Late Cambrian age overlie Precambrian rocks unconformably and include the following formations, in ascending order: Mount Simon sandstone, Eau Claire sandstone, Dresbach sandstone, Franconia sandstone, and Trempealeau formation. The dominant lithology is sandstone, but some siltstone and dolomite are included.

Cuttings from Upper Cambrian strata were collected from deep wells near Dubuque and were studied by the Iowa Geological Survey. 'These well records indicate that the total thickness of Upper Cambrian rocks ranges from 1,350 to 1,500 feet. 


\section{ORDOVICIAN SYSTEM}

\section{LOWER ORDOVICIAN SERTES}

PRAIRIE DU CHIEN GROUP

The Prairie du Chien group comprises arenaceous dolomite and locally sandstone, and was named by H. F. Bain (1906, p. 18) for outcrops near Prairie du Chien, Wis. It was observed in the Dubuque South quadrangle as cuttings from the deep wells in Dubuque. The Prairie du Chien, because it has an uneven upper surface, ranges in thickness from 120 feet in the well of the Maizewood Insulation Co. to 300 feet in the well of the Trausch Bakery. Both wells are in the SE1/4 sec. 25 , T. 89 N., R. 2 E. This irregular: surface is generally believed to be an erosional unconformity, but recent studies by A. E. Flint (1956) suggest that in the mining district this contact represents sand deposition on a sea floor made uneven by differential compaction of lime muds over rigid reef. masses. The relief of this surface was accentuated by subsequent intrastratal solution and slumping in the interreef zones (Flint, $1956)$.

\section{MIDDLE ORDOVICIAN SERLES}

ST. PETER SANDSTONE

The St. Peter sandstone overlies the Prairie du Chien group. It is commonly 40 to 50 feet thick and is composed of rounded and frosted quartz grains. Local sections of the St. Peter are as much as 200 feet thick; these are fillings of the depressions in the top of the Prairie du Chien group.

\section{PLATTEVILLE FORMATION}

The Platteville formation was named by Bain (1905, p. 18-19) for outcrops near Platteville, Wis. In the Dubuque South quadrangle only six holes are known to have been drilled through the Platteville. Cuttings taken from these holes show that the formation has an average thickness of 62 feet. This formation is described in detail because it is commonly mineralized in other parts of the zinc-lead district.

\section{GLENWOOD SHATE MEMBER}

The Glenwood shale member was named by Calvin (1906a, p. 60-61, 75) for outcrops in Glenwood Township, Winneshiek County, Iowa. The Glenwood conformably overlies and is transitional to the St. Peter sandstone. It is 2 to 4 feet thick in the Dubuque South quadrangle and consists of yellowish-green dolomitic shale and argillaceous quartz sandstone. 
The Pecatonica dolomite member overlies the Glenwood shale and was named by Hershey (1894, p. 175) for outcrops along the Pecatonica River in northern Illinois.

The $\log$ of the well at the Dubuque Municipal Airport in the NE1/4. sec. 27, 'T. 88 N., R. 2 E., shows 35 feet of Pecatonica member; a prospect hole that was drilled to the St. Peter sandstone in the SE1/4 sec. 33, T. 89 N., R. 2 E., penetrated 28 feet of Pecatonica strata. The Pecatonica is a sugary-textured grayish-brown dolomite containing small phosphatic nodules and grains of quartz sand near its base.

MCGREGOR LIMESTONE MEMBER

The McGregor limestone member overlies the Pecatonica and was named by Kay (1935a, p. 286-287) for exposures near McGregor, Iowa. The McGregor at the type locality, is thin-bedded light-olivegray fine-grained fossiliferous limestone with many shale partings. Well logs from the Dubuque South quadrangle indicate a thickness of 25 to 30 feet for the McGregor. Locally in the mining district the McGregor member is dolomite because of alteration by mineralizing solutions.

\section{QUIMBYS MILL MEMBER}

The Quimbys Mill member overlies the McGregor limestone member and was named for a quarry exposure at Quimbys Mill, Lafayette County, Wis. (Agnew and Heyl, 1946, p. 1585). The Quimbys Mill member comprises pale-brown sugary-textured dolomite and brown lithographic limestone with dark-brown shale partings. The base is marked by a few inches of spotted dark-brown shale. The limestone rings when struck with a hammer and breaks with conchoidal fracture. It is locally known as the glass rock. The Quimbys Mill member has been seen in outcrops in Iowa only near Spechts Ferry, Dubuque County, where only the basal shale exists. In the Dubuque South quadrangle the Quimbys Mill member as much as 2 feet thick has been found in diamond-drill cores from holes drilled in the SE1/4 sec. 33, T. 89 N., R. 2 E., by the U.S. Bureau of Mines (Lincoln, 1948). Cuttings from a hole drilled for the U.S. Geological Survey (p. 75) in the SE1/4 sec. 16, T. 88 N., R. 3 E., less than 1 mile from the east edge of the Dubuque South quadrangle, showed 3 to 4 feet of Quimbys Mill member; drilling for the U.S. Geological Survey in an area 7 to 8 miles east of the southeast corner of this quadrangle showed 6 to 11 feet of Quimbys Mill (Agnew and others, 1953). The Quimbys Mill member thickens eastward in the mining district and is 18 feet thick near Shullsburg, Wis. The Dubuque South quadrangle is near the thinning western edge of this member. 


\section{DECORAF FORMATION}

The Decorah formation was named by Calvin (1906a, p. 60, 84) for exposures near Decorah, Iowa, where it is predominantly green shale. Kay (1928, p. 16) divided the Decorah into three members, which are recognized in the mining district and have been studied in the Dubuque South quadrangle in cuttings and cores from drill holes. Records of holes show an average thickness of 46 feet for the Decorah formation, which consists of shaly limestone, dolomitic limestone, and shale. Locally, mineralizing solutions altered the strata by leaching the carbonate, and consequently caused thinning of the beds and compaction of the shaly insolubles. Dolomitized and silicified limestone are common results of alteration in these strata throughout much of the mineralized district, and have been noted in one drill hole in this quadrangle, (see "Wallrock alteration," p. 60).

\section{SPECHTS FERRY SHALE MEMBER}

The Spechts Ferry shale member overlying the Quimbys Mill was named by Kay (1928) for an outcrop in a ravine at Spechts Ferry, Dubuque County, Iowa. At the type section this member comprises 8.8 feet of bluish-green soft shale, lenses and thin beds of greenishgray dense fossiliferous limestone, and near the base a layer of bentonite a few inches thick. This member thins eastward and pinches out near the east edge of the district. In the Dubuque South quadrangle cuttings from drill holes show that the rock of the Spechts Ferry shale member is the same as at the type section, and the thickness is uniformly 9 to 10 feet.

\section{GUTTENBERG LIMESTONE MEMBER}

The Guttenberg limestone member overlies the Spechts Ferry shale member and was named by Kay (1928) for outcrops near Guttenberg, Iowa, where it consists of $151 / 2$ feet of fine-grained wavy bedded light-brown limestone with carbonaceous shale partings. The Guttenberg is 16 feet thick in the Dubuque South quadrangle and the rock is similar to that of the type section. Nodular chert is sparse and small phosphatic nodules are common in the basal bed of the Guttenberg. Fragments of these have been seen in cuttings from churn-drill holes in this quadrangle. The Guttenberg limestone member near mineralized zones is commonly altered by solution of the carbonate and compaction of the shaly residue (see "Wallrock alteration," p. 60). As a result, the Guttenberg locally is thinned. This solution thinning could easily be mistaken for stratigraphic thinning except for the presence of lead and zinc sulfide attesting to its secondary origin. The Guttenberg member is 
locally known as the oil rock because it is notably petroliferous where dissolved and compacted to a shaly residue.

ION DOLOMITE MEMBER

Kay (1928, p. 16) named the Ion dolomite member for outcrops near Ion, Allamakee County, Iowa. In the mining district the contact between the Ion and the Guttenberg limestone member is transitional. The transitional zone is about 2 feet thick and grades from fine-grained pale-brown limestone of the Guttenberg to mediumgrained olive-gray limestone and dolomite of the Ion member. A zone of bryozoan fossils, Prasopora, occurs at the top of the Ion dolomite.

In the Dubuque South quadrangle the Ion member is generally light-olive-gray limestone and has green shale partings, but locally the upper part is dolomite or dolomitic limestone which may be due either to alteration related to mineralization or to regional dolomitization.

The Ion dolomite member is 20 to 21 feet thick in this quadrangle as well as in much of the mining district. The upper 13 feet is called the gray beds by local miners and drillers, and the lower 7 to 8 feet is called the blue beds. This separation is possible because in the mining district the lower 7 to 8 feet of the Ion member contains more green shale partings than the upper part.

Alteration related to mineralization affects the Ion dolomite member by carbonate solution and compaction of the shale and by intergranular corrosion producing a friable mass of fine dolomite grains.

\section{GALENA DOLOMITE}

Hall (1851, p. 146) named the Galena dolomite for exposures near Galena, Jo Daviess County, Ill. At the type locality the Galena strata are grayish-yellow to grayish-orange medium- to thick-bedded crystalline or granular porous dolomite. The lower half of the Galena dolomite contains much chert as nodules and nodular bands along and parallel to bedding. Weathered outcrops of Galena resemble the surface of a sponge because of vugs produced by selective solution at porous spots in the rock.

Galena dolomite in the mining district has been divided into the cherty and noncherty units, a useful division for subsurface as well as outcrop studies. The standard stratigraphic division of the Galena is, in ascending order: Prosser cherty member, Stewartville massive member, and Dubuque shaly member. However, in the mining district, only the Dubuque member is a discrete unit. The other two do not have well-defined stratigraphic boundaries. The Cummingsville member of Weiss (1955) found in southeastern Minnesota is not here. 
Receptaculites oweni Hall is a common fossil in the Galena dolomite and in the mining district occurs in three zones known as the upper, middle, and lower Receptaculites zones.

Galena strata are the oldest rocks exposed in the Dubuque South quadrangle. The Galena dolomite forms cliff's along the Mississippi River and its tributaries and is 225 to 233 feet thick. The upper 190 feet are exposed in this quadrangle.

Bentonitic seams such as those in some other parts of the mining district (Agnew and others, 1956, p. 297) have not been found in the Dubuque South quadrangle. Nevertheless, near the stratigraphic position of these seams of bentonite are thin yellowish-gray silty dolomite layers which may be bentonitic.

CHERTY UNIT

The cherty unit in the Dubuque South quadrangle is the lower 110 to 115 feet of the Galena dolomite and is part of the Prosser cherty member. This unit has abundant chert in certain strata, and locally may be subdivided into usable zones based generally on the presence or absence of chert and Receptaculites. These zones have letter designations $A$ through $D$ (pl. 3), in descending order (Agnew and others, 1956, p. 296-297). They may be roughly correlated throughout the mining district. Zone $A$ and the upper few feet of zone $B$ are exposed at many places in the bluffs along the Mississippi River, and zones $C$ and $D$ have been identified by the amount of chert in drill cuttings from holes in the Dubuque South quadrangle.

Zone $D$ comprises about 10 feet of light-brown crystalline dolomite containing no chert bands. It is transitional to the underlying Ion dolomite member of the Decorah formation. Zone $C$ is about 15 feet thick and contains abundant chert. Zone $B$, which includes most of the lower Receptaculites zone, is about 15 feet thick and has few chert nodules or bands.

Zone $A$ is the upper 75 feet of the cherty unit and contains the middle Receptaculites zone. The rock is medium-bedded porous crystalline grayish-orange dolomite and has many nodular bands of chert. Interbedded with the porous dolomite are beds as much as 7 feet thick of dense yellowish-gray smooth-weathering dolomite containing chert in regular bands. Thin sections of this rock show a mosaic of interlocked $0.1-\mathrm{mm}$ anhedral dolomite grains and as much as 10 percent angular quartz silt (fig. 3). Quartz silt is rare in the vuggy crystalline dolomite beds in the cherty unit. These impure dolomite strata are very distinctive in outcrop because of their smooth, weathered surfaces. A few of them can be traced for several miles. The most distinctive bed of this lithology is exposed in the Illinois Central Railroad cut at the southeast tip of fractional 


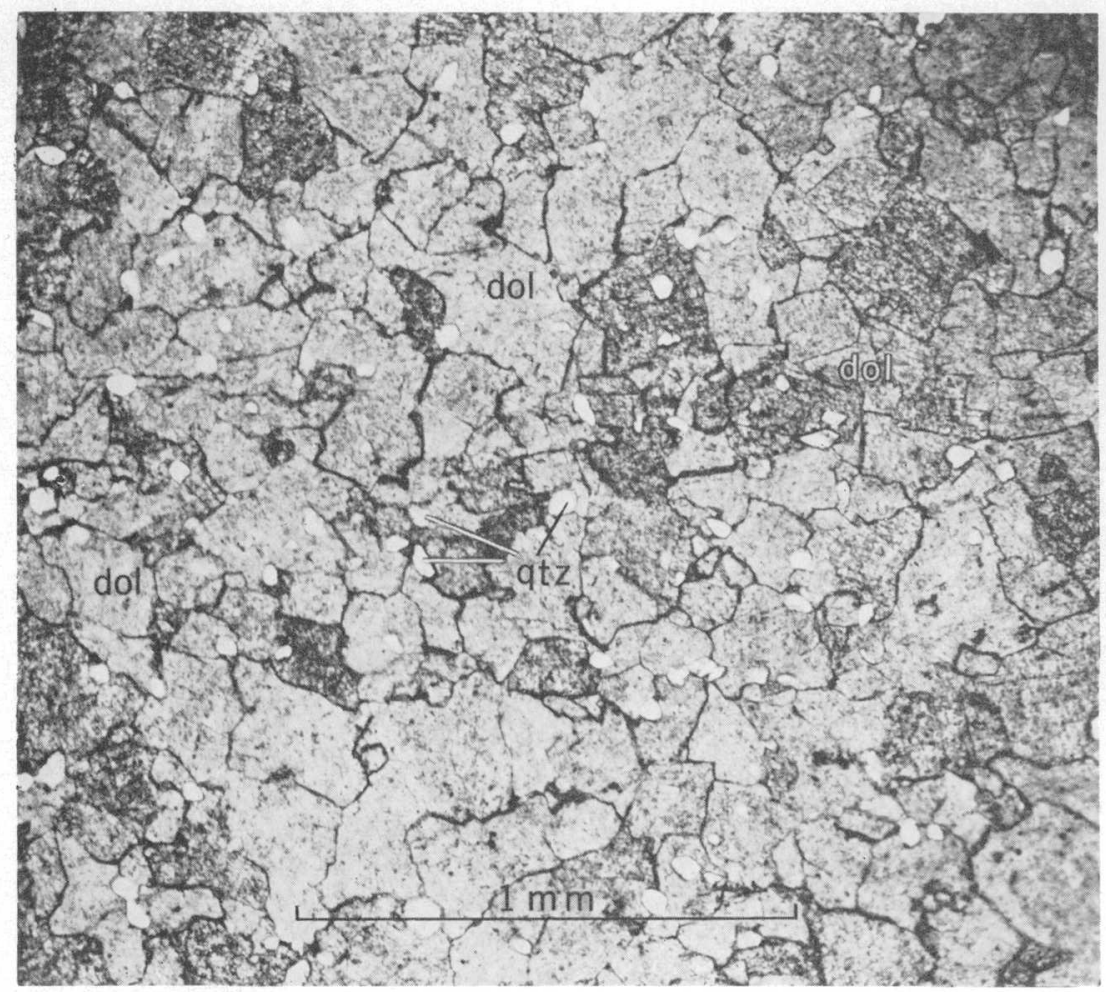

Figure 3.-Photomicrograph showing quartz silt in mosaic of dolomite grains from eherty unit of the Galena dolomite from quarry along Valeria St., Dubuque, Iowa. Plain light; $(d o l)$ dolomite, $(q t z)$ quartz.

sec. 31 , T. 89 N., R. 3 E. The bed is 7 feet thick, and here its base is 47 feet below the top of the cherty unit. This bed is conspicuous because it contrasts sharply with the adjacent vuggy grayish-orange crystalline dolomite.

The upper 35 feet of zone $A$ contains much chert as scattered nodules, has fewer contrasting beds, and is more irregularly bedded than the lower part. Thin fucoidal beds are common in zone $A$ and appear as mottled yellowish-gray silty dolomite layers.

The top of the cherty unit is marked by two discontinuous bands of chert nodules which are separated from the main cherty unit by about 5 feet of noncherty dolomite. Chert from these bands is not recovered in cuttings from all drill holes, consequently the highest chert in cuttings might be as much as 5 feet below the actual top of the cherty unit.

Fossiliferous fine-grained pale-yellowish-brown limestone mottled with patches of yellowish-brown granular dolomite occurs locally in the cherty unit of the Galena dolomite in the Dubuque South quadrangle. Generally only the lower 40 to 50 feet of the cherty 
unit is limestone at these local places (pl. 3), but outcrops in the small valley north of the Dubuque South quadrangle in sec. $20 \mathrm{~T}$. 29 N., R. 2 W., show limestone throughout the cherty unit. Plate 2 shows the known occurrences of limestone in the Galena dolomite in the Dubuque South quadrangle.

Some of these limestone areas in the mining district apparently are surrounded by dolomite, and hence have been called limestone islands (Agnew and others, 1956, p. 299) ; but possibly some of them are the ends of lobate fingers extending southeastward from limestone facies of the lower part of the Galena dolomite in northeastern Iowa.

The contact between dolomite and limestone is not consistently at the same stratigraphic position. The contact zone has similar rocks regardless of stratigraphic position. A rock description of a typical section in ascending order from limestone to dolomite is (a) thinbedded sublithographic fossiliferous mottled yellowish-gray to lightolive-gray limestone containing small patches of calcite-cemented granular yellowish-brown dolomite; (b) gradation into about 4 feet of dark-yellowish-brown dolomitic limestone composed dominantly of fine dolomite crystals cemented with calcite and mottled with small patches of light-olive-gray limestone and dark-grayish-orange granular dolomite (fig. 4); and (c) normal grayish-yellow finely crystalline dolomite.

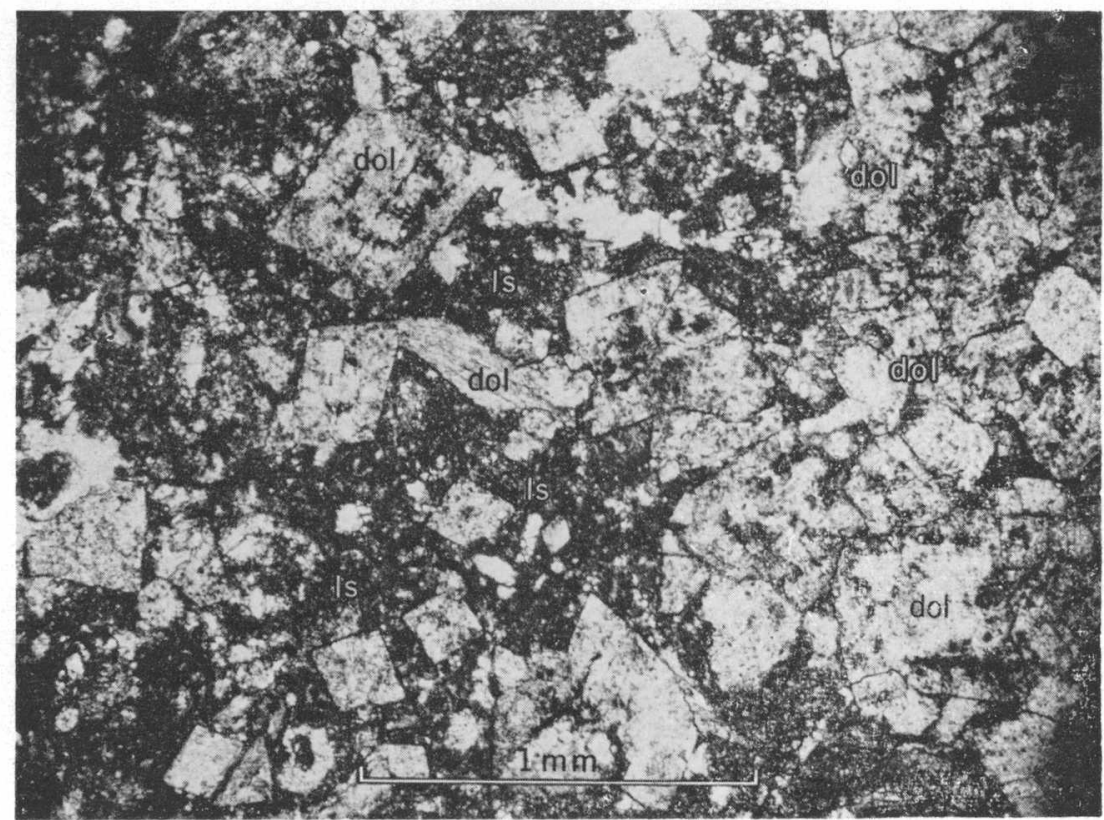

FIGURE 4.-Photomicrograph of Galena dolomite from the NE $1 / 4$ sec. 20, T. 29 N., R. 2 W.. showing gradational contact of fine-grained limestone $(78)$ and crystalline dolomite (dol). Plain light. 


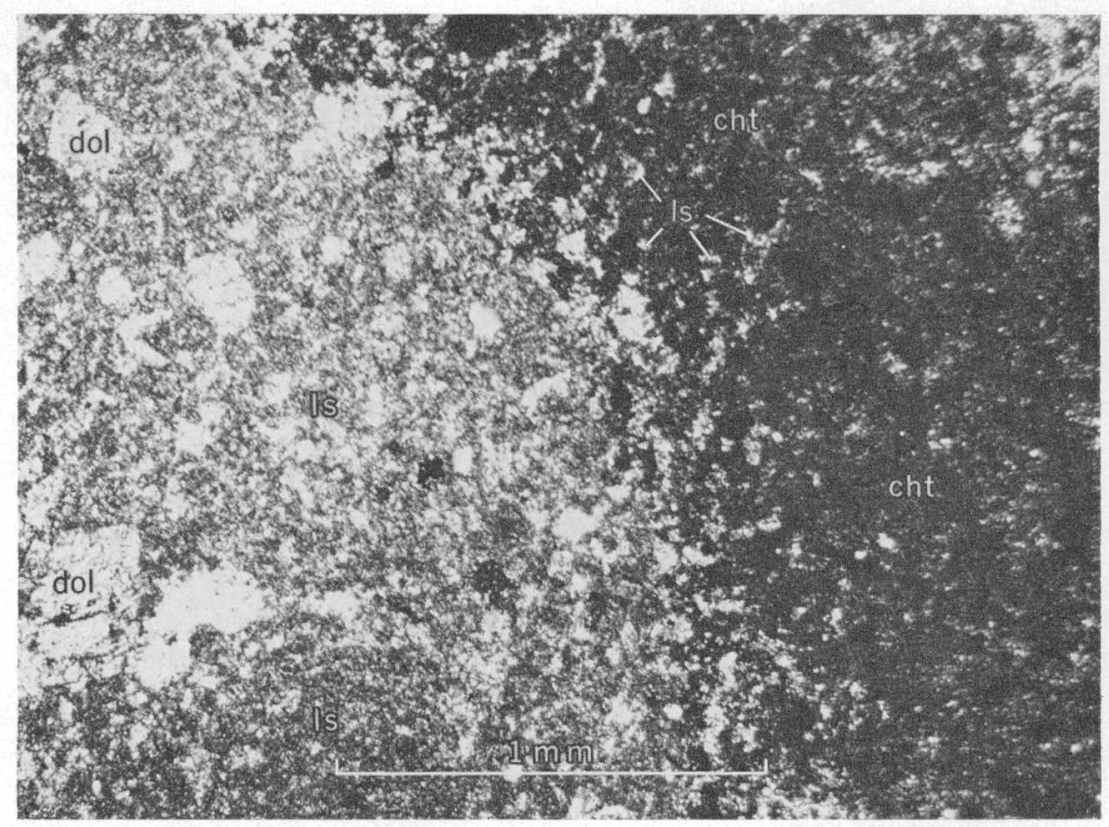

Figure 5.- Photomicrograph of Galena dolomite from the same locality as figure 4, showing gradational contact of fine-grained limestone $(l s)$ and chert $(c h t)$. Crossed nicols.

The chert in the cherty unit is nodular or in irregular bands and grades from yellowish gray to light bluish gray. Fossil molds and brownish-gray fossil markings are common and give the chert a finely mottled appearance. Near mineralized zones the chert is selectively mineralized with microscopic disseminated grains of iron sulfide, coloring it bluish gray. Commonly it is altered to powdery white secondary tripoli, which appears at most places as a thin rind on the nodules.

Chert occurs in limestone as well as in dolomite. Where unaltered chert is in contact with limestone, it is transitional in color and texture to the limestone (fig. 5), and the contact can be found only by testing the hardness. However, where chert is in contact with dolomite it commonly has a powdery white rind and the nodules are loosely attached.

The powdery rind of silica was possibly produced either by solution of the limestone in the gradational contact zone during dolomitization, leaving a silica residue, or by crystallization and coarsening of carbonate grain size as the included limestone was dolomitized, causing disintegration of the interstitial silica framework. These suppositions are made assuming that this dolomite is not a primary sediment. We have not found conclusive evidence for this assumption. 
Chert occurs only along bedding surfaces or as discrete nodules distributed parallel to bedding, and not along joints or other secondary structural features. We believe that the original silica of the chert was deposited as colloidal silica with the carbonate sediment. During induration of the carbonate sediment, the colloidal silica bled out of the enclosing mud and segregated as discontinuous globules along bedding surfaces. Replaced fossils, inclusions of limestone, and texture similar to that of the limestone attest to the epigenetic nature of the chert. The even distribution of nodular chert over most of the mining district, and bedding surfaces as loci for deposition, as against control of deposition by secondary structural features, are evidence that this type of silica was probably deposited with the carbonate sediment and segregated later into its present nodular form.

\section{NONCHERTY UNIT}

The noncherty unit of the Galena dolomite includes part of the Prosser cherty member and all of the Stewartville massive and Dubuque shaly members. The lower 78 feet of the noncherty unit is massive-bedded grayish-yellow and grayish-orange fine- to medium-grained porous crystalline dolomite which weathers to a vuggy spongelike surface. A 2-foot bed 16 to 18 feet above the base of the noncherty unit weathers smooth and has fine darkbrown argillaceous partings which in some outcrops allows the bed to disintegrate and form a reentrant. This bed is well-exposed in a roadcut in the $\mathrm{SW} 1 / 4 \mathrm{NE} 1 / 4$ sec. 7 , T. $88 \mathrm{~N}$., R. 3 E., and in the abandoned quarry at the northwest end of Horseshoe Bluff, sec. 5, T. 88 N., R. 3 E.

The upper Receptaculites zone is about 15 to 20 feet thick and its base is 35 feet above the top of the cherty unit, although rare Receptaculites individuals can be found only 25 feet above the top of the unit. Gastropods are common in a 5-foot zone underlying the upper Receptaculites zone. Two conspicuous reentrants are typical in weathered outcrops and aid in using the upper Receptaculites zone for structural control points. The base of the lower reentrant is 5 feet above the base of the Receptaculites zone and comprises 4 feet of 0.5 - to 1-foot beds which weather more readily than the massive beds above and below. Receptaculites are common in the beds forming this reentrant. The upper reentrant is 1 to 2 feet below the top of the Receptaculites zone and is only about 0.3 foot high. It is produced by the weathering of a thin bed which is separated from the adjacent strata by well-developed bedding surfaces. The reentrants are conspicuous in bluff exposures.

The Dubuque shaly member was named by Sardeson (1907, p. 193) for exposures on the campus of Loras Academy in Dubuque, 
Iowa. The Dubuque is the upper 40 feet of the noncherty unit and consists of earthy grayish-yellow to yellowish-orange fine-grained finely porous dolomite beds with intercalated grayish-yellow and pale-brown silty dolomitic shale layers as much as 0.3 foot thick. Rock cuttings of unoxidized Dubuque strata below the water table are more gray than similar rock above the water table.

The basal 6 feet of the Dubuque shaly member is gradational with the underlying Stewartville massive member in that the dolomite is crystalline, porous, and more massive than the rest of the Dubuque. The shale layers, which are typical of the Dubuque shaly member, occur between these beds. The basal contact of the Dubuque has been designated at different stratigraphic positions by previous workers. Sardeson (1907, p. 193) described the Dubuque as beds containing Lingula iowensis and overlying the caprock, the uppermost massive bed in the Galena dolomite. Kay (1935b, p. 571) restricted the member to the upper 30 feet of the Galena dolomite. Because shale partings are the most distinguishing lithologic features of the Dubuque member, we agree with Willman and Reynolds (1947, p. 9) who name the base as the lowermost shale bed. The basal shale in the Dubuque South quadrangle is 1 to 2 inches thick and forms a distinct reentrant, as do the other shale partings in the Dubuque.

The sequence of beds separated by thin layers and included from 3.4 to 9.0 feet above the basal shale is the caprock unit of Flint and Brown (1955), and is easily recognized in outcrops. In ascending order the beds are 1.7, 0.5 , and 3.2 feet thick. The 3.2-foot bed is the caprock of the first mineralized opening of the gash-vein deposits (pl. 3). We have given a 2 -foot layer 2 to 4 feet above the caprock the field designation "ledgeformer," because it is the uppermost bed in the Galena dolomite that commonly crops out. The beds above this are all less than 1 foot thick and are separated by shale layers.

The lower 20 feet of the Dubuque shaly member is planar bedded and breaks out in even slabs. The upper 20 feet of the Dubuque shaly member is very nodular, wavy bedded, and commonly contains large vugs. This zone is more argillaceous than the underlying even-bedded strata, and the vugs commonly contain crystals of calcite, pyrite, and less commonly sphalerite, barite, and galena.

\section{UPPER ORDOVICIAN SERIES}

MAQUOKETA SHALE

The Maquoketa shale was named by C. A. White $(1870$, p. 180 182) for outcrops along the Little Maquoketa River in Dubuque County, 6 to 7 miles west of the northwest corner of the Dubuque 
South quadrangle. White described the shale as "bluish and brownish shales which weather into a tenaceous clay."

Calvin (1906a, p. 94-109) named and described four formations in the Maquoketa shale group of Winneshiek County; in ascending order, the Elgin shaly limestone, Clermont shale, Fort Atkinson limestone, and Brainard shale.

H. S. Ladd also studied the Maquoketa shale in Iowa. He reported $(1929$, p. 329-349) that from the type locality northwestward the Maquoketa shale contains progressively more carbonate rocks and southeastward more argillaceous rocks. Strata northwest of the type locality, described by Calvin (1906a), were recognized by Ladd but were called members instead of formations. Consequently the Maquoketa shale has been considered a formation instead of a group.

We have recognized correlatives of the Brainard shale and the Elgin shaly limestone of Calvin in the Dubuque South quadrangle; in addition, as much as 5 feet of the overlying iron-bearing Neda formation of other areas occurs in the Dubuque South quadrangle. The Neda is here considered a member of the Maquoketa shale because it is too thin to be mapped as a formation and is faunally (Savage and Ross, 1916) and lithologically related to the Maquoketa rather than to the overlying Edgewood dolomite.

The Maquoketa shale in the Dubuque South quadrangle occurs on most of the divides north of the Niagaran cuesta and forms the smooth slopes that extend downhill from the escarpment of the cuesta. It also underlies the valley of the Tete des Morts River in the southeast corner of the quadrangle. The formation has few outcrops, and therefore its approximate boundary as shown at most places on plate 1 was calculated from the structural contours and topography, assuming the topography to nearly represent the bedrock surface. This is a valid assumption except where surficial deposits are abnormally thick.

Drilling in and near the Dubuque South quadrangle in 1955 (see p. 68) provided subsurface information about the stratigraphy of the Maquoketa shale and the nature of the Silurian-Ordovician unconformity. Some conclusions reached as a result of this drilling follow :

1. Post-Maquoketa erosion produced a surface on the Maquoketa shale having a relief of about 135 feet in the Dubuque South quadrangle.

2. The total thickness of the Maquoketa shale in this quadrangle ranges from 114 to about 250 feet (fig. 6).

3. The strata of the Maquoketa shale are discontinuous locally, and only approximate correlations can be made. 


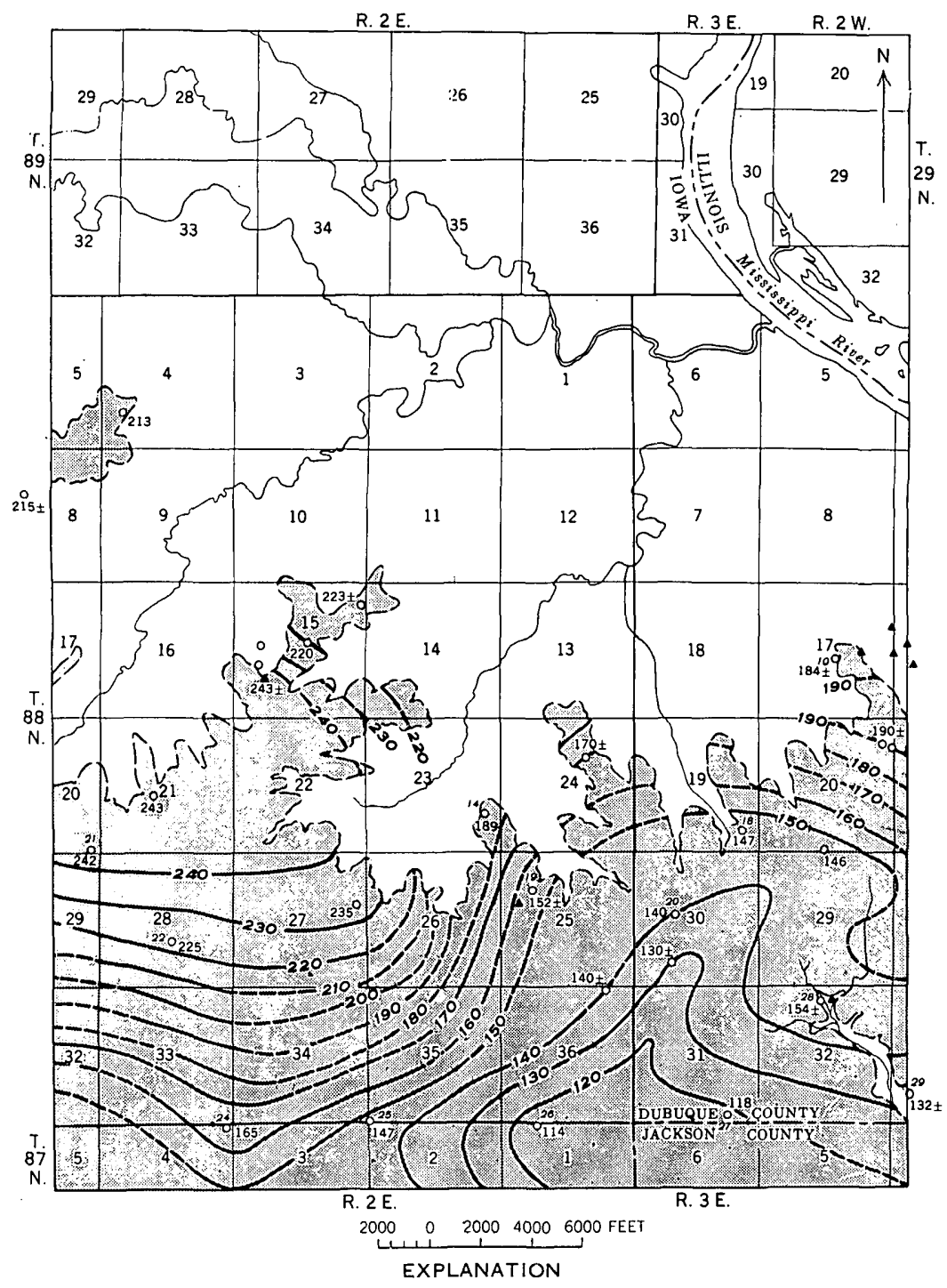

\section{0}

Area covered by rocks of Silurian age

$$
{ }^{24} \mathrm{O}^{165}
$$

Drill hole, showing Maquoketa shale thickness, in feet

Symbol without footage is supplemental drill hole for determining thickness at nearby outcrop. Slant number identifies U.S. Geologica/ Survey drill hole record in text
Isopach line

Dashed where approximate; isopach interval, 10 feet

$$
243 \pm
$$

Outcrop, showing Maquoketa shale thickness, in feet

Symbol without footage is supplemental outcrop for deiermining thickness at nearby outcrop or drill. hole

Figure 6.-Map showing thickness of Maquoketa shale in the Dubuque South quadrangle. 
4. The Maquoketa shale has three identifiable rock units-a lower unit of indurated brown shale and dolomite; a middle unit, the Brainard member, of green, blue, or gray dolomitic soft shale, which has fossiliferous dolomite beds at the top; and a thin upper unit, the Neda member, of oolitic iron-bearing shaly beds.

5. The Neda is found only where the Maquoketa has a maximum thickness.

BROWN SHALY UNIT

The lower unit of the Maquoketa shale, in this report called the brown shaly unit, correlates faunally with the Elgin shaly limestone of Calvin (1906a) and comprises grayish-brown and yellowishbrown interlayered shale, siltstone, and argillaceous dolomite. The rocks are very fossiliferous and in the lower part contain a varied phosphatic depauperate fauna. This is the depauperate zone described by Ladd (1929, p. 371-375) as a zone of "universal smallness." "Depauperate" as used in this report refers to the small size of the individual fossils and is being used as a stratigraphic term without genetic implications. The shale contains abundant carbon films of graptolites, which are mainly Diplograptus peosta.

The dolomite commonly has 3- to 5-inch individuals of Michelinoceras (formerly Orthoceras) sociale. Many of the dolomite and siltstone beds have a strong petroliferous odor when broken, and produce a black oil scum on the sludge when drilled.

The brown shaly unit can be identified in rock cuttings from drill holes and averages 41 feet in thickness, ranging from 35 to 51 feet. It is thinnest in the southeastern part of the quadrangle in secs. 31 , 32 , and 33, T. 88 N., R. 3 E., and in the south half of sec. 1, T. 87 N., R. 2 E. The brown shaly unit is also thin in secs. 4 and 5, T. 88 N., R. 2 E. The thickest section known is at the drill hole near the center of sec. 17, T. 88 N., R. 3 E. (p. 74), where it is 51 feet thick. The hole in sec. 8, T. 88 N., R. 3 E., shows 48 feet of the brown shaly unit (p. 73). Drill holes in a belt about 3 miles wide, extending southwestward from these 2 holes to the southwest corner of the quadrangle, show from 40 to 4.5 feet of the brown shaly unit.

The upper part of the brown shaly unit is a zone of about 10 feet of yellowish-brown argillaceous crystalline dolomite and shale. These brown dolomite beds have been seen: in rock cuttings from the drill holes in the south half of the quadrangle. Outcrops of these beds have been seen only at a few places. Cuttings from drill holes in secs. 4 and 5, T. 88 N., R. 2 E., did not show the brown dolomite beds at the top of the brown shaly unit.

The lower 20 feet of the brown shaly unit forms rare outcrops in freshly slumped creek banks or in the steep headward part of gullies. 
The basal 2 to 4 feet of the Maquoketa shale contains very abundant depauperate fossils. This is the depauperate zone and has been seen in outcrops or rock cuttings from drill holes at many places in the quadrangle. A section including this zone was exposed in the fall of 1956 when excavations were made for the abutments of the highway underpass at Grandview Avenue in the NE1/4 SE1/4. sec. 36, T. 89 N., R. 2 E.

Section of Maquoketa shale exposed at Grandview Avenue in the $N E_{1 / 4}^{1 / 4 E^{1 / 4}}$ sec. 36 , Surficial: T. 89 N., R. $2 E$.

Loess

Feet

Till

Till

Upper Ordovician:

Maquoketa shale:

7. Siltstone and shale, grayish- to yellowish-brown, dolomitic; abundant comminuted fossils; vugs contain barite crystals_

6. Shale, dark grayish brown, thinly laminated............

5. Phosphate rock, gray to brown dolomitic, coarse-grained, crumbly; composed of phosphatic depauperate fossils and small phosphatic pellets.

4. Shale, soft, yellowish-green with greenish-blue streaks_....

3. Phosphate rock, conglomeratic, gray to brown, crumbly; composed of rounded phosphatic pellets as much as $1 \mathrm{~cm}$ in diameter in matrix of $1-\mathrm{mm}$ phosphatic discoidal "seeds"

2. Phosphate rock, indurated, gray, continuous but irregular; contains normal-sized cephalopods, brachiopods, and rarely trilobites

1. Limonite; commonly shows pseudomorphs after pyrite and marcasite

Middle Ordovician:

Galena dolomite:

Dolomite, irregularly bedded, yellowish-orange; pitted upper surface.

Beds 1, 2, 3, and 5 have been seen in nearly all outcrops of this zone, but beds 4,6 , and 7 are discontinuous. The limonite of bed 1 does not appear in unoxidized rock cuttings from drill holes, but the basal contact does have much iron sulfide which, when oxidized, is the limonite layer. Bed 5 of the section at Grandview Avenue has the most depauperate fossils; but depauperate fossils occur throughout the lower 20 feet of the brown shaly unit.

The thin basal phosphatic layer, bed 2 of the Grandview Avenue section, does not contain depauperate fossils; instead it has normal- 
size cephalopods, brachiopods, and rarely trilobites. The most common fossil in this layer is Beloitoceras, a stubby, tapered, and curved cephalopod about 2 inches long. Specimens of a trilobite resembling Flexicalymene sp. were found from this bed at an outcrop in the SE $1 / 4$ NE $1 / 4$ sec. 27, T. 89 N., R. 2 E. Rounded and angular pebbles of phosphatic material also are in this bed.

The ecologic conditions existing when most of the brown shaly unit was deposited were probably similar to those described by Pettijohn (1949, p. 457-459) for the deposition of black-shale facies.

The contact between the Maquoketa shale and the underlying Dubuque shaly member of the Galena dolomite, although regionally disconformable, is apparently conformable in the mining district because the Dubuque has a uniform thickness. However, the upper surface of the Dubuque shaly member is pitted, as seen at a highway excavation in the NW1/4.SE1/4 sec. 1, T. 88 N., R. 2 E. At this location several thousand square feet of the upper surface of the Dubuque was exposed in 1956, showing a ubiquitous surface having pits as deep as 5 inches. The limonite and (or) the phosphate layer, beds 1 and 2 of the Grandview Avenue section, are welded to the pitted dolomite surface. The pitted surface, abrupt change in lithology, abundant phosphatic nodules and pebbles, and iron sulfide are common features at unconformities; but the only positive statement that can be made about this contact is that it marks a definite change in sedimentation and possibly a disconformity.

BRAINARD MEMBER

The Brainard was named by Calvin (1906a, p. 60, 97) for outcrops near Brainard, Fayette County, Iowa, and is the middle unit of the Maquoketa shale in the Dubuque South quadrangle. The Brainard member has a maximum known thickness of 190 feet at the drill hole near the southeast corner of sec. 20, T. 88 N., R. 2 E. (p. 82), and a minimum known thickness of 79 feet at the drill hole in the NW1/4 sec. 1, T. 87 N., R. 2 E. (p. 86). The thickness is varied because the erosion which produced the disconformity at the top of the Maquoketa shale has removed much of the Brainard member.

The Brainard member in this quadrangle includes rock similar to that at the type section. It comprises mainly nonfossiliferous yellowish-green and greenish-gray soft dolomitic shale, which is sticky and plastic when wet. Holes drilled through this shale are squeezed shut within a few days unless cased.

The upper 60 feet of the Brainard at the drill hole in the SE1/4. sec. 20, T. 88 N., R. 2 E., has interlayered yellowish-green soft shale 
and light-gray coquinoid dolomite. The fauna consists mainly of brachiopods and bryozoans. These fossiliferous dolomite beds also were penetrated in the drill hole in the NW $1 / 4 \mathrm{SE} 1 / 4$ sec. 28 , T. $88 \mathrm{~N}$., R. 2 E. (p. 83). The beds rarely crop out because this zone is predominantly soft shale, but outcrops do occur in some of the steep gullies in secs. $20,21,22$, and the NW1/4 sec. 26, T. 88 N., R. 2 E. Ladd (1929, p. 331) called this fossiliferous zone the Cornulites zone after the fossil worm tube Cornulites sterlingensis, which in the Maquoketa shale is unique to these upper beds of the Brainard member.

\section{NEDA MEMBER}

The Neda formation, here considered a member of the Maquoketa shale, was named by Savage and Ross (1916, p. 187-193) for exposures near Neda in eastern Wisconsin. The Neda had previously been called the Mayville iron ore by Chamberlin (1877) and was correlated with the Clinton iron-bearing beds of New York. The Neda is as much as 55 feet thick in the vicinity of Mayville, Wis., where it was mined for iron.

Savage and Ross (1916) found marine fossils of Richmond age in the lower part of the Neda, thus discounting its correlation with the Clinton iron ore of Silurian age. Ulrich (1924) included the Neda in the Maquoketa group and recognized an unconformity between the Neda and the overlying rocks. The only exposure heretofore reported in Iowa (Howell, 1916) is on Lore Hill 3 miles northwest of the northwest corner of the Dubuque South quadrangle. Occurrences of the Neda in a broad band extending northeastward across Iowa have been reported from subsurface studies by Agnew (1955b, fig. 4) who noted that the Neda occurs only in areas where the thickness of the Maquoketa shale is nearly maximum. Workman (1950, p. 180) also noted this relation in northeastern Illinois.

Plate 2 shows the location of Neda occurrences in the Dubuque South quadrangle. The member also crops out in the parts of secs. 17,20 , and 29, T. 88 N., R. 2 E., west of the quadrangle area. The Neda was observed in rock cuttings from the drill hole near the southeast corner of sec. 20 and from the hole near the center of sec. 28 , T. 88 N., R. 2 E.

The Neda member comprises interlayered grayish-red soft shale, dolomitic dark-reddish-brown limonitic oölite, and grayish-green shale. The oolitic beds dominantly consist of jumbled limonite concretions which are flattened 1-mm spheroids having concentric shells. Thin sections show that the concretions commonly have, fragments of phosphatic nodules or grains of quartz silt for nuclei and the groundmass comprises fine dolomite grains, fragments of phosphatic 


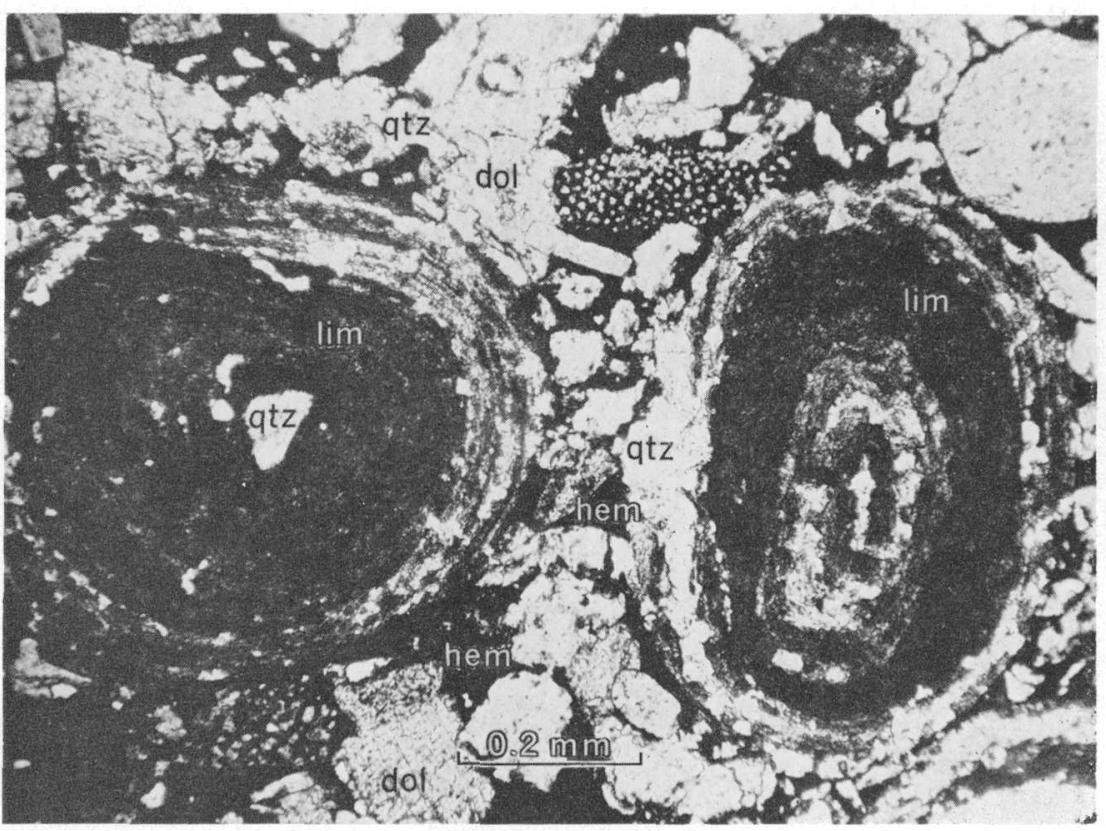

Figure 7.-Photomicrograph of Neda member of the Maquoketa shale from the SW1/4, sec. 21 , T. 88 N., R. 2 E., showing limonite oolite $(\mathrm{lim})$ with quartz nucleus in matrix of dolomite $(d o l)$ and quartz grains $(q t z)$ cemented with hematite (hem) and clay. Plain light.

nodules, clay, and quartz silt, all cemented by hematite. Many of the limonite concretions have shrinkage cracks that are filled with clay and calcite (fig. 7).

Irregularly shaped phosphatic nodules, probably collophane, averaging $1 \mathrm{~cm}$ but commonly $5 \mathrm{~cm}$ long are mixed with the limonite concretions. These nodules are yellowish brown, rounded, and have a hard glazed surface. The larger ones commonly have limonite concretions embedded in them, forming small pits if the concretions are removed by weathering or abrasion. Some of the smaller nodules have the shape of fossils, and some of the larger nodules seem to be an aggregate of smaller nodules.

The shale layers are grayish red and crumbly and have a few scattered lenses of limonite concretions. Dolomite rhombs and quartz silt are common in the shale. Where the Neda is thickest, a bed of grayish yellow-green to greenish-gray dolomitic soft shale is above the red shale layers. This shale also contains scattered limonite oölites intermixed with fine pyrite grains. Some of the oölites have been leached of iron oxide, leaving a small black residue of clay (fig. 8). Workman (1950, p. 181) reports a similar residue, which was identified as illite by R. E. Grim. 
The Neda member is thickest in the outcrops in the $\mathrm{NW}_{1 / 4} \mathrm{SW} 1 / 4$ sec. 21 and in the drill hole near the southeast corner of sec 20 , 'T. 88 N., R. 2 E. Near these places the Neda member is 3 to 5 feet thick; outcrops in sec. 20 show about 2 feet of the member. It wedges out completely in secs. 15, 22, and west of the mapped area, in 17 and 29, T. 88 N., R. 2 E.

Figure 9 shows the stratigraphic relation between the Neda member and adjacent rocks, and the following stratigraphic section is from an area in the quadrangle where the Neda is thickest.

Outcrop in ravine in the $N W 1 / 4 S W 1 / 4$ sec. $21, T .88 N ., R$. $2 E$.

Lower Silurian:

Kankakee formation:

Dolomite, pale-greenish-yellow, even-bedded, fine-grained; chert

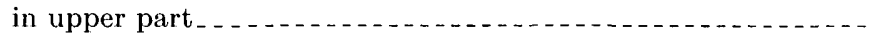

Feet

Edgewood dolomite:

$5+$

Tete des Morts member:

Dolomite, grayish-orange, medium-grained, porous, massive; fine fossil molds produce the porosity; two stylolitic seams near middle of bed

Mosalem member:

Dolomite, mottled light-olive gray and yellowish-gray, finegrained, many fine black phosphatic and pyritic specks; interbedded green silty shale; dolomite weathers to ocherous porous dolomite

Upper Ordovician:

Maquoketa shale:

Neda member:

Shale, greenish gray, soft, silty; many dark $1 \mathrm{~mm}$ limonite

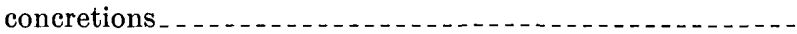

Oolite, limonite, dark reddish brown, hematite- and calcitecemented; grayish-red dolomitic crumbly shale and phos-

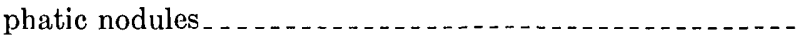

Shale, grayish-red, calcareous; mottled with grayish-green shale; scattered 1-mm limonite concretions

Oolite, limonite, dark reddish brown, hematite- and calcitecemented; composed of 1-mm limonite concretions, grayishred dolomitic shale lenses, more shale in upper part, phos-

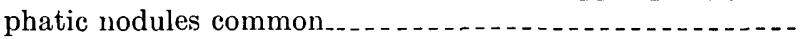

Brainard member:

Shale, pale yellowish green, dolomitic; interbedded with coarse crystalline, porous, phosphatic, coquinoid dolomite layers

The Neda member seems to be conformable with the Brainard member because beds of the Neda overlie beds of the Cornulites zone. Because the layers in the Cornulites zone are discontinuous, it is impossible to determine whether the Neda member consistently 


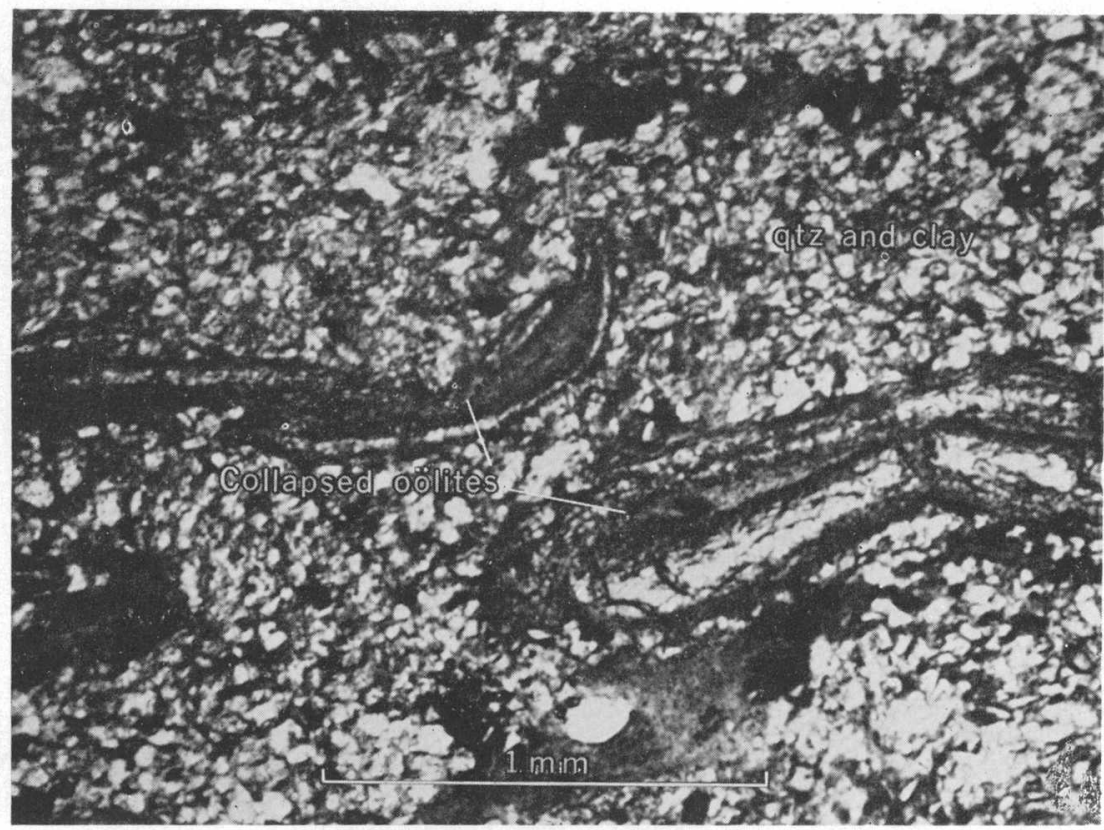

Figure 8.- Photomicrograph of Neda member of the Maquoketa shale from the same locality as figure 7 , showing leached and collapsed oolites having clay shell in matrix of quartz and clay. Plain light.

lies on the same bed. Therefore it is an open question whether the contact might be a slight disconformity.

Savage and Ross (1916) postulated that the Neda was deposited in intermittently connected shallow basins, the last vestiges of the Maquoketa sea. Agnew and others (1956, p. 301) suggest that the Neda represents a soil zone. The occurrence in the Dubuque South quadrangle seems to be a product of marine sedimentation in an oxidizing environment because the deposit is stratified, has few fossils, and is rich in ferric iron. The oolites would indicate turbulent conditions such as wave action in a shallow basin. The landmass providing the sediments was probably at low relief in a laterite-producing climate.

\section{SILURIAN SYSTEM}

Rocks of Silurian age form the cuesta in the southern third of the Dubuque South quadrangle. These rocks are separable into three formations which are, in ascending order, the Edgewood dolomite, the Kankakee formation, and the Hopkinton dolomite (pl. 3). They comprise as much as 300 feet of argillaceous dolomite, very cherty dolomite, and pure coralline dolomite respectively. Be- 


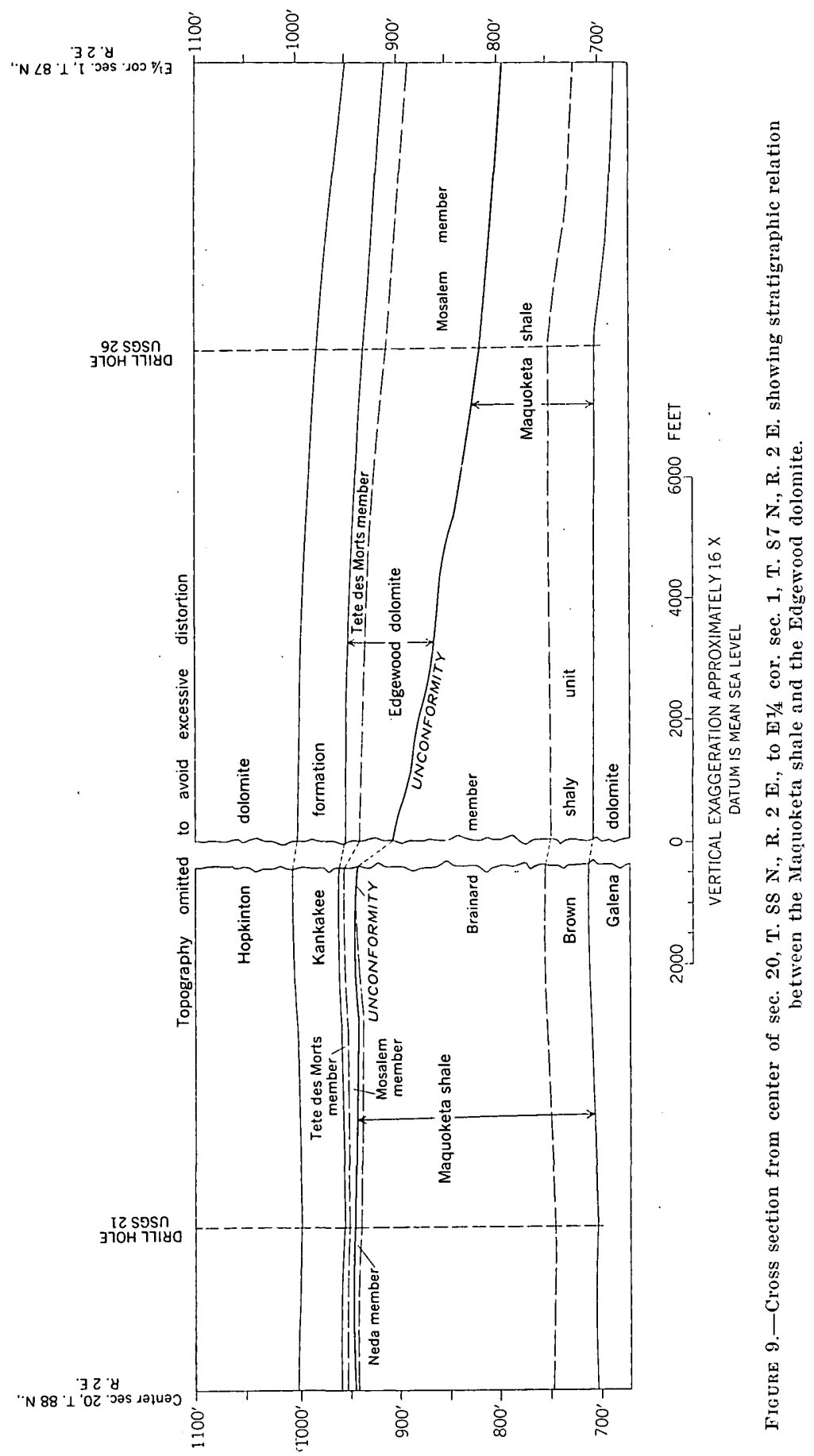


fore deposition of these rocks the area was uplifted and,eroded; as a result, the Silurian strata lie unconformably on the Maquoketa shale.

Calvin and Bain (1900) studied the rocks of Silurian age in Dubuque County. They divided the rocks into seven units (1900, p. 459), which we correlate as follows:

- Calvin and Bain ('Thickness, in feet)

7. Upper quarry beds......... 20

6. Cerioniles beds........ 25

5. Pentamerus beds......... 50

4. Syringopora beds___._._. 65

3. Chert beds ............ 25

2. Lower quarry beds........ 20$\}$

1. Basal beds. ..................

Total thickness
15 Tete des Morts member of the IDdgewood dolomite

Most of the outcrops studied by Calvin and Bain were in western Dubuque County in an area of generally thick Maquoketa shale. There basal shaly beds of the Edgewood dolomite lie on the dolomitic shale and dolomite of the Maquoketa shale. Consequently, Calvin called the lower shaly Edgewood the "transition beds" (1898, p. 142) and included them in the Maquoketa shale. This erroneous interpretation was unavoidable because the nature of the OrdovicianSilurian unconformity was unknown.

The following section shows the similarity of the lower shaly Edgewood and the Cornulites zone of the Maquoketa shale.

Outcrop in ravine near the Dubuque Municipal Airport in the $S W 1 / 4 N W 1 / 4$ sec. 26,

Middle Silurian: T. 88 N., R. $2 E$.

Hopkinton dolomite:

Dolomite, grayish-yellow, massive-bedded, porous, noncherty _. - 10

\section{Lower Silurian:}

Kankakee formation:

Dolomite, pale-grayish-yellow, dense; as much as 40 percent

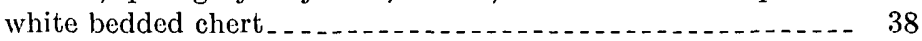

Dolomite, grayish-yellow, dense, even-bedded; 5 percent white nodular chert.

Edgewood dolomite:

Tete des Morts member:

Dolomite, grayish-orange, thick-bedded, porous. . . ........

Mosalem member:

Dolomite, grayish-orange, argillaceous, wavy-bedded; 1 foot

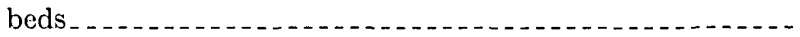

Dolomite, olive-gray, argillaceous, wavy-bedded, dense; 0.2 to 0.5-foot beds; thinly laminated pyritiferous dolomite bed in lower 1 foot; green shale partings... 
Unconformity (surface is limonite stained and has 1 foot of relief in area of outcrop).

Upper Ordovician:

Maquoketa shale:

Brainard member:

Dolomite, light-olive-gray, fossiliferous, medium-grained, porous, wavy-bedded; as much as 50 percent intercalated grayish-green shale layers

Shale, grayish-green, soft

Shale, as above; nodular lenses of gray, fossiliferous, mediumgrained dolomite

The contact shown in this outcrop appears transitional because Maquoketa shale was reworked and mixed with the overlying sediments of Early Silurian age; nevertheless, the thin limonite-stained layer marks the contact. Also, the dolomite above the contact has few fossils, and the beds below are very fossilferous.

Scobey (1938) described the Edgewood dolomite and Kankakee formation in northeastern Iowa. We agree with most of his conclusions. He also includes faunal lists for these formations (1938, p. 212-213).

\section{LOWER SILURIAN SERIES}

\section{EDGEWOOD DOLOMITE}

The Edgewood dolomite was named by Savage (1909, p. 517-518) for exposures 3 miles north of Edgewood, Pike County, Mo. Rocks that occupy a similar stratigraphic position in northwestern Illinois and northeastern Iowa were named the "Winston dolomite" (Savage 1914, p. 34-37). In 1926 Savage (1926, p. 526) correlated the Edgewood with the Winston dolomite and discarded the name "Winston." Sutton $(1935$, p. 275$)$ agrees with this correlation and abandonment.

Most information on the Edgewood dolomite in the Dubuque South quadrangle was obtained from the drilling done in 1955 for the U.S. Geological Survey (see p. 68). The Edgewood dolomite fills irregularities in the eroded surface of the Maquoketa shale, and its thickness is known to range at least from 9 to 116 feet in this quadrangle. A comparison of the isopach maps for the Maquoketa shale and the Edgewood dolomite (figs. 6 and 10) shows that the thicknesses of these two formations are nearly complementary.

The thinnest measured section of Edgewood is in the NW1/4 SW1/4 sec. 21, T. 88 N., R. 2 E. (see p. 30 ). Here the Edgewood is 9.8 feet thick and rests on the thickest measured section of the Neda member. This outcrop marks the approximate summit of a preSilurian Maquoketa shale hill. The Neda member is beveled off on the slopes of this hill; conversely the Edgewood dolomite thickens. Figure 9 shows this relation. 


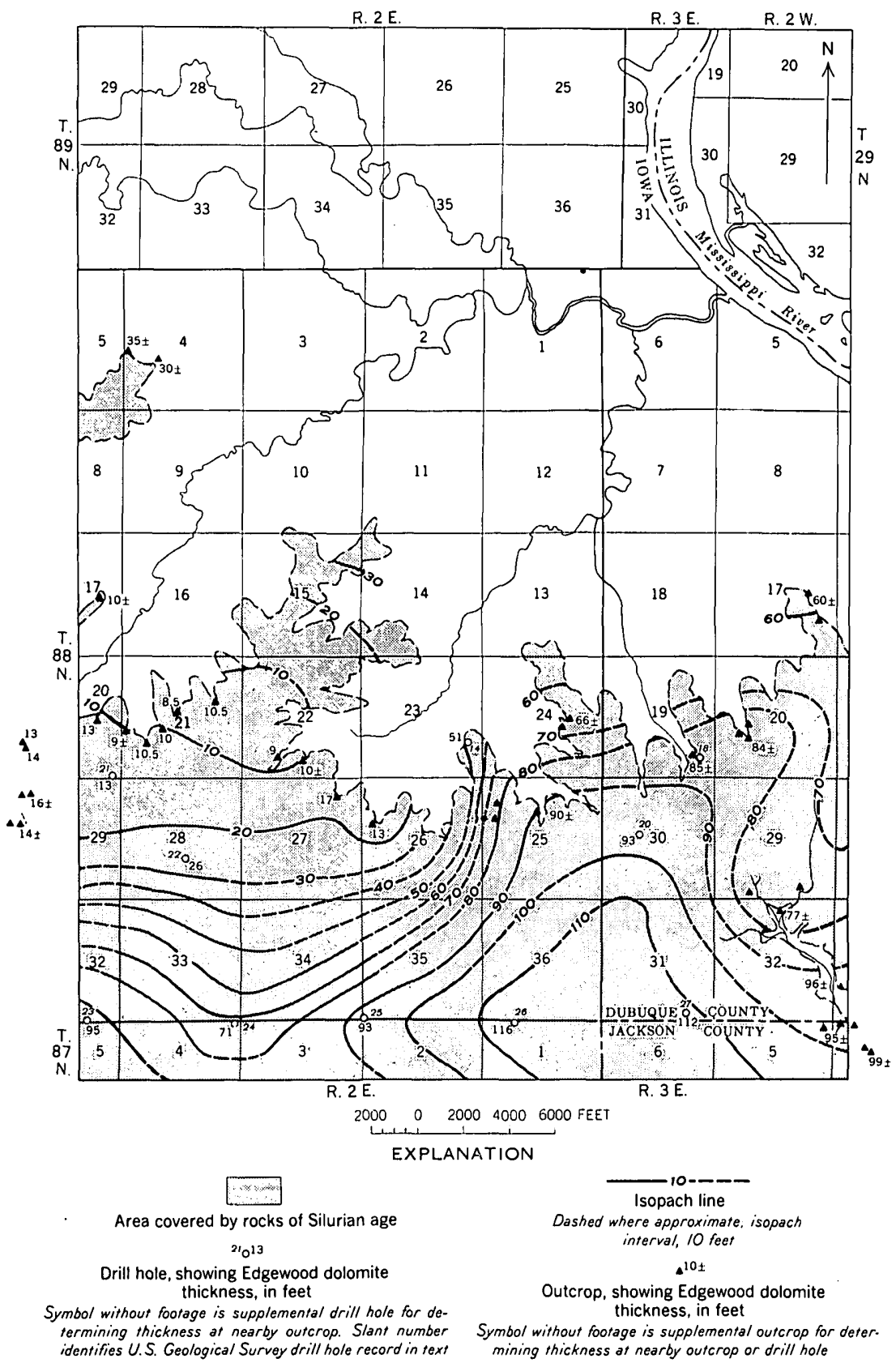

Figure 1.0.-Map showing thickness of Edgewood dolomite in the Dubuque South quadrangle. 
Although the thiclnesses of the Maquoketa shale and Edgewood dolomite are generally complementary, the combined thickness of the two formations is 20 feet greater in the area of thin Edgewood overlying the Maquoketa shale hill, than in areas of thin Maquoketa. This suggests that Edgewood dolomite drapes over the Maquoketa shale hill. However, we believe that much of the 20 -foot difference is due to compaction of the shaly fraction of the lower part of the Edgewood dolomite where the Edgewood is thick. Where the Edgewood is thin, content of argillaceous material is insignificant, and the differences in thickness resulting from its compaction are negligible.

We believe that the Edgewood dolomite is a shallow-water marine deposit formed in a sea that transgressed over the eroded surface of the Maquoketa shale. While sediments were being deposited in the low places, Maquoketa shale hills such as the one in this quadrangle were either above sea level or, if covered by the sea, were not receiving sediments. Fragments of the upper part of the Maquoketa shale in local conglomerate layers of the Edgewood dolomite indicate that these hills were being eroded as the Edgewood was being deposited. Much argillaceous material in the lower part of the Edgewood probably was eroded from the hills or islands of Maquoketa shale, and relative purity of the dolomite in the upper member of the formation is a result of the water's clearing after the summits of the Maquoketa shale hills were covered by sediments.

The Edgewood dolomite is separable into two lithologic units. We propose to name these units, in ascending order, the Mosalem and Tete des Morts nembers.

\section{MOSALEM MEMBER}

The Mosalem member is named for exposures along the Niagaran escarpment in Mosalem township, Dubuque County, Iowa. The lithology and thickness of the member has many local variations, therefore a specific exposure can not be called typical of the Mosalem member. Outcrops that show many of the lithologic features characteristic of the Mosalem are: (a) north of the eastward-flowing stream in the SE $1 / 4 . \mathrm{SE} 1 / 4$ of sec. 32 , T. 88 N., R. 3 E.; (b), east of the southward-flowing stream in the NW1/4NE1/4, of sec. $32, \mathrm{~T} .88$ N., R. 3 E.; (c) a road cut along U.S. Highway 67 east of the Dubuque South quadrangle in the SE $1 / 4$ of sec. 27 , T. 88 N., R. 3 E.; and (d), one-half mile south of Bellevue, Jackson County, Iowa along U.S. Highway 67.

The Mosalem member differs lithologically in areas of thin Edgewood from areas of thick Edgewood. This lithologic change is 
transitional, but for ease of description it is arbitrarily set where the formation is 40 feet thick.

The member where the Edgewood is thick comprises 30 to 94 feet of wavy-bedded argillaceous pale-grayish-orange to olive-gray dolomite and has chert nodules and pale-brown to olive-gray shale partings (fig. 11). These rocks become more argillaceous, have more shale and are darker toward the base. The basal 5 feet of rock is mottled with markings resembling filled worm holes. Abundant black phosphatic elongate specks are disseminated in the lower 40 feet where the Edgewood is thickest. The specks are particularly abundant in the basal 5 feet. A study of thin sections indicates that these minute specks are probably conodonts composed of collophane. Angular quartz silt is also common in the lower few feet and locally equals 10 percent of the rock. Glauconite and pyrite are common near the base, and traces of barite and sphalerite have been seen but apparently are rare.

Fossils in the Mosalem member of the Edgewood are dominantly brachiopods, bryozoans, and trilobites but are poorly preserved specimens. Small phosphatic fossils similar in appearance to the depauperate fauna of the basal Maquoketa shale were observed in the lowest bed of the Edgewood at the center of the E1/2 sec. 17, T. 88 N., R. 3 E.

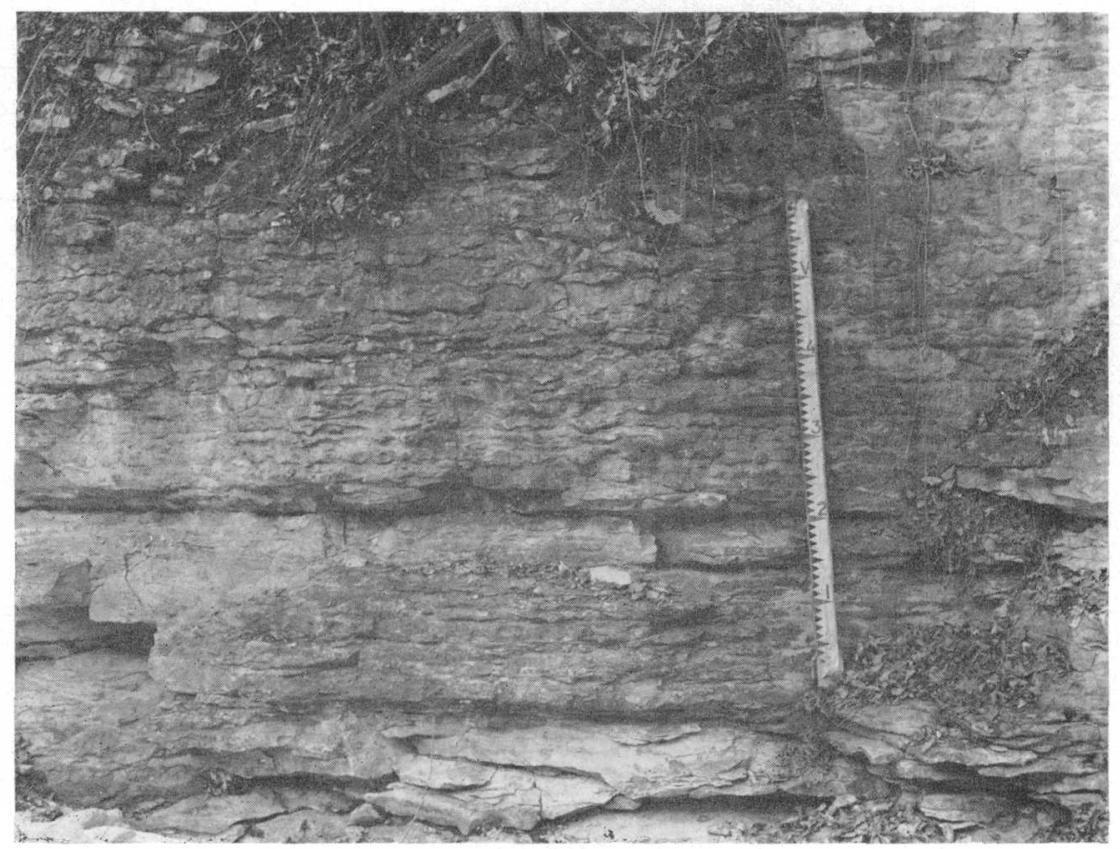

Figure 11.-Outcrop of Edgewood dolomite in the SE1/4 SE1/4 sec. 32 , T. 88 N., R. 3 E., showing wavy-bedded shaly dolomite of the Mosalem member. 


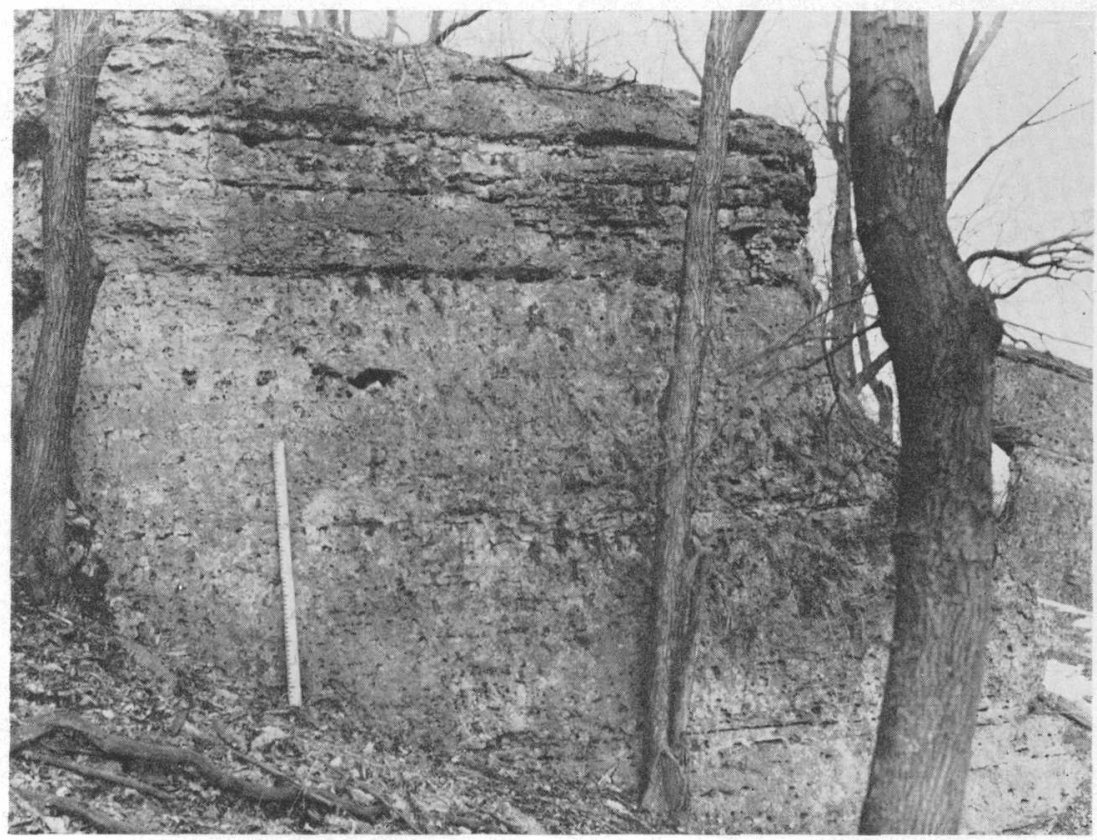

Frgure 12.- Outerop of Edgewood dolomite in the same locality as figure 11, showing massive-bedded dolomite of the Tete des Morts member.

Earthy pale-yellowish-brown chert nodules having white powdery rinds are common mainly in the Mosalem member. These nodules are rarely coalesced into bands. Commonly the chert is not more than 5 percent of the rock and does not exist where the Edgewood is thin. Chert oceurs in euttings of the Edgewood at the drill hole in the SE $1 / 4$ sec. 23 , T. 88 N., R. 2 E., where the total thickness of the formation is 51 feet $(\mathrm{p} .77)$. This is the thinnest section of Edgewood known to contain chert in this quadrangle.

The basal few inches of rock in the areas of thin Edgewood dolomite are locally a grayish-yellow colloform-laminated dolomite. The fine laminae are bands of fine anhedral intermeshed dolomite grains alternating with dolomite grains mixed with quartz silt. The colloform layering could be irregular ripple marks, but an organic origin, possibly algal, is also suspected.

Phosphatic nodules, glauconite, and fine quartz grains are common in the lower part of the member where it is thin. Pyrite is very abundant, particularly as microscopic grains, and makes the basal layers very tough, dense, and dark bluish gray, if unoxidized. Where weathered, these rocks are porous and heavily limonite stained.

Locally a dolomitic basal conglomerate, commonly less than 0.5 foot thick, occurs near the eroded fringe of the Neda member of 


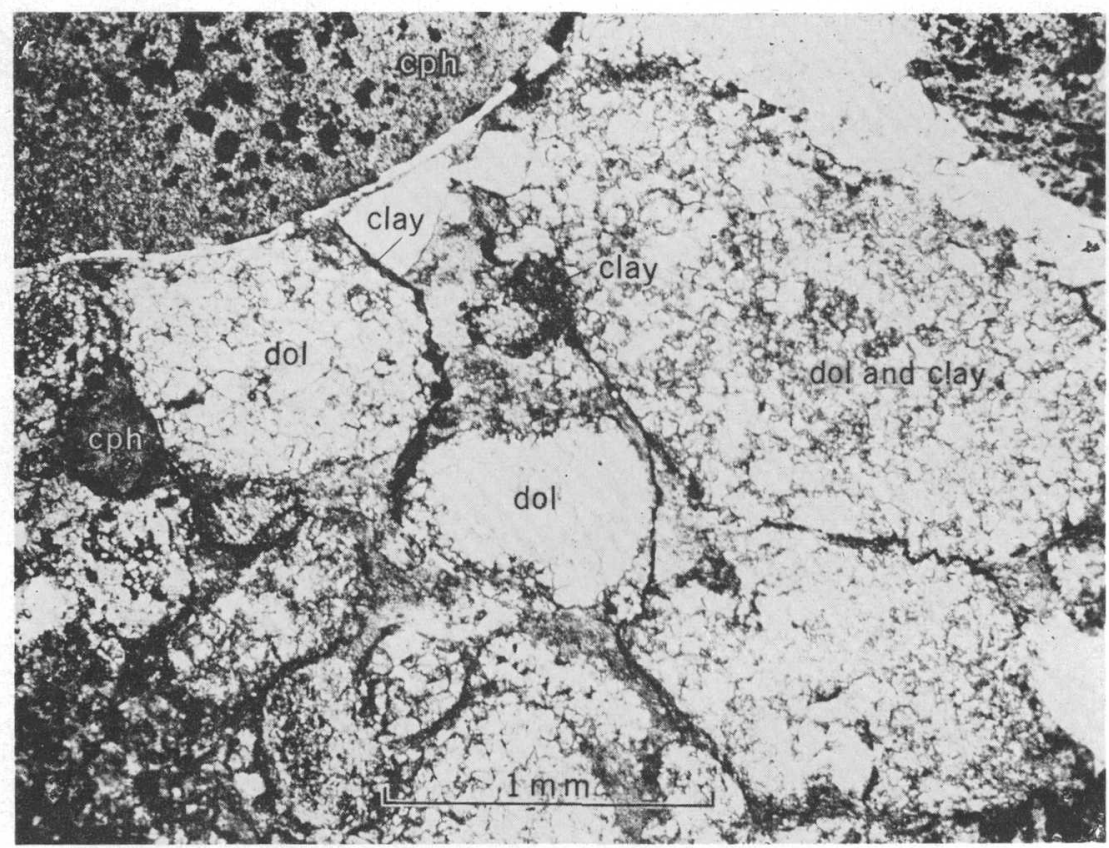

FIGURE 13.-Photomicrograph showing detrital dolomite and phosphatic nodules from basal Edgewood dolomite from SW1/4, sec. 17, T. 88 N., R. 2 E. Plain light; (dol) dolomite, (cph) phosphatic nodule "collophane."

the Maquoketa shale. It contains abundant pitted phosphatic nodules, fragments of oölite from the Neda, and green shale and comminuted fossil fragments from the Cornulites zone of the Brainard member of the Maquoketa. Angular pebbles of dolomite from the Cornulites zone also are included; but because the conglomerate has a dolomitic matrix, these fragments are not obvious in a megascopic examination (fig. 13). Although the basal conglomerate was mainly seen close to the eroded fringe of the Neda member, it also occurs in an outcrop one-half mile east of the quadrangle area, near the center of sec. 21 , T. 88 N., R. 3 E. Possibly a buried Maquoketa shale hill is also in this vicinity.

TETE DES MORTS MEMBER

The Tete des Morts member of the Edgewood is named for the many cliffs formed by these rocks (fig. 12) along the headwater drainage of the Tete des Morts River in Jackson and Dubuque Counties, Iowa.

The Tete des Morts member which forms many bluffs, contrasts sharply with the underlying shaly beds of the Mosalem member, which rarely crops out. Large slump blocks from these bluffs are 
common on the slope below the Niagaran escarpment and along the Tete des Morts River.

The member correlates with beds 5, 6, and 7 shown by Willman and Reynolds (1947, p. 7) for northwestern Illinois. In southwestern Wisconsin it occurs on the Platte mounds as prominent ledges and large slumped blocks.

The Tete des Morts member is massive-bedded, medium-grained, finely porous, grayish-orange to grayish-yellow glauconitic dolomite having fine white siliceous specks. Glauconite is common but not abundant. Where the member is thick, nodular bands of chert occur in a 3-foot zone in the middle, commonly forming a reentrant. The fossils in the member are predominantly silicified Favosites sp. and concentrically banded fossils which are possibly stromatoporoids. The member is commonly 20 to 22 feet thick but is thinner over areas of thick Maquoketa shale.

The member is represented in the areas of thin Edgewood dolomite by a massive, porous, medium-grained, grayish-orange dolomite bed. This bed is less than 5 feet thick in sec. 21, T. $88 \mathrm{~N}$., R. 2 E., where the Edgewood is thiniest (see p. 30). It thickens outward from this area, as does the underlying argillaceous dolomite of the Edgewood as a whole. Although where it is thin the Tete des Morts member is noncherty fossils in it are silicified.

Two stylolitic seams about 1 foot apart occur in the middle of the member in the outcrops in sec. 21 and at a quarry in sec. 4, T. $88 \mathrm{~N}$., R. 2 E.

\section{KANKAKEE FORMATION}

The Kankakee formation was named by Savage (1916) for exposures along the Kankakee River 5 miles south of Richey, Ill., where it unconformably overlies the Edgewood dolomite. The lower contact is described in relation to a zone of Platymerella manniensis, which Savage included in the Edgewood but later workers included in the Kankakee. The upper contact also is described on a faunal basis.

E. H. Scobey (1938) studied the rocks of Silurian age in northeastern Iowa. He was unable to locate the faunal zones except at Sabula, Iowa; therefore he described the contacts mainly on a lithologic basis. We also used these marked lithologic changes as the upper and lower contacts of the Kankakee formation (figs. 14 and 15). The criteria are usable not only in mapping outcrops but also in subsurface studies. Scobey could find no evidence of an unconformity at either contact in northeastern Iowa. We also agree with this observation.

The Kankakee formation ranges in thickness from 50 feet where it overlies thick Edgewood dolomite in the southeastern part of the 


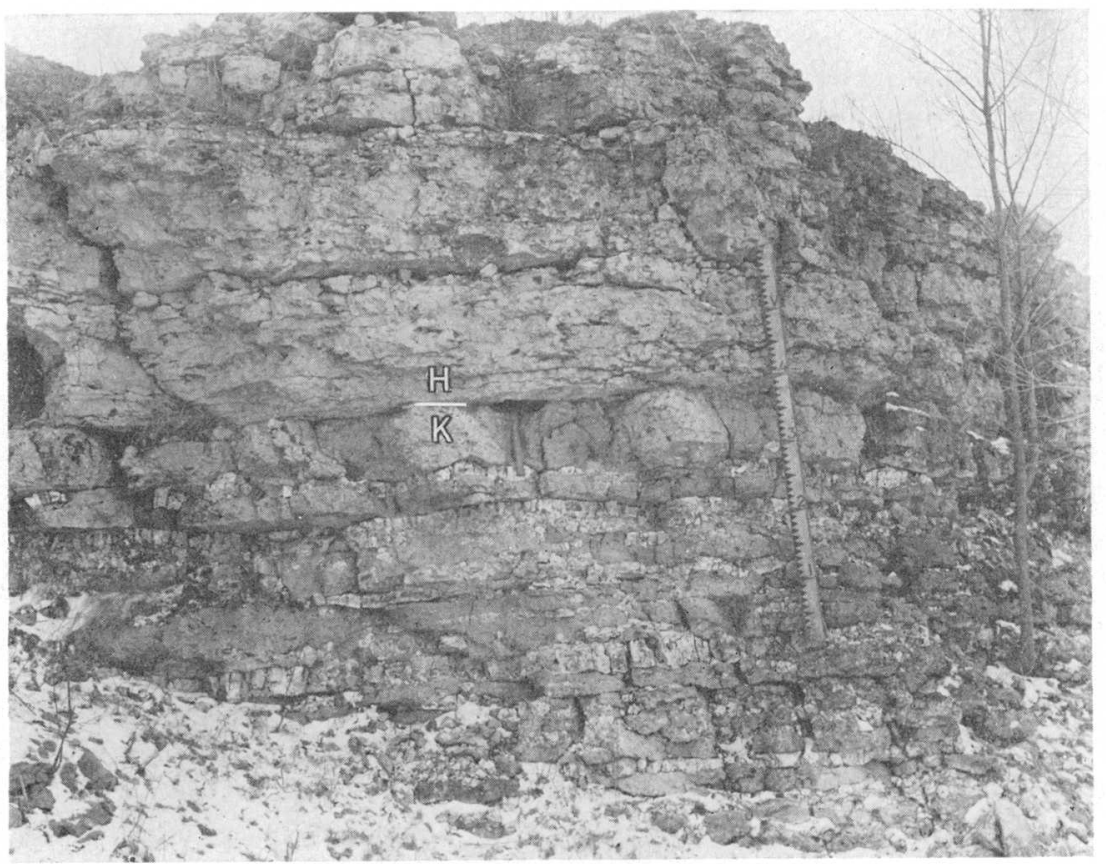

Figure 14.-Contact of Hopkinton dolomite and Kankakee formation, NW1/4 NE1/4 sec. 34, T. 88 N., R. 2 E.

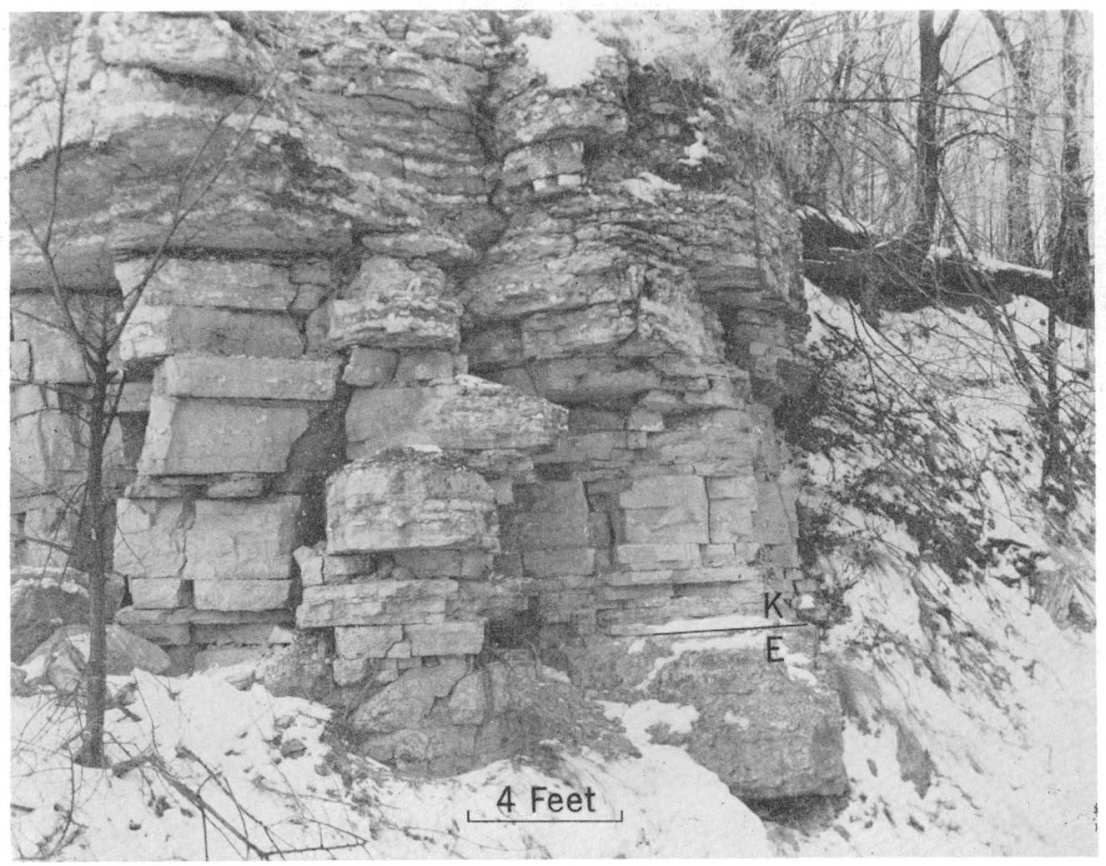

Figure 15. - Contact of Kankakee formation and Edgewood dolomite, SE1/4 SE $1 / 4$ sec. 17, T. 88 N., R. 3 E. 
quadrangle to 45 feet where it overlies thin Edgewood northwest of the Dubuque Airport. This change of thickness is due to draping by the Kankakee sediments above the Maquoketa shale hill, which is reflected upward through the Edgewood dolomite by draping and differential compaction of the Edgewood sediments.

The Kankakee contrasts with the underlying Edgewood and overlying Hopkinton dolomite because it is lithologically uniform throughout the Dubuque South quadrangle. The Kankakee comprises grayish-yellow dense fine-grained dolomite and as much as 50 percent bedded chert in the upper 40 feet. The chert is porcelaneous, white and bluish-white, and has rare chalcedony and drusy quartz-lined vugs. The lower 8 feet of the formation is yellowishgray dolomite having scattered chert nodules (fig. 15). It is even bedded in beds 3 to 8 inches thick separated by thin green shale partings. These lower even beds are the "lower quarry beds" of Calvin and Bain, and their "chert beds" (p. 33) are the upper cherty part of the Kankakee formation. The lower quarry beds are thick northwest of the Dubuque South quadrangle and have been extensively quarried for dimension stone near Farley, Iowa.

The basal contact of the Kankakee formation is at an abrupt lithologic change, from the massive vuggy grayish-orange upper member of the Edgewood dolomite to thin even-bedded yellowishgray dolomite of the lower beds of the Kankakee formation (fig. 15). The top of the Kankakee is a conspicuous shale layer about 2 inches thick, which is from 1 to 2 feet above the highest chert of the Kankakee formation (fig. 14). A chert bed as much as 8 inches thick is commonly in the upper 2 feet of the cherty Kankakee. This chert layer helps identify the top of the Kankakee formation in outcrops.

The Kankakee formation has few extensive outcrops in the Dubuque South quadrangle. The formation was studied mainly in quarries, road cuts, and rock cuttings from drill holes. Its position on the escarpment and on the slopes of the Tete des Morts River valley is well marked by a flood of white chert fragments above the break in slope or cliff formed by the Tete des Morts member of the Edgewood dolomite. The entire Kankakee formation is exposed along U.S. Highway 151 in the SE1/4 sec. 17, T. $88 \mathrm{~N}$. R. 3 E.

The fauna of the Kankakee, although sparse, is made up dominantly of silicified corals, mainly Favosites favosus. Scobey (1938, p. 215) found a zone of Atrypa reticularis 6 feet below the top of the Kankakee formation to the southeast, but we were unable to locate this zone in the Dubuque South quadrangle.

A tough ferruginous residual clay having abundant chert fragments is produced on Kankakee bedrock. 


\section{MIDDLE SILURTAN SERIES}

HOPKINTON DOLOMITE

The Hopkinton dolomite was named by Calvin (1906b, p. 572, 574) for outcrops near Hopkinton, Delaware County, Iowa. $\mathrm{He}$ described the formation as 220 feet of locally very fossiliferous dolomite between the rocks of Early Silurian age and the top of the Pentamerus-bearing beds.

In the Dubuque South quadrangle the Hopkinton covers most of the dip slope of the cuesta and extends northward to the brow of the escarpment. Except for the lower 15 feet, which is a cliff former, outcrops of the Hopkinton are sparse in this quadrangle. Most of the information about the Hopkinton dolomite in the Dubuque South quadrangle is from studies of drill-hole data. The formation has been examined in several quarries and outcrops southwest of the quadrangle area in order to have a better understanding of the rocks studied from drill holes in this quadrangle.

We included all rocks overlying the Kankakee formation in the Hopkinton dolomite, because the Gower dolomite of Norton (1899), which overlies the Hopkinton in eastern Iowa, has not been recognized in the Dubuque South quadrangle. Possibly some rocks mapped by us as Hopkinton dolomite are correlative with the Gower dolomite.

The rocks overlying the Kankakee formation at the drill hole near the southeast comer of sec. 20 , T. 88 N., R. 2 E. (p. 82 ), are 135 feet thick; in a well near the northeast corner of sec. 36, T. $88 \mathrm{~N}$., R. 2 E., these rocks are as much as 195 feet thick, the maximum thickness known in the quadrangle.

The Hopkinton dolomite consists of pale-grayish-orange vuggy dolomite that is very fossiliferous and locally cherty. The lower 15 feet of rock is massive-bedded gnarly dolomite and has irregular green shale partings (fig. 14). This unit is uniformly noncherty and is the cliff former that makes the brow of the cuesta escarpment. Good exposures of this bed are also in the quarries in secs. 15 and 34, 'T. 88 N., R. 2 E. (fig. 14). Overlying this basal massive bed is 40 to 65 feet of grayish-orange cherty dolomite that locally has abundant specimens of Pentamerus oblongus. The chert is fossiliferous and white to bluish white, commonly with a powdery white rind.

Locally, as in the southeastern part of the quadrangle, chert comprises more than 50 percent of the rock. Zones heavily impregnated with chert have been seen in outcrop only in the center of the W1 $1 / 2$ sec. 30 , T. 88 N., R. 3 E., and in a road cut in the SW1/4 sec. 21, T. 88 N., R. 3 E., just east of the mapped area. These cherty zones are easily confused with the Kankakee formation in studies 
of rock cuttings from drill holes. Weathering of cherty Hopkinton dolomite produces vuggy blocks of limonite-stained chert as much as 3 feet in maximum dimension. The vugs in these blocks are lined with chalcedony and drusy quartz crystals. The chert blocks commonly have well-preserved fossils, predominantly Pentamerus sp. In the southwestern part of the quadrangle there is much less chert than in the southeastern part; however, this change is local rather than regional, because a quarry along the north edge of sec. 1, T. 87 N., R. 1 E., about 2 miles west of the southwestern part of the Dubuque South quadrangle, has abundant chert in the Pentamerusbearing zone. A tough ferruginous residual clay having abundant chert fragments is produced where the cherty zone is bedrock.

The rock above the cherty zone is relatively noncherty and is porous grayish-yellow coralline dolomite. Some of these beds, 32 feet of coralline porous pale-yellowish-gray dolomite having one chert band, are exposed at the quarry in the $\mathrm{SW} 1 / 4$ sec. 30, T. $88 \mathrm{~N}$., R. 3 E. Fossils from this quarry were identified by W. A. Oliver, Jr. of the U.S. Geological Survey. They are as follows:

\section{Fuvosites? cf. F. brownsportensis (Amsden) \\ Halysites (Halysites) 2 spp. \\ Propora aff. P. americana (Rominger) \\ Arachnophyllum cf. A. mamillare (Owen) \\ Cystiphyllum sp.}

The fossils in the Hopkinton are commonly silicified and weather out as float fragments. One large colony of silicified Catenipora cf. C. huronensis (Teichert), 1 foot in maximum dimension was found in sec. 20 , T. 88 N., R. 2 E. (fig. 16).

\section{QUATERNARY SYSTEM}

\section{PLEISTOCENE SERIES}

GLACIAL DRIFT

Most of the Dubuque South quadrangle west of the Mississippi River was originally included in the Driftless Area by T. C. Chamberlin (1883, p. 269). Later, however, he recognized till here and included this area in the attenuated pebble drift zone (Chamberlin and Salisbury, 1885, p. 275).

Williams ${ }^{1}$ studied till in eastern Dubuque County. He concluded that the till is of Nebraskan age because it remains only on the divides, thus indicating that the present valleys were cut after the Nebraskan till was deposited. Trowbridge (1954, p. 803) agrees with this conclusion. Kansan till in western Dubuque County and west of this area covers both hills and valleys.

\footnotetext{
1 Williams, A. J., 1923, Physiographic history of the "Driftless Area" of Iowa: unpublished Ph.D. thesis, Iowa University, Iowa City, 116 p.
} 


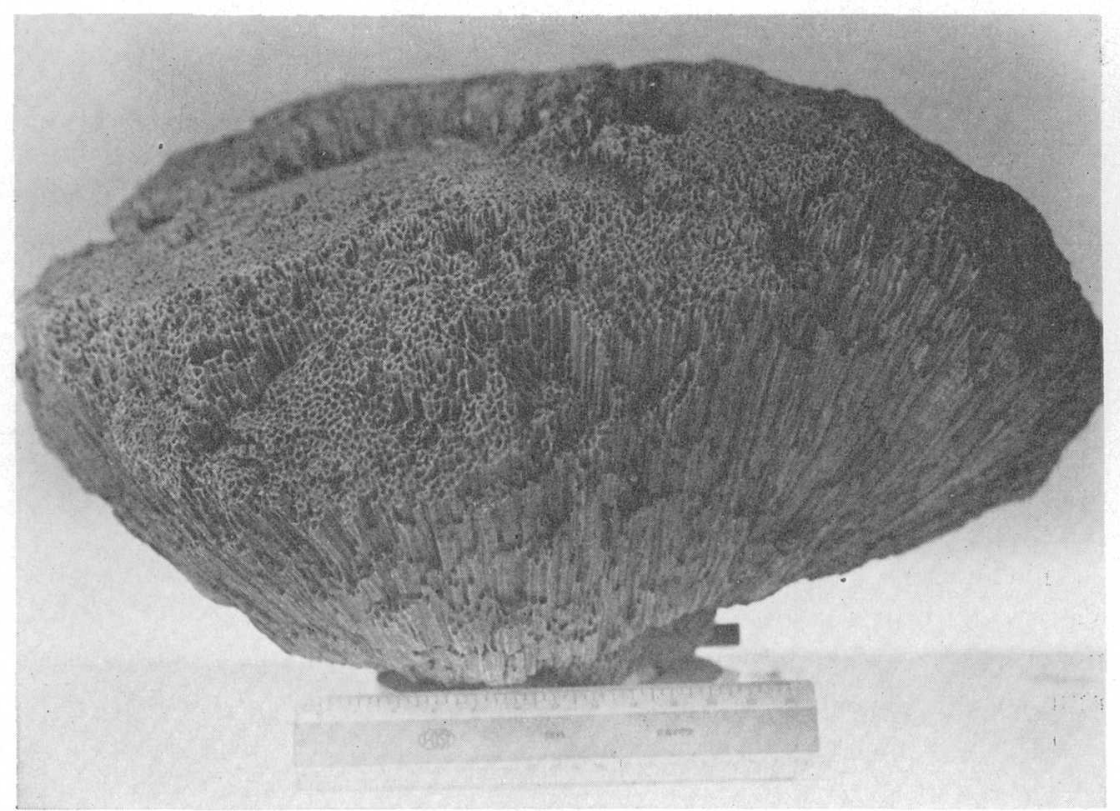

FIgURE 16.-Silicified Catenipora ef. C. huronensis from the Hopkinton dolomite, SW $1 / 4 \mathrm{SE}^{1 / 4}$ sec. 20 , T. 88 N., R. 2 E.

Till occurs on most of the uplands in the Dubuque South quadrangle. It has few natural exposures but is represented in gullies and steep hillsides mainly by faceted and striated glacial erratics, which have eroded out of the till where headward erosion has transgressed its border. The till was exposed in excavations for the underpass beneath Grandview Avenue near the center of the E1/2 sec. 36, T. 89 N., R. 2 E., where it is 8 feet thick, and in a ditch dug for a water main on Pennsylvania Avenue at the middle of the north edge of sec. 27 , T. 89 N., R. 2 E., where the till was at least 14 feet thick. A natural outcrop of till up to 20 feet thick is near the center of the $\mathrm{SE} 1 / 4$ sec. 32 , T. 89 N., R. 2 E., in a gully. Glacial drift has also been seen in the surficial material from some of the holes drilled for the U.S. Geological Survey in 1955. The location of till exposures and erratics, and of drill holes that penetrate till is shown on plate 2 . 'Till is not shown on the geologic map because of spotty occurrences and indefinite boundaries.

The till is generally bouldery clay with many chert and quartz pebbles. The clay is yellowish brown and granular and has a waxy appearance; the lower part is commonly grayish. The glacial deposits in the southwestern part of the quadrangle and in secs. 12, 13 , and 18, T. 88 N., R. 2 E., are composed of ferruginous gravelly sand containing many cobbles. This material represents many varieties of igneous and metamorphic rocks. 
The ridge in the south half of sec. 33, T. 89 N., R. 2 E., has an exceptional thickness of till. The drill hole near the center of the $\mathrm{S} 1 / 2$ sec. 33 (p. 70 ), penetrated 58 feet of surficial material of which 17 feet is soil and loess and the rest is till. Records of holes one-fourth mile east of this one show as much as 40 feet of surficial material and till. The erratics in this part of sec. 33 and also in sec. 32 are generally larger than those seen elsewhere in the quadrangle. Some granite boulders are as much as 3 feet in diameter.

The part of the quadrangle south of the escarpment of Silurian rocks has less till than that north of the escarpment. Some of the drill holes show as much as 12 feet of till, but we saw few outcrops of till.

: In the part of the Dubuque South quadrangle in Illinois no till was seen, but a well in the $\mathrm{N} 1 / 2 \mathrm{SE} 1 / 4$ sec. 20 , T. $29 \mathrm{~N}$., R. $2 \mathrm{~W}$., penetrated 40 feet of surficial material, including 15 feet of sand and coarse fragments of rock foreign to this area, probably till.

\section{ALIUVIUM}

The terraces along the Mississippi River are discussed on page 8. The gravel, sand, and silt of these deposits is of late Wisconsin age according to Trowbridge (1954, p. 803).

Most of the streams originating in the area of Silurian rocks have channel deposits of chert gravel on the valley floors. A similar deposit of chert is near the east edge of sec. 1, T. $88 \mathrm{~N}$, R. 2 E., east-southeast of Rockdale. This deposit, which is now more than 100 feet above nearby streams, is a channel on an old erosion surface (p. 7).

\section{LOESS}

Loess of irregular thickness overlies the bedrock and till at many places in the Dubuque South quadrangle. It is as much as 30 feet thick and is commonly thicker east of the Mississippi River, probably because the prevailing westerly wind carried silt from the flood plain and deposited it east of the river. Loess is not shown on the geologic map because of its spotty occurrences and indefinite boundaries.

\section{STRUCTURE}

The Upper Mississippi zinc-lead district is in an area of comparatively minor structures surrounded by the following major structural features of the Central States: The Wisconsin dome in central Wisconsin to the north, the north- to northwestward-trending Wisconsin arch to the east, the Illinois basin to the south, and the Forest City basin to the west and northwest. 
The Paleozoic strata have a regional dip in the mining district of about 18 feet per mile to the south-southwest away from the Wisconsin dome and the Wisconsin arch. The regional dip is interrupted by east- to east-northeastward-trending anticlines and synclines as much as 50 miles long and having 200 feet of structural relief. Fold axes in the northwestern part of the district turn northwestward (Heyl and others, 1955, pl. 25).

Folding in the mining district was studied by A. V. Heyl, Jr., and others $(1959$, p. $27-35)$. They believe that the east- to northeastward-trending folds were produced by northward-directed compression from the Illinois basin and the northwestward-trending folds by a lesser northeastward compression or simply a holding force from the Forest City basin. They indicate first-order folds as those greater than 20 miles long and having 100 to 200 feet of structural relief; second-order folds as those from 2 to 20 miles long and having 50 to 100 feet of structural relief; and third-order folds as less than 2 miles long and having less than 50 feet of structural relief. This classification will be used in this report.

The Dubuque South quadrangle is located between two first-order folds. A southwestward-trending syncline having its axis near Galena, Illinois, extends into Iowa near the mouth of the Tete des Morts River 7 miles east of the southeast corner of the quadrangle area. Its further extent in Iowa is unknown. A westward-trending fold, called the Meekers Grove anticline, has been traced for at least 25 miles across the mining district. The western extension of the anticline has been traced for 5 miles in Iowa and is 7 miles north of the Dubuque South quadrangle.

The structure contours shown on plate 1 are drawn on the top of the cherty unit of the Galena dolomite. This surface was chosen because it is conveniently located between most of the outcrop and subsurface data. The altitudes shown on the contours are in feet above mean sea level and have been determined by extrapolation to the top of the cherty unit from surveyed altitudes at outcrops and well collars. Intervals used for extrapolation have been determined by careful stratigraphic study of outcrops and subsurface data.

Many exposures of rocks of Silurian age that occur in the southern half of the quadrangle were used for structure control points after a detailed study of cuttings from 20 drill holes that were started in rocks of Silurian age and penetrated the Galena dolomite. Isopach maps of the Maquoketa shale and Edgewood dolomite (figs. 6 and 10) were made from this information and used in extrapolating to the top of the cherty unit of the Galena dolomite. The thickness of the noncherty unit of the Galena in the southern part 
of the quadrangle was established by the well at the Dubuque $\mathrm{Mu}$ nicipal Airport and the hole at the northeast corner of sec. $4, \mathrm{~T}$. 87, N., R. 2 E. (p. 84). Both holes penetrated the cherty unit and indicate a thickness of the noncherty unit similar to that elsewhere in the quadrangle.

\section{FOLDS}

Maximum structural relief in the Dubuque South quadrangle is 190 feet measured from the highest structural area at the northeast corner of the quadrangle to the lowest in sec. 2, T. $87 \mathrm{~N}$., R. 2 E., at the south edge of the quadrangle. This is about 19 feet per mile southwestward, nearly equaling the relief produced by the regional slope-an inclination of less than $1^{\circ}$. Except for many shallow folds, the beds lie nearly flat.

The structure contours in the northern half of the quadrangle have an amorphous pattern, and shallow amoeba-shaped third-order folds dominate the area (pl. 1). A few of the small folds indicated by 1 or 2 bluff outcrops possibly are surficial structures mapped from huge slumped blocks, but we carefully chose outcrops for use as structure control points in order to minimize this source of error.

A few of the third-order synclinal folds probably have been accentuated by subsidence over areas of carbonate-solution related to mineralization. The drill hole northeast ${ }_{\text {, of }}$ the North Fork of Catfish Creek and near the center of sec. 27, T. 89 N., R. 2 E. (p. 68), is in a basin in which rocks of the lower part of the Galena dolomite and the Decorah formation are 20 feet thinner than normal. This solution thinning, if widespread throughout the basin and accompanied by subsidence, would account for a large part of the structural relief of this basin.

Locally, beds dip toward mineralized joints because of subsidence over solution-softened rock along the joints, as seen in SW1/4 NE1/4 sec. 27 , T. 89 N., R. 2 E. (pl. 1). This phenomenon accounts for some dipping beds that do not conform to the structure contours.

Only one recognizable second-order anticline is known in the northern half of the quadrangle. The axis of this fold trends $\mathrm{S}$. $70^{\circ}$.W. from the north half of sec. 20, T. 29 N., R. 2 W., in Illinois, across the north halves of secs. 25 and 26, T. 89 N., R. 2 E., in Iowa. At the west edge of sec. 26 it turns abruptly southwestward and apparently disappears in the NE1/4 sec. 4 , T. 88 N., R. 2 E. The synclinal structure northwest of this fold and diagonally across secs. 27 and 33, T. 89 N., R. 2 E., is a second-order fold.

The southern half of the quadrangle has well-developed secondorder folds. The dominant fold is the anticline that extends from 
the NE1/4 sec. 17, T. 88 N., R. 3 E., southwestward parallel to the scarp face to sec. 28, T. 88 N., R. 2 E., where the fold apparently flattens. The axis of a syncline nearly as prominent as this anticline is 3,000 to 4,000 feet northwest of and parallel to the anticlinal axis. A syncline parallel to and southeast of these folds extends from the northern part of sec. 36, T. 88 N., R. 2 E., northeastward to the NW $1 / 4$ sec. 21, T. 88 N., R. 3 E. The structure contours in the upland south of the escarpment are less contorted than those of the rest of the quadrangle, partly because of sparse control points.

Trends of second-order fold axes range from N. $30^{\circ}$ to $70^{\circ} \mathrm{E}$. and average $\mathrm{N} .55^{\circ}$ to $60^{\circ} \mathrm{E}$. At places the configuration of the structure contours also suggests minor northwestward-trending cross folds.

\section{JOINTS}

Rocks in the Dubuque South quadrangle are well jointed; the joints are dominantly vertical. Many joints, although locally sinuous, have a uniform trend and can be traced for more than 1 mile. Joints have been widened by solution, and extensive cave systems have been formed in places. Kemling cave in the NE1/4 sec. 17, T. 88 N., R. 3 E., is an example of jointing that controls the formation of caves (fig. 2).

Figure 17 shows two diagrams of the strikes of 460 joints in rocks of Ordovician age and 108 joints in rocks of Silurian age. Dip diagrams are not shown because of a predominance of vertical joints. Each $5^{\circ}$ segment on the strike diagrams shows the average number of joints in that segment plus the two adjacent $5^{\circ}$ segments. Each diagram shows two major joint sets. The dominant set has an a verage strike of $N .87^{\circ} \mathrm{W}$, and the other has an average strike of N. $9^{\circ}$ E. The similarity of pattern for both diagrams indicates that the forces that produced jointing in the rocks of Ordovician age were not active until after Middle Silurian time. Therefore the uplift that ultimately produced the disconformity at the OrdovicianSilurian contact had no significant tectonic effect on the rocks.

These joint sets each strike about $45^{\circ}$ from the average axial trend of the second-order folds, about N. $55^{\circ}$ to $60^{\circ} \mathrm{E}$., in this quadrangle. We interpret this joint system as a conjugate system oriented in the shear direction of the folds. The eastward-striking set is predominant because apparently more shearing has taken place along these joints. The rocks along many of the joints in this set are brecciated and show minor slickensides but the offset was generally no more than a few inches. We believe the shearing along this joint set is due to the minor compressive force from the Forest City basin to the west operating simultaneously with the major compression directed north-northwest out of the Illinois basin. As the 

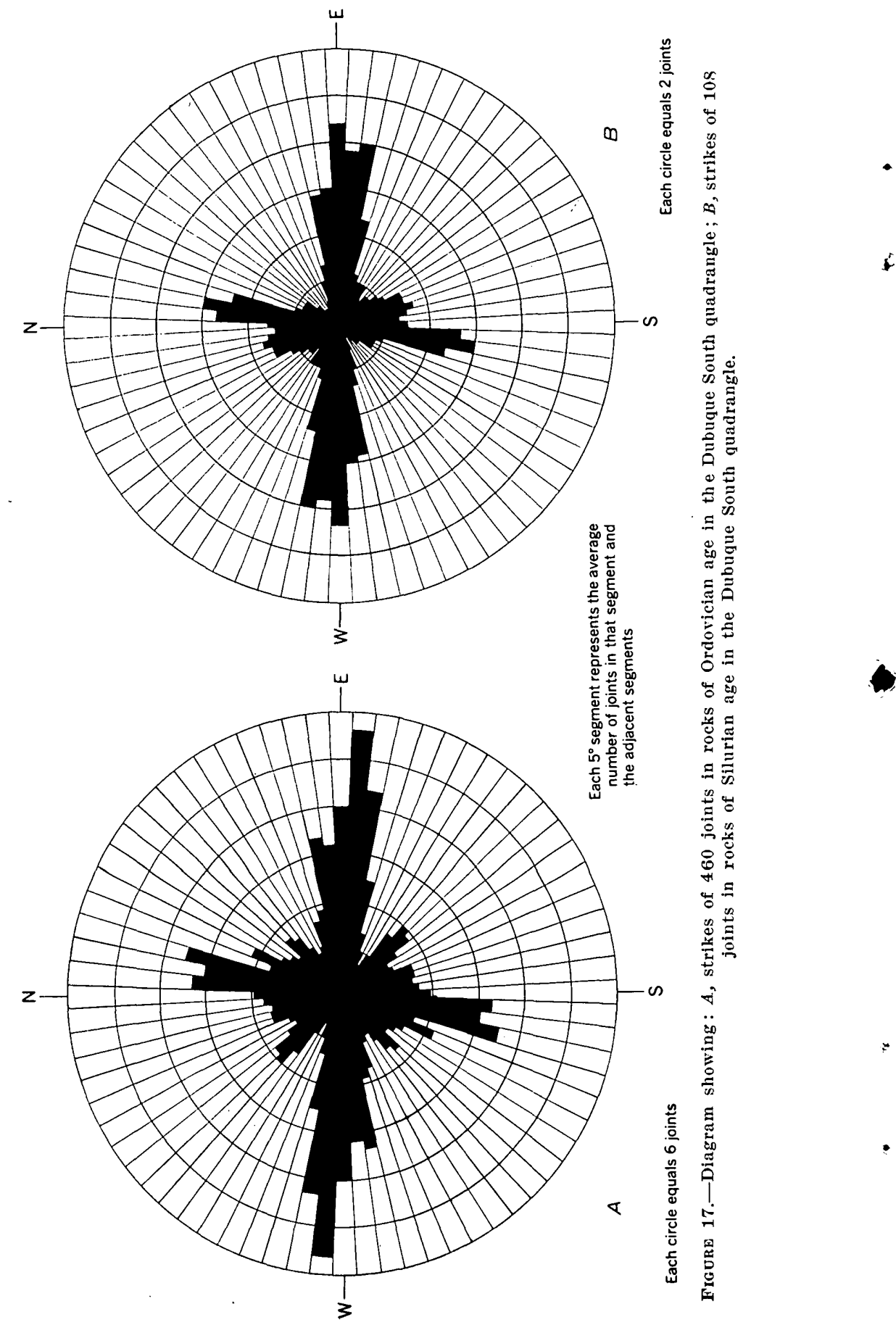

总

要

垔

壳

政

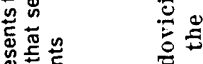

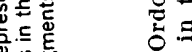

要密

党

$\Xi \Xi$

苞岇

莒

8

늠

is

空 
major force was folding the rocks and producing the conjugate joint system, the minor eastward-directed stress operating at a low angle to the eastward-trending joints was relieved by slight movement along many of them and by slight folding. These joints are parallel and closely spaced at many places, forming a shear zone. A single joint may bifurcate at a brittle stratum and join again, enclosing a slice of the brittle rock; as seen in the railroad cut at the southeast tip of the fractional sec. 31 , T. 89 N., R. 3 E.

Joints subordinate to the conjugate joint system strike in many directions but most of them strike northwestward. The northwestward-striking joints are interpreted as minor tension joints oriented normal to the axial plane of the second-order folds.

Minor inclined joints are locally common in dense brittle strata of the cherty unit of the Galena dolomite exposed in the northeastern part of the quadrangle. These joints are inclined more than $30^{\circ}$ from horizontal and commonly are clustered near fold axes. They dip generally toward an anticlinal axis.

\section{FAULTS}

Except for a few inches of shearing and displacement along some of the eastward-trending joints, faults were not observed in the Dubuque South quadrangle.

\section{ECONOMIC GEOLOGY}

LEAD AND ZINC

HISTORY AND PRODUCTION

Comprehensive accounts of early lead mining in Iowa were written by Calvin and Bain (1900,p. 480-489) and by Charles Keyes (1913, p. 89-116), and a similar account about the entire mining district was written by W. R. Ingalls (1908, p. 119-139).

The presence of galena in the mining district of Wisconsin, Illinois, and Iowa has been known since the middle of the 17th century. The first recorded mining was in 1690 when Nicolas Perrot, a French trader, built a lead furnace at a trading post near the present site of East Dubuque. Most of the mining was done by Indians who traded the ore for goods.

Mining continued sporadically until 1788 when Julien Dubuque; a French-Canadian, obtained exclusive mining rights from the Fox Indians to mine an area west of the Mississippi River from the Tete des Morts River to the Little Maquoketa River. This area includes most of the Dubuque South quadrangle. Julien Dubuque lived with the Indians at their village near the mouth of Catfish Creek. He built a lead furnace there and at least two more at the present site of the city of Dubuque. His men not only mined in 
Iowa but also east of the Mississippi River. Mining rights granted to Dubuque by the Indians were confirmed by the Spanish governor of Louisiana in 1796. Dubuque called these mines "the mines of Spain." Julien Dubuque died in 1810, and was buried by the Indians on a hill at the mouth of Catfish Creek where a historical monument marks his grave.

The amount of galena mined by Dubuque is not known; however, as much as 200 tons of metallic lead per year was shipped to St. Louis by Dubuque and his agents (Keyes, 1913, p. 98).

Indians continued to operate the lead mines in Iowa after Dubuque's death. They sold the galena to white men who had built a smelting furnace on one of the islands opposite the mouth of Catfish Creek. The Fox Indians continued mining until about 1820, when white men began to mine near Dubuque. However, the land west of the Mississippi River was not open for settlement, and these miners were driven out by Federal troops in 1830 . This area was opened for settlement at the close of the Black Hawk War in 1833, and lead mining was resumed by settlers from Illinois and Wisconsin. Lead mining increased steadily from 1833 to 1845 , but output leveled off from 1847 to 1857 . After 1857, except for brief periods, lead production declined until 1910 when the principal mines were closed. Sporadic operation of a few small mines has produced a small amount of galena since 1910.

Zinc ore was mined in Wisconsin and Illinois as early as 1859, but was first mined in Iowa late in the 1870's. The ore was smithsonite and came mainly from mines in Dubuque and some of those in sec. 33, T. 89 N., R. 2 E. The production of smithsonite surpassed that of galena in 1880 .

Sphalerite was first mined in Iowa from the Alpine mine in 1898; from 1906 to 1908 more sphalerite was mined than either smithsonite or galena. Zinc ore was last mined in Iowa in 1910. In 1916-17, 39 tons of metallic zinc was recovered from ore in mine dumps at the Beadle and Brugh mines.

Production figures for zinc and lead ore are in the Annual Reports of the Iowa Geological Survey for 1895-1917. These reports show a total tonnage of 3,990 tons of galena, 9,830 tons of smithsonite concentrate, and 1,265 tons of sphalerite concentrate. Some of the zinc ore was mixed smithsonite and sphalerite, therefore the tonnages of types of zinc ore are approximate. Most of this production came from mines in the Dubuque South quadrangle.

Accurate statistics for lead and zinc production are not available for the individual mines in Iowa, but estimated figures for production of galena from a few gash veins in the Dubuque South quadrangle have been included in geological reports on the Iowa part of the zinc-lead district (table 1). 
TABLE 1.-Reported production of galena from gash veins in the Dubuque South quadrangle

\begin{tabular}{l|l|c}
\hline Name & Location & $\begin{array}{c}\text { Galena } \\
\text { (short tons) }\end{array}$ \\
\hline
\end{tabular}

T. 89 N., R. 2 E.

\begin{tabular}{|c|c|c|}
\hline Black crevice ${ }^{1}$ & $\mathrm{~N} 1 / 2$ secs. 25 and 26 . & 750 \\
\hline Faulkner ${ }^{1} \ldots \ldots$ & N1/2 sec. $25 \ldots$ & 1,000 \\
\hline Langworthy ${ }^{1}$ - & $\mathrm{S} 1 / 2 \mathrm{~N} 1 / 2$ secs. $25,26,27$ & 3,000 \\
\hline Kelly ${ }^{2} \ldots \ldots$ & . do & 5,000 \\
\hline Madden $23 .-$ & $\mathrm{N} 1 / 2 \mathrm{~S} 1 / 2$ sec. $25 \ldots$ & 1,000 \\
\hline Slater ${ }^{2} \ldots \ldots$ & $\mathrm{N} 1 / 2 \mathrm{~S} 1 / 2$ secs. $25,26,27 \ldots$ & 1,000 \\
\hline MeKenzie 2-.- & SW1/4 sec. $25 \ldots$ & 500 \\
\hline Ames ${ }^{23} \ldots \ldots$ & $\mathrm{N} 1 / 2 \mathrm{NE}_{1}^{1} / 4$ sec. 35 & 1,000 \\
\hline Pikes Peak mines ${ }^{1} \ldots \ldots$ & $\mathrm{SE} 1 / 4$ sec. 33 & 6,025 \\
\hline
\end{tabular}

T. 88 N., R. 2 E.

Kane mine ${ }^{4} \ldots \ldots \ldots \ldots \mid$ NW1/4 sec. $12 \ldots \ldots \ldots$

T. 88 N., R. 3 E.

\begin{tabular}{l|l|l|}
\hline Fessler mine ${ }^{5} \ldots \ldots \ldots \ldots$ & NE $1 / 4$ sec. $6 \ldots \ldots \ldots \ldots \ldots$ & $50+\ldots$ \\
\hline
\end{tabular}

1 Calvin and Bain $(1900$, p. 530-565).

2 Dubuque Daily herald (Nov. 20, 1864).

3 Whitney $(1858$, p. 456)

4 James E. Kane, Rockdale, Iowa (written communication, 1955).

$\checkmark$ Dubuque Daily T'imes (Oct. 27, 1907).

\section{JOINT-CONTROLIED DEPOSITS}

The lead and zinc ore mined in the Dubuque South quadrangle was from veins in solution-widened vertical and steeply dipping joints. These mineralized joints were named crevices by the early miners, and closely spaced parallel crevices were named ranges. Whitney (1858, p. 432) named the deposits gash veins to distinguish these stratigraphically restricted deposits from common fissure veins.

The deposits are confined to the Galena dolomite, and their localization was controlled by three factors: (a) stratigraphic zones of greater solubility owing either to chemical composition or to greater permeability and grain size than adjacent strata; (b) welldeveloped steeply dipping shear joints intersecting these zones; and (c) intersections of joints. The major eastward-trending joint set of the conjugate joint system (see section "Joints") is most commonly mineralized. Aqueous solutions in the joints dissolved the wallrock selectively before mineralization. The cavities or porous 
spongelike zones produced in the most soluble strata are named openings by local miners. These openings are shown in plate 3 at their normal stratigraphic position. Where a major eastwardtrending joint is crossed by another joint, the wallrock is generally extensively dissolved, producing cavities or chimneys at the intersection. These open spaces were selectively mineralized by later lead- and zinc-bearing solutions. Therefore the joint-controlled deposits are podlike both vertically, because of stratigraphic control, and laterally, because of control by joint intersections. Many parallel gash veins are closely spaced and the associated mineralized rock locally coalesces (pl. 4).

Where erosion has exposed the gash-vein deposits to oxidizing conditions near the ground-water table, sulfide minerals are dissolved, and the metallic components are partly redeposited as new compounds. Iron from iron sulfide forms hydrated iron oxides. Zinc from sphalerite is redeposited as zinc carbonate and a small amount of zinc silicate. Lead sulfide is altered in place to lead carbonate which forms an insoluble armor on galena, protecting it from further alteration.

Dolomite, which is the wallrock of the gash-vein deposits, is softened and partly dissolved because of intergranular corrosion by ground water made acidic by the oxidation of sulfide minerals. Oxidation and partial removal of pyrite and marcasite also helps soften the dolomite because they are finely disseminated in the wallrock and help cement it. This softening and dissolving of the wallrock is confined mainly to opening zones as was the initial forming of the open spaces by solutions preceding mineralization. As alteration of the rock by ground water continues, support is removed for the vein and some of the wallrock and they collapse. Consequently, the opening is partly filled with dolomite boulders, pieces of galeni, dolomite sand, and clay that is a residue from the dissolved dolomite. These are called tumble openings by local miners. Commonly a stratified deposit of silt, clay, and sand lies on top of the collapsed material and completely fills the opening. Much of this material came down the joint from the surface, indicated by depauperate fossils from the Maquoketa shale, glacial material, and chert fragments from Silurian rocks.

As the ground-water table descends below the filled openings, moving water in the vadose zone partly excavates the joint-filling material and forms calcareous cave deposits on the wallrock. Chunks of galena from the excavated fill are concentrated on the cave floor.

Residual deposits of galena occur in the soil zone where weathering has removed the wallrock of a vein. These deposits are exposed in gullies and ravines by erosion. Many prominent mineral- 
ized joints were found because of their residual deposits, and many of the shallow pits in the Dubuque South quadrangle were dug for residual deposits of galena (pl. 4).

Veins were not necessarily confined to the opening zones but commonly were richer at these places. The lead ore mined at the Kane mine at Key West was above the first opening in the Galena dolomite, close to the base of the Maquoketa shale. Deposits near the center of sec. 27 , T. 89 N., R. 2 E., and north of U.S. Highway 20 in the SW1/4 sec. 26, T. 89 N., R. 2 E., are also near the base of the Maquoketa shale.

Galena and sphalerite can occur in the same mineralized joint, but they are rarely present as mixed ore. Galena is generally in openings stratigraphically higher than those containing sphalerite. This seems to be vertical zoning, but possibly the sphalerite filled the lower openings, which are generally porous, spongelike zones. Consequently, the main open space remaining for deposition of galena was in the first opening (pl. 3) which was more cavernous. This apparent zoning also occurs laterally along a mineralized joint. Galena occurs mainly at solution-widened joint intersections and sphalerite occurs mainly in the porous rock of the opening zone between joint intersections.

More galena was mined from the first opening zone (see pl. 3) in the Dubuque South quadrangle than from any other opening zone, and possibly more than from all other opening zones. This is partly because the first opening zone is exposed at many places in the northern half of the quadrangle and is easily accessible for: mining. Also, it is apparently more heavily mineralized with galena than the other opening zones.

Smithsonite was mined from gash veins in Dubuque and at the mines in the SE1/4NE1/4 sec. 33, T. 89 N., R. 2 E., and sphalerite was mined from opening zones below the water table in several of the mines in Dubuque and in the SE1/4 sec. 33, T. 89 N., R. 2 E. The Avenue Top, Goosehorn, Alpine, Beadle, and Brugh mines produced sphalerite. The main stratigraphic zone mined was the top opening of the double upper flint opening zone (see pl. 3). This zone was reached in the Beadle and Brugh mines and possibly in the Avenue Top mine. Galena deposits were mined from the upper openings of these mines.

\section{PITCH-AND-FLAT DEPOSITS}

The largest zinc ore deposits mined in Wisconsin and Illinois are pitch-and-flat deposits (pl. 4). This type of deposit has not been found in the Dubuque South quadrangle. Pitches are inclined veins filling minor reverse faults. Flats are veins along bedding surfaces 
and are closely associated with and connected to pitches. Where known from mines in the Wisconsin and Illinois part of the mining district, these deposits occur in the Decorah formation and lower part of the cherty unit of the Galena dolomite.

Pitches commonly occur closely spaced, forming a pitch zone. Flats generally are in the footwall of the deposits and have disseminated sulfide minerals known as core ground. Pitch-and-flat deposits vary widely in shape. The typical deposit has two pitches with nearly parallel strikes and divergent dips (pl. 4) and join at one end to form a horseshoe-shaped deposit. These are called arcuate double pitch deposits. Deposits having a single pitch are also common. Generally the pitch fractures are curved and some have very sinuous trends.

A. V. Heyl, Jr., and others (1959) studied many of these deposits in Wisconsin and concluded that the pitch fracture originates as a bedding-plane fault in the shaly Decorah formation. These faults are deflected upward as thrust faults through overlying rock and die out either along vertical joints or at well-defined bedding surfaces (pl. 4). This thrusting produced open spaces along bedding surfaces in the hanging wall of the fault. Later solution thinning of the rocks has allowed settling and formation of open spaces at the fault and at bedding surfaces because of differential settling of the beds. The opened cracks, if mineralized, are the pitches and flats.

Another hypothesis for the origin of the fracture of the pitchand-flat deposits is mineralization stoping. Carbonate solution is intimately associated with pitch-and-flat deposits. Solution thinning of limestone strata in closely jointed zones removed support for overlying rocks, which consequently collapsed along an irregular domelike fracture system forming a natural arch. These fractures where mineralized are the pitches and flats.

Reynolds (1958) related the thickness of mineralized rock to the amount of solution thinning in 1,000 exploratory drill holes near Shullsburg, Wis. He found a direct relation and used that as evidence that collapse of the rocks and consequent production of open fractures was greater in areas of more intense solution thinning.

Pitch-and-flat deposits undoubtedly occur in Iowa, but have not been found, primarily because the Decorah formation has not been extensively explored by drilling. Secondly, the mines in Iowa did not reach the zone of pitches and flats, although inclined mineralized fractures were reported at the Avenue Top and Alpine mines. Thirdly, these deposits have not been found by chance in drilling wells because sufficient water is obtained from strata above the potentially mineralized zone. Nevertheless, low-grade mineralized 
rock and associated alteration was found in 1952-53 in drilling near Durango, Iowa, by a private company and also in drilling for the U.S. Geological Survey in the same area (Flint and Brown, 1956). The hole near the center of sec. 27, T. 89 N., R. 2 E., also penetrated similarly altered and mineralized rock (p. 68). This drilling further supports the premise that the Decorah formation and the lower part of the Galena dolomite contain zinc and lead deposits in Iowa.

\section{MINERALOGY OF DEPOSITS}

The minerals of the lead and zinc deposits are sulfides, carbonates, and rarely sulfates. Galena and sphalerite are sulfides and are currently the only lead and zinc minerals of commercial importance. Deposits of smithsonite were mined in the Dubuque South quadrangle from the late 1870's to 1910. Smithsonite was commercially important as a source of zinc oxide.

Galena occurs as veins or as crystals on the walls of cavities. It generally fills open spaces and rarely replaces the wallrock. Crystals of galena are cubes as much as 8 inches on a side. Commonly the cubes are modified by octahedral faces as was the galena mined at the Kane mine near Key West.

Large cubes of galena are locally known as cog lead and small cubes are known as dice lead. Veins in the oxidized zone commonly disintegrated after the wallrock was softened or removed, and the galena is in the debris-filled cavity as irregular pieces known locally as chunk lead. Some of these chunks weighed as much as 20 tons. Cerrusite occurs as a bluish-gray scale on galena in oxidized deposits. The scale armors the galena from further corrosion.

Sphalerite below the water table in the gash-vein deposits of the Dubuque South quadrangle generally occurs as aggregates of crystals filling the vugs of rock made porous by solution. Commonly the rock had become so porous that it crumbled, forming a solution breccia. Mineralized breccia and mineralized vuggy rock is known locally as brangle ore. It was observed on the dumps of the Beadle, Brugh, and Lockey Drybone mines in sec. 33, T. 89 N., R. 2 E. Sphalerite partly replaces the host rock of brangle ore and also locally forms colloform banded veins in gash-vein deopsits.

Sphalerite is the principal vein mineral in pitch-and-flat deposits. It also occurs as small disseminated crystals which partly replace the host rock in the core ground. Veins of sphalerite have colloform banding and crystalline inner surfaces. The crystals are distorted dodecahedrons.

In the pitch-and-flat deposits of Wisconsin and Illinois, galena is mixed with the sphalerite but is most commonly found as crystals in the top flat, which is generally more open than the other flats. The lead to zinc ratio in this type of deposit is approximately 1 to 9 . 
Smithsonite is the alteration product of sphalerite in the zone of oxidation at and above the water table. Porous pseudomorphs of smithsonite after sphalerite with sphalerite cores were seen in the Lockey Drybone mine and in the road cut near the west edge of sec. 33 , T. 89 N., R. 2 E. Three veins of smithsonite are exposed in this roadcut. Most smithsonite has a hackly cellular texture resembling the interior of dried bones; hence the name drybone. Locally it is also known by miners as honeycomb bone. Cellular smithsonite is mainly a result of zinc carbonate deposition on the surface of sphalerite and along many slightly opened cleavage surfaces of the mineral as it is being corroded by ground water. Another form of smithsonite, known locally as rock bone, occurs as massive finely porous fracture fillings. This type is a result of transportation and redeposition by ground water. The cellular variety is a result of alteration in place. Smithsonite is commonly stained by limonite.

The occurrence of zinc silicate has been noted in the mining district. Small acicular crystals on some of the smithsonite at the Lockey Drybone mine in the NE1/4 of sec. 33 , T. 89 N., R. 2 E. may be hemimorphite.

Marcasite and pyrite are commonly associated with sphalerite and less commonly with galena deposits. Well-formed pyrite octahedrons occur with galena on the mine dump of the Sloan shaft 1 mile north of the Dubuque South quadrangle in NE1/4 sec. 21, T. 89 N., R. 2 E. Cuttings from drill holes in this section show an average of 16 percent iron sulfide through 40 feet of Galena dolomite. Drusy marcasite forms a lining in many of the vugs in rocks on the Beadle mine dump. Above the water table iron sulfide has been oxidized to limonite or ocher, which stains the rock near gash-vein deposits.

Manganese oxide, pyrolusite or wad, is common in some of the oxidized gash-vein deposits in the Dubuque South quadrangle. In the western part of the Lockey Drybone mine it occurs locally as a sooty deposit on smithsonite. The Black Crevice in Dubuque gets its name from the abundant manganese oxide associated with smithsonite. The origin of the manganese is unknown because primary manganese minerals have not been found in this district. The manganese may be in the crystal lattice of the sphalerite, as some sphalerite is colored violet.

Black, gray, or brown waxy clay is common in oxidized jointcontrolled deposits. Some of this clay was identified as zincian montmorillonite and sauconite (Ross, 1946).

Calcite is a common accessory mineral and occurs as crystals in vugs or as veins. The Galena dolomite in the NE1/4 sec. $36, \mathrm{~T} .89 \mathrm{~N}$., R. 2 E., has numerous veinlets of calcite, apparently not associated with zinc or lead mineralization. 
The paragenetic relation of the minerals deposited in gash veins was generally in the following order, with some overlap of the stages: pyrite and (or) marcasite, sphalerite, galena, and a late stage of pyrite and (or) marcasite. Calcite and possibly barite deposition followed the sulfide mineralization. Most gash veins contain galena, sphalerite, iron sulfides, and calcite. Some veins contain only galena and a small amount of iron sulfide, and other joints having welldeveloped solution openings contain only calcite and pyrite. Lack of complete mineral suites in joints possibly indicates that tectonism was active while mineralization was taking place and these joints were formed or made accessible to mineral-bearing solutions in the late stages of the paragenetic sequence of mineralization.

Barite is common in some of the pitch-and-flat deposits of Wisconsin and Illinois. We have not seen barite associated with the gash-vein deposits in the Dubuque South quadrangle, but it is common and widespread in the brown shaly unit of the Maquoketa shale and less commonly occurs in the upper beds of the Galena dolomite. It has been found in this zone in some of the holes drilled for the U.S. Geological Survey in the Dubuque South quadrangle (see p. 68 ). These occurrences are possibly above areas of mineralization in underlying strata. The barite occurs either as radiating white crystalline masses or as clear platy crystals as long as 4 inches. Crystals generally are basal orthorhombic plates exhibiting several modifying faces. Overgrowths are common on the prism faces. Some barite crystals seen from the excavation for the overpass at Grandview Avenue and U.S. Highways 151, 61, and 52 have reticulated needles of a brassy-yellow mineral, possibly millerite, included in them.

Barite also occurs as one-half-inch crystals in vugs of the upper member of the Edgewood dolomite in the quarry along the road in sec. 4, T. 88 N., R. 2 E. Here the crystals are clear and have white overgrowths.

Malachite and chalcopyrite were reported in the ore at the Beadle mine. Small grains of chalcopyrite partly oxidized to malachite are included in barite found in the Maquoketa shale near the center of sec. 13 , T. 88 N., R. 2 E.

Pyrite, marcasite, sphalerite, galena, and barite commonly occur in the rock near the Galena dolomite-Maquoketa shale contact. The drill hole near the center of sec. 24 , T. 88 N., R. 2 E. (p. 78). penetrates rock that is heavily mineralized with iron sulfide and has sphalerite, galena, and barite.

\section{STRATIGRAPHYC AND STRUCTURAL CONTROLS}

Control of the gash veins is included in the discussion of jointcontrolled deposits (p. 53). The main deposits are confined to cer- 
tain strata of the Galena dolomite which were made cavernous or porous by solution along joints. The principal openings are shown in plate 3.

Pitch-and-flat deposits known from mines in Wisconsin and Illinois are controlled stratigraphically in that they are mainly in the Decorah formation, in the lower part of the cherty unit of the Galena dolomite, and in the upper part of the Platteville formation.

Although the relation between folding and jointing is clear, that of individual folds to areas of mineralized joints is very vague. The geologic map (pl. 1) shows a general concentration of mining in anticlinal areas, particularly along the anticline extending southwestward from sec. 25 , T. 89 N., R. 2 E. through the SE1/4 sec. 33, T. $89 \mathrm{~N}$., R. $2 \mathrm{E}$. If the actual extent of mineralized rock along joints were known a better correlation between folding and the occurrence of gash veins might be possible. One means of determining the extent of mineralized rock at present is by the location of mines and prospects. They are not good indicators of the actual linear extent of the mineralized joints because deposits were found by the early miners mainly where erosion, by chance, exposed the deposits. Mining many times was not continued to the end of mineralized rock but to the point where mechanical problems made the deposits uneconomical to mine. Therefore, many mineralized joints that have no surface expression probably exist in areas covered by Maquoketa shale and rocks of Silurian age.

The correlation between pitch-and-flat dposits and structure in the Iowa part of the mining district is not possible at present because deposits of this type have not been located. A correlation in Wisconsin and Illinois is that the deposits are generally closer to the axes of second- or third-order synclines and basins than to the axes of anticlines (Heyl and others, 1955, p. 235). Deposits also commonly occur at the intersection of folds. These correlations are assumed to be applicable in Iowa also. Mineralized and altered rock was found in the pitch-and-flat zone in basins near Durango, Iowa (Flint and Brown, 1956), and also in the basin near Center Grove, Iowa (p.68).

\section{WALLROCK ALTERATION}

Galena dolomite that is wallrock of gash-vein deposits has been altered not only by the solvent action of aqueous solutions, before and during mineralization, but also later by ground water near the water table (see "Joint-controlled deposits"). Early aqueous solutions made cavities which were subsequently mineralized and also caused disintegration of the dolomite by intergranular corrosion. Ground water has similarly altered the wallrock of deposits near the water table. The alteration by ground water caused disintegra- 
tion of the wallrock and veins and produced openings filled with dolomite boulders, dolomite sand, galena, clay and silt.

Dolomitization, silicification, and carbonate leaching along with consequent compaction of the shaly residues, are alteration processes associated with pitch-and-flat deposits in Wisconsin and Illinois.

Dolomitization has altered the limestone beds in the Decorah formation and the McGregor limestone and Quimbys Mill members of the Platteville formation near pitch-and-flat deposits. These beds are normally very fine grained limestone. Dolomitization produces a sugary texture and slight color changes. Silicification alters the same strata affected by dolomitization but is less common and is less obvious than other forms of alteration. The texture of the rock is only slightly different from unaltered rock. The strata of the Decorah formation are altered by solution of the limestone and compaction of the shale partings and insoluble residues. All three alteration effects are found in the Decorah formation in the Iowa part of the lead-zinc district outside the Dubuque South quadrangle (Flint and Brown, 1956). Altered rock of the Decorah formation in the quadrangle was observed only in cuttings from the drill hole in sec. 27 , T. 89 N., R. 2 E. (p. 68). Here the Guttenberg limestone member of the Decorah formation is half its normal thickness and comprises dolomitic limestone and brown shale.

\section{GUIDES TO ORE}

The most significant guides to ore in gash veins are the trends shown by alinement of prospects and shafts. The ore from all but a few mines came from above the water table, and mineralized rock below the water table is generally unmined. Very few gash veins were mined beneath the Maquoketa shale because the mineralized strata were too deep for mining methods used before 1910. Also, the shale is wet and caves readily so that sinking shafts through it is difficult. Therefore, rock along the projection of the strike of a mineralized joint probably contains ore below the Maquoketa shale.

Limonite-stained rock and residual soil may also be a possible guide to ore, but much of the till, gravel, and residual soil in the Dubuque South quadrangle is stained by limonite unrelated to lead-and zinc-mineralized areas.

Chert in the Galena dolomite is selectively mineralized by fine disseminated iron sulfide which gives the chert a dark color. Darkened chert is noticeable in rock cuttings from some drill holes as well as in some outcrops and is a guide to mineralized zones.

Rock alteration associated with the pitch-and-flat deposits in Wisconsin and Illinois has been a successful guide to mineralized areas. These effects are noticeable in both outcrops and rock cuttings from drill holes. 
The flanks of basins and synclines, and the intersections of folds are more favorable places for the occurrence of pitch-and-flat deposits than are the crests of anticlinal areas. Also, areas of shallow lead diggings commonly are in the vicinity of the stratigraphically lower pitch-and-flat deposits in Wisconsin and Illinois.

Systematic sampling of the residual soil and chemical analysis for lead and zinc have been used successfully in other mining districts to locate areas over mineralized rock. This method has been tried in this district (Kennedy, 1956) with moderately successful results.

Agnew (1955a) discusses the application of geologic principles to finding ore in the Wisconsin-Illinois-Iowa mining district.

\section{DESCRIPTIONS OF MINES}

Some mines in gash-vein deposits included in the Dubuque South quadrangle are described by Calvin and Bain (1900) and by Leonard (1897). Most of the mines are inaccessible at present, and only three abandoned mines were mapped during this investigation. Maps and cross sections of these mines show the characteristic form of gash-vein deposits.

The East and West Lockey Drybone mines (pls. 5 and 6) are on the same mineralized joint. These mines, in the third opening zone, apparently contained a small quantity of galena but were strongly mineralized with sphalerite that is altered to smithsonite. The ore as a mineralized brangle (see p. 57) was continuous along the joint and extended as much as 5 feet into the wallrock in the selectively mineralized beds. Near the west end of the West Lockey mine, mineralized rock disappears along the main joint, and reappears along a parallel joint 20 feet to the north. Most of the mine walls show mineralized rock, but the extreme west end of the deposit is in barren rock. The prospect shaft at the east end of the West Lockey mine (pl. 6) was sunk below the water table into the cherty unit of the Galena dolomite. Here the sphalerite was unaltered, and the ore is a solution breccia rich in sphalerite, as indicated by material on the dump.

Inaccessible workings are a quarter of a mile east of the East Lockey Drybone mine on the same trend. Smithsonite is on the dumps of these workings.

The Royce and Frost mine (pl. 7), located east of Hill Street in the NW1/4 sec. 25, T. 89 N., R. 2 E., was worked for smithsonite and galena. 'The smithsonite occurred mainly as a vein of massive smithsonite called rock bone by local miners. 'The vein fills a joint that trends about $\mathrm{N} .80^{\circ} \mathrm{W}$, and mineralized chimneys characteristic of gash-vein deposits are at joint intersections. The main joint 
shows minor vertical displacement having the north wall dropped a few inches. This mine is in the second opening zone and is on the eastern extension of the Avenue Top or McNulty crevice, from which galena, sphalerite, and smithsonite were mined.

\section{NONMETALLIC DEPOSITS}

\section{DOLOMITE AND LIMESTONE}

The Galena dolomite and dolomite of Silurian age is commonly crushed for road gruvel. The noncherty Hopkinton dolomite and Galena dolomite are also suitable for agricultural lime but have not been quarried extensively in this quadrangle for that purpose.

Dimension stone has been quarried from the lower 20 feet of the Dubuque shaly member of the Galena dolomite at several quarries along Dodge Street in Dubuque and the south-facing valley wall in the NW1/4 sec. 35, T. 89 N., R. 2 E. The basal 8 feet of the Kankakee formation is also an excellent building stone and has been quarried for foundation stone at many small pits along the escarpment.

\section{CLAY}

The Brainard member of the Maquoketa shale contains much clay which is plastic, soft, and easily accessible along the front of the Niagaran escarpment. This clay could possibly be used by the ceramic industry or as a paint filler. We know of no places where clay from the Brainard member is used commercially, although amateur ceramicists have used clay from outcrops along the Tete des Morts River for use in home kilns (R. J. Reiss, oral communication, 1956).

\section{SAND AND GRAVEL}

Sand and gravel from the alluvial fill in the Mississippi River: valley floor are dredged at Dubuque. The alluvial fill is as much as 337 feet thick.

Stream-channel deposits of chert gravel occur in valleys topographically below the outcrop areas of cherty dolomites of Silurian. age. These deposits are dug from the valley of the Tete des Morts River in the Dubuque South quadrangle and from Granger Creek in the NEY/4 sec. 23 , T. 88 N., R. 2 E. They are used locally for gravel roads and for subbase material in highway construction. Chert gravel is not usable for concrete aggregate because chert hydrates and causes disintegration of the concrete.

\section{Phosphate}

The basal 2 to 4 feet of the Maquoketa shale is highly phosphatic. The rock is very crumbly and is almost entirely composed of small 
phosphatic fossils, thin beds of fine phosphatic pellets, and pebbles. Although thin, it is potentially a source of phosphatic material.

\section{GROUND WATER}

The water supply of the city of Dubuque is now obtained from shallow wells penetrating alluvial gravels of the Mississippi River. These wells are located about 2 miles north of this quadrangle area. The municipal water supply formerly came from deep wells (see "Precambrian and Cambrian systems") in which the Dresbach sandstone of Late Cambrian age is the most important aquifer. The change to the shallow source of water supply was completed in 1957 ; the deep wells are kept on a standby basis.

A few industries in Dubuque continue to use deep wells penetrating the same aquifers previously used by the city. Many industries obtain water from shallower wells in which the Galena and St. Peter formations and Prairie du Chien group are the important aquifers.

Most farm and residence wells in the area in which the Maquoketa shale and Galena dolomite are bedrock derive their water from the lower part of the Galena dolomite. The Galena is a good aquifer because it is well jointed.

Wells in the area in which dolomitcs of Silurian age are bedrock obtain ground water from those rocks except in a zone that extends about 1 mile sonth of the northern edge of the Niagaran cuesta. Ground-water level in rocks of Silurian age in this zone is low because the water flows out along the escarpment at springs at the upper contact of the Maquoketa shale. Wells in this zone are commonly drilled into the Galena dolomite or the brown shaly unit of the Maquoketa shale in order to get sufficient water. The Dubuque Airport well, also in this zone, gets water from the St. Peter sandstone. South of this zone wells are generally less than 150 feet deep, and some farms use springs for their water supply.

In the Dubuque South quadrangle water from the Silurian dolomite is commonly lost in wells that are continued through the Maquoketa shale and into the underlying Galena dolomite because of the lower head in the Galena. On the other hand, the water level in a farm well near the center of sec. 2, T. 87 N., R. 2 E., rose to within 90 feet of the land surface when the Galena was penetrated. This phenomenon is due to structural and perhaps other factors. The well is in a syncline.

\section{LITERATURE CITED}

Agnew, A. F., 1955a, Application of geology to the discovery of zinc-lead ore in the Wisconsin-Illinois-Iowa district: Mining Eng., v. 7, no. 8, p. 781-795. 1955b, Facies of Middle and Upper Ordovician strata in Iowa: Am.

Assoc. Petroleum Geologists Bull. v. 39, no. 9, p. 1703-1752. 
Agnew, A. F., Flint, A. E;, and Allingham, J. W., 1953, Exploratory drilling program of U.S. Geological Survey for evidence of zinc-lead mineralization in Towa and Wisconsin, 1950-51: U.S. Geol. Survey Circ. 231, 37 p.

Agnew, A. F., Heyl, A. V., Jr., 1946, Quimbys Mill, new member of l'latteville formation, Upper Mississippi Valley: Am. Assoc. Petroleum Geologists Bull., v. 30 , p. $1585-1587$.

Agnew, A. F., Heyl, A. V., Jr., Behre, C. H., Jr., and Lyons, I. J., 1956, Stratigraphy of Middle Ordovician rocks in the zinc-lead district of Wisconsin, Illinois, and Iowa: U.S. Geol. Survey Prof. Paper 274-K, p. 251-312.

Bain, H. F., 1905, Zinc and lead deposits of northwestern Illinois: U.S. Geol. Survey Bull. 246, 56 p.

1906, Zinc and lead deposits of the upper Mississippi Valley: U.S. Geol. Survey Bull. 294, 155 p.

Brown, C. E., Whitlow, J. W., and Crosby, Percy, 1957, Geology and rinc-lead deposits in the Catfish Creek area, Dubuque County, Iowa: U.S. Geol. Survey Mineral Inv. Field Studies Map MF 116.

Calvin, Samuel, 1898, Geology of Delaware County: Towa Geol. Survey Ann. Rpt., v. 8, p. 119-192.

1906a, Geology of Winneshiek County: Iowa Geol. Survey Ann. Rpt., v. 16, p. $39-146$.

$1906 \mathrm{~b}$, Notes on the geological section of lowa: Jour. Geology, v. 14, p. 571-578.

Calvin, Samuel, and Bain, H. F., 1900, Geology of Dubuque County: Towa Geol. Survey Ann. Rept., v. 10, p. 379-622.

Chamberlin, T. C., 1877, Geology of eastern Wisconsin: Wisconsin Geol. Survey, Geology of Wisconsin, Survey of 1873-79, v. 2, p. 91-405.

1883, General Geology of Wisconsin: Wisconsin Geol. Survey, Geology of Wisconsin, Survey of $1873-79$, v. 1., p. 3-300.

Chamberlin, T. C., and Salisbury, R. D., 1885, Preliminary paper on the Driftless Area of the Upper Mississippi Valley: U.S. Geol. Survey Sixth Ann. Rpt. 1884-85, p. 199-322.

Flint, A. E., 1956, Stratigraphic relations of the Shakopee dolomite and the St. Peter sandstone in southwestern Wisconsin: Jour. Geology, v. 64, no. 4, p. $396-421$.

Flint, A. E., and Brown, C. E., 1955, Geology and zinc-lead deposits in the Durango area, Dubuque County, lowa: U.S. Geol. Survey Mineral Inv. Map MF 33.

- 1956, Exploratory drilling for evidence of zinc and lead ore in Dubuque County, Iowa: U.S. Geol. Survey Bull. 1027-K, p. 471-499.

Fall, James, 1851, Lower Silurian system, in Foster, J. W., and others, Geology of Lake Superior land district: U.S. 32d Cong., Spec. sess., Senate Ex. Doc. 4 , p. 140-166.

Hershey, O. H., 1894, The Elk Horn Creek area of St. Peter sandstone in northwestern Illinois: Am. Geologist, v. 14, p. 169-179.

Heyl, A. 'ं., Jr., Agnew, A. F., Behre, C. H., Jr., Lyons, E. J., and Hershey, H. G., 1945, Geologic map of the Center Grove-Pikes Peak area, Dubuque County, Iowa: U.S. Geol. Survey Strategic Min. Inv. Prelim. Map 3-203.

Fleyl, A. V., Jr., Agnew A. F., Lyons, E. J., and Behre, C. H., Jr., 1959, The Geology of the Upper: Mississippi Valley zinc-lead district: U.S. Geol. Survey Prof. Paper 309, 310 p.

Heyl, A. V., Jr., Lyons, E. J., Agnew, A. F., Behre, C. H., Jr., 1955, Zinc-leadcopper resources and general geology of the Upper Mississippi Valley district: U.S. Geol. Survey Bull. 1015-G, p. 227-245. 
Howell, J. V., 1916, An outlier of the so-called Clinton formation in Dubuque County, Iowa: Iowa Acad. Sci. Proc. 23, p. 121-124.

Ingalls, W. R., 1908, Lead and zinc in the United States: New York, Hill Pub. Cu., $368 \mathrm{p}$.

Kay, G. M., 1928, Divisions of the Decorah formation: Science, new ser., v. 67 , pt. 1, p. 16.

1935a, Ordovician system in the upper Mississippi Valley: Kansas Geol. Soc. Guidebook 9th Ann. Field Conf., p. 281-295.

1935b, Distribution of Ordovician altered volcanic materials and related clays: Geol. Soc. America Bull., v. 46, p. 225-244.

Kennedy, v. C., 1956, Geochemical studies in the southwestern Wisconsin zinclead area: U.S. Geol. Survey Bull. 1000-E, p. 18i-223.

Keyes, Charles, 1913, History of geoglaphic development in Iowa: Iowa Geol. Survey Ann. Rept., v. 22, p. 15-155.

Ladd, H. S., 1929, The stratigraphy and paleontology of the Maquoketa shale of Iowa: Iowa Geol. Survey Ann. Rept., v. 34, p. 305-448.

Leonard, A. G., 1897, Lead and zinc deposits of Iowa: Iowa Geol. Survey Ann. Rept., v. 6, p. 11-66.

Lincoln, F. C., 1948, Dubuque lead-\%inc district, Iowa: U.S. Bur. Mines Rept. Inv. 4212 , p. 7 .

Martin, Lawrence, 1916, The physical geography of Wisconsin: Wisconsin Geol. and Nat. History Survey, Bull. 36, 549 p.

Norton, W. H., 1899, Geology of Scott County: Iowa Geol. Survey Ann. Rept., v. 9 , p. $391-519$.

Owen, D. D., 1840, Report of a geological exploration of part of Iowa, Wisconsin, and Illinois, 1839: U.S. Cong., 26th, 1st sess., Cong. Doc., House Ex. Doc. 239.

Pettijohn, F. J., 1949, Sedimentary rocks: New York, Harper \& Bros., 526 p.

Reynolds, R. R., 1958, Factors controlling the localization of ore deposits in the Shullsburg area, Wisconsin-Illinois zinc-lead district: Econ. Geology, v. 53, p. 141-163.

Ross, C. S., 1946, Sauconite-a clay mineral of the montmorillonite group: Am. Mineralogist, v. 31, no. 9, p. 411-424.

Sardeson, F. W., 1907, Galena series: Geol. Soc. America Bull., v. 1.8, p. 179-194.

Savage, T. E., 1906, Geology of Jackson County, Iowa: Iowa Geol. Survey Ann. Rept., v. 16, p. 567-642.

1909, The Ordovician and Silurian formations in Alexander County, Illinois: Am. Jour. Science, 4th ser., v. 28, p. 509-519.

1914, Relations of the Alexandrian series in Illinois and Missouri to the Silurian section of Iowa: Am. Jour. Sci., 4th ser., v. 38, p. 28-37.

- 1916, Alexandrian rocks of northeastern Illinois and eastern Wisconsin: Geol. Soc. America Bull., v. 27, p. 305-324.

1926, Silurian rocks of Illinois: Geol. Soc. America Bull., v. 37, p. 513534.

Savage, 'T. E., and Ross, C. S., 1916, The age of the iron ore in eastern Wisconsin: Am. Jour. Sci., 4th ser., v. 41, p. 187-193.

Scobey, E. H., 1938, The Alexandrian series in lowa: Jour. Geology, v. 46, p. $207-217$.

Shaw, E. S., and Trowbridge, A. C., 1916, Galena-Elizabeth quadrangles: U.S. Geol. Survey Geol. Atlas, Folio 200.

Sutton, A.H., 1935, Stratigraphy of the Silurian system of the upper Mississippi Valley: Kansas Geol. Soc. Gujdebook 9th Ann. Field Conf., p. 268-280. 
Trowbridge, A. C., 1921, The erosional history of the Driftless area: Iowa Univ. Studies Nat. Fistory, v. 9, no. 3, 127 p., 35 figs.

1954, Mississippi River and Gulf. Coast termaces and sediments as related to P'leistocene history-A problem: Geol. Soc. America Bull., v. 65, p. 793812.

Ulrich, E. O., 1924, Notes on new names in table of formations and on physical evidence of breaks between Paleozoic systems in Wisconsin: Wisconsin Acad. Sci., Arts, Letters Trans., v. 21, p. 71-107.

Weiss, M. P., 1955, Some Ordovician brachiopods from Minnesota and their stratigraphic relations: Jour. Paleontology, p. 759-774.

White, C. A., 1870, Report on the geological survey of the State of Jowa: Towa Geol. Survey Ann. Rept., v. 1.

Whitney, J. D., 1858, Chemistry and economical geology fof Towa], in Hall, James, and Whitney, J. D., Report on the geological survey of the State of lowa: Iowa Geol. Survey Ann. Rept., v. 1, p. 324-472.

Willman, H. B., and Reynolds, R. R., 1947, Geological structure of the zinc-lend district of northwestern Illinois: Illinois Geol. Survey Rept. Inv. 124, p. 15.

Workman, L. W., 1950, The Neda formation in northeastern Illinois: Illinois Acad. Sci. T.rans., v. 43, p. 176-182. 


\section{RECORDS OF DRILL HOLES}

The following records of drill holes are from drilling done in 195 for the U.S. Geological Survey. These holes in and near the Dubuque South quadrangle were drilled to obtain subsurface information about the stratigraphy and structure of rocks of Silurian and Ordovician age. Some conclusions reached as a result of this drilling are listed on page 23 of this report.

Three holes-U.S.G.S. 1, 2, and 3-were drilled to test structures mapped in 1953-54 (Brown and others, 1957) for lead- and zincmineralized rock in the lower part of the Galena dolomite and the Decorah formation. U.S.G.S. drillhole 3 was discontinued before reaching this zone because broken ground made drilling extremely difficult.

The records are arranged numerically, and the location of holes is shown on figure 18.

\section{USGS 1}

Location. $1,900 \mathrm{ft}$ east and $2,100 \mathrm{ft}$ south of northwest corner sec. 27, T. 89 N., R. 2 E., Iowa.

Driller. A. Scott.

Date. Nov. 22 to $25,1955$.

Collar altitude. $839.7 \mathrm{ft}$.

Total depth. $202 \mathrm{ft}$.

Depth to water. $7 \mathrm{ft}$.

Sample study and logging. J. W. Whitlow and C. E. Brown.

Surficial:

Soil and alluvium

$0-12$

Galena dolomite:

Noncherty unit:

Dolomite, grayish-orange, fine-grained, crystalline

Cherty unit:

Dolomite, pale-grayish-orange, medium-grained, crystalline, calcitic; as much as 20 percent tan and gray mottled chert...

Dolomite, as above; as much as 50 percent gray and brown

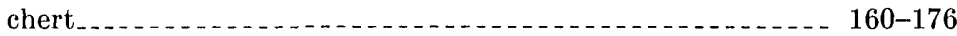

Decorah formation:

Ion dolomite member:

Dolomite, light-gray, argillaceous, medium-grained, calcitic_- 176-188

Limestone, gray, dolomitic, medium-grained; bluish-gray shale fragments; rounded quartz grains.................. 188-193

Guttenberg limestone member:

Limestone, pale-brown, fine-grained, siliceous, dolomitic; trace of brown chert; abundant chocolate-brown shale _. . . . . . _.. 193-201 Spechts Ferry shale member:

Limestone, dense, gray, argillaceous _... 201-202 
Estimated metallic content in percent

\begin{tabular}{|c|c|c|c|}
\hline Depth (feet) & $\underset{\text { sphalerite) }}{\text { Zinc (in }}$ & $\begin{array}{l}\text { Lead (in } \\
\text { galena) }\end{array}$ & $\begin{array}{c}\text { Iron (in } \\
\text { iron sulfide) }\end{array}$ \\
\hline $175-180$ & Trace & Trace & 1 \\
\hline $180-190$ & Trace & & 1. \\
\hline $1.90-200$ & Trace & Trace & $1-2$ \\
\hline
\end{tabular}

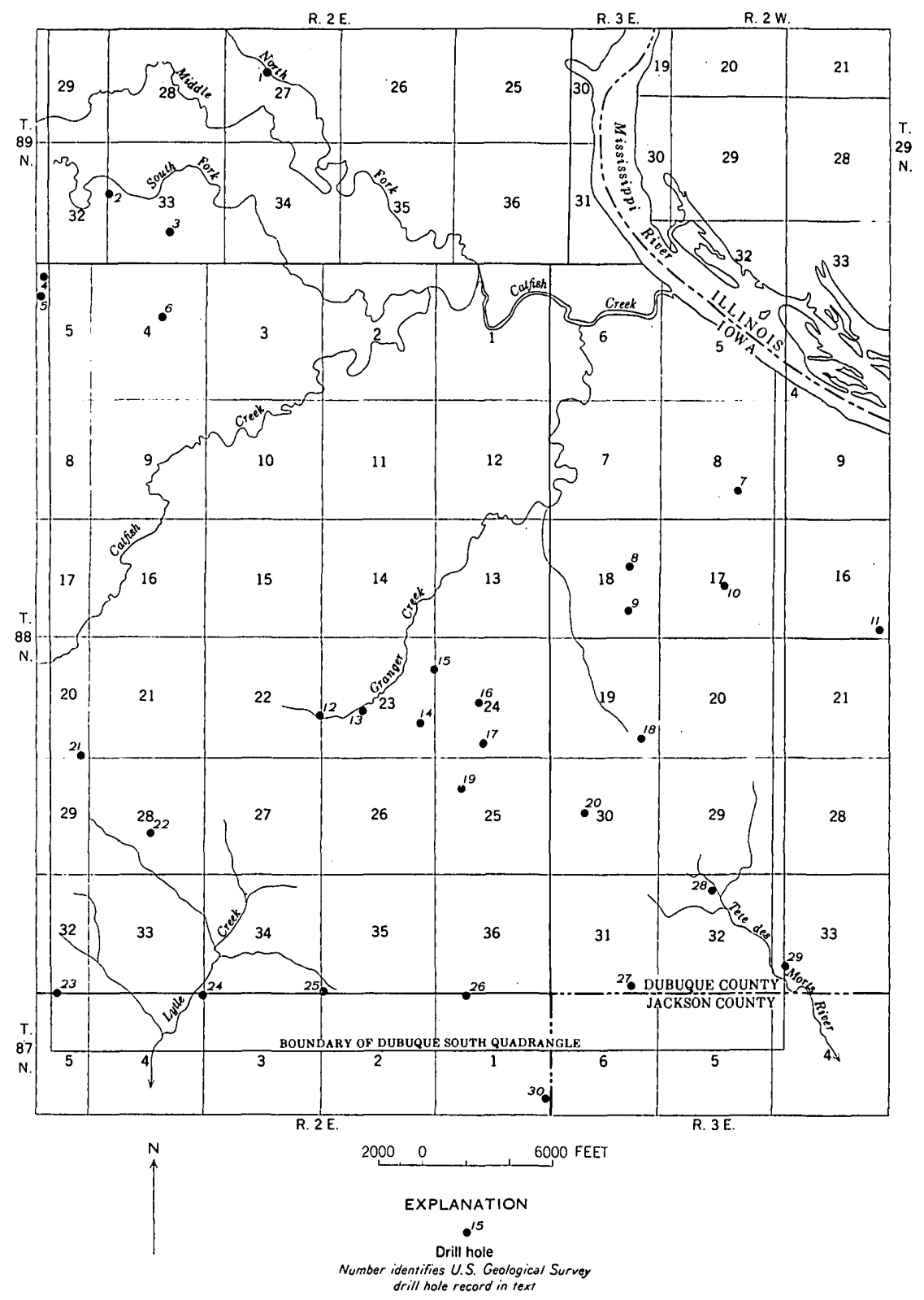

Figura 18.- Index map showing location of holes drilled in and near the Dubuque South quadrangle, Iowa-Illinols, for the Geological Survey in $\mathbf{1 9 5 5 .}$ 


\section{USGS 2}

Location. $470 \mathrm{ft}$ north and $100 \mathrm{ft}$ east of the southwest corner of the $\mathrm{NW} 1 / 4$ sec. 33, T. 89 N., R. 2 E., Iowa.

Driller. L. Schloeman.

Date. Nov. 19 to $23,1955$.

Collar altitude. $755.4 \mathrm{ft}$.

Total depth. $247 \mathrm{ft}$.

Depth to water. $60 \mathrm{ft}$.

Sample study and logging. C. E. Brown and J. W. Whitlow.

Surficial:

Soil, dark-brown $\ldots \ldots \ldots$

Galena dolomite:

Noncherty unit:

Dolomite; grayish-orange, fine-grained, argillaceous _..._.... 4-45

Dolomite, tan to light-gray, dense, fine-grained........... 45-94

Cherty unit:

Dolomite, gray to pale-brown, fine-grained, porous; as much as 10 percent mottled gray chert................ 94-130

Dolomite, hard, light-olive gray, fine-grained; trace of chert - $_{\text {- 130-145 }}$

Dolomite, porous, pale-yellowish-brown; as much as 10 percent

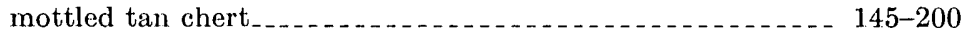

Limestone, dolomitic, yellowish brown . . . . . . . . . . . . . 200-210

Decorah formation:

Ion dolomite member:

Limestone, mottled, light-gray and tan, granular, argillaceous _ 210-222

Limestone, gray, argillaceous; blue-green shale partings _._._. 222-229

Guttenberg limestone member:

Limestone, yellowish-brown, fine-grained, fossiliferous; choco-

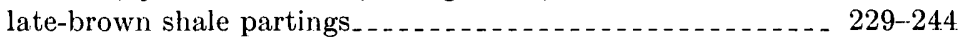

Spechts Ferry shale member:

Shale, green, fossiliferous; greenish-gray fine-grained limestone_ 244-247

Estimated metallic content, $i m$ percent

[Zinc and iron content from 135-140-ft depth assayed by W. R. Loy, Wis. Inst. Tech.]

$\begin{array}{ccc}\text { Depth (feet) } & \begin{array}{c}\text { Zinc } \\ \text { (in sphalerite) }\end{array} & \text { (in iron sulfide) } \\ 135-140 & 1.75 & 1.90 \\ 140-155 & \text { Trace } & \text { Trace } \\ 205-215 & -1-1-1- & \text { Trace }\end{array}$

USGS 3

Location. $1,500 \mathrm{ft}$ north and $2,660 \mathrm{ft}$ west of southeast corner sec. $33, \mathrm{~T} .89 \mathrm{~N}$., R. 2 E., Iowa.

Driller. A. Scott.

Date. Nov. 26 to Dec. 1, 1955.

Collar altitude. $821.8 \mathrm{ft}$.

Total depth. $231 \mathrm{ft}$. (Drilling discontinued because of extremely cavernous rock.)

Depth to water. $135 \mathrm{ft}$.

Sample study and logging. J. W. Whitlow. 
Surficial:

Soil, loess, light-brown _........

Glacial till; light-brown clay, silt, and quartz sand; chert fragments. 1.7-42

Glacial till; as above but light-gray and limy ................ 42-58

Maquoketa shale:

Brown shaly unit:

Shale, moderately hard, brown; phosphatic depauperate fossils

in lower $2 \mathrm{ft}$

Galena dolomite:

Noncherty unit:

Dolomite, yellowish-gray, fine-grained, argillaceous .

$66-100$

Dolomite, pale-grayish-orange, fine-grained, crystalline

Cherty unit:

Dolomite, light-brown, porous, medium-grained; 5 to 35 percent gray to brown mottled chert; calcite is common.

\section{Estimated metallic content}

\begin{tabular}{|c|c|c|}
\hline Depth (feet) & $\begin{array}{c}\text { Zinc } \\
\text { (in sphalerite) }\end{array}$ & $\begin{array}{c}\text { Iron } \\
\text { (in iron sulffide) }\end{array}$ \\
\hline $65-90$ & Trace & Trace \\
\hline $90-1.00$ & & Trace \\
\hline $1.00-1.10$ & Trace & Trace \\
\hline $130-135$ & - & Trace \\
\hline $135-230$ & - & Trace \\
\hline
\end{tabular}

USGS 4

Location. $2,110 \mathrm{ft}$ west and $560 \mathrm{ft}$ south of the northeast corner sec. 5, T. $88 \mathrm{~N}$., R. 2 E., Iowa.

Driller. L. Schloeman.

Date. Nov. 24 to $25,1955$.

Collar altitude. $877.8 \mathrm{ft}$.

Total depth. $116 \mathrm{ft}$.

Depth to water. No water.

Sample study and logging. C. E. Brown and J. W. Whitlow.

Surficial:

Depth

(feet)

Soil, loess, glacial till

Clay, yellowish-green (from Brainard member of Maquoketa shale); mixed with numerous fragments of chert (from rocks of Silurian age); probably a soliftuction layer.

Maquoketa shale:

Brown shaly unit:

Shale, soft, light-gray

Shale, soft, brown, dolomitic, silty

Shale, hard, dark-brown .................................

Shale, dark-brown, dolomitic, silty, phosphatic depauperate fossils in lower $2 \mathrm{ft}$

Galena dolomite:

Noncherty unit:

Dolomite, gray, dense, argillaceous

Estimated metallic content, in percent

$\begin{array}{ccc}\begin{array}{c}\text { Depth } \\ \text { (feet) }\end{array} & \begin{array}{c}\text { Iron (in iron } \\ \text { sulfide) }\end{array} & \begin{array}{c}\text { Barium (in } \\ \text { barite) }\end{array} \\ 113-116 & 2 & 11 / 2\end{array}$


USGS 5

Location. $1,400 \mathrm{ft}$ south and $2,280 \mathrm{ft}$ west of the northeast corner sec. $5, \mathrm{~T} .88 \mathrm{~N}$., R. 2 E., Iowa.

Driller. A. Scott.

Date. Dec. 2 to $3,1955$.

Collar altitude. $863.7 \mathrm{ft}$.

Total depth. $101 \mathrm{ft}$.

Depth to water. No water.

Sample study and logging. J. W. Whitlow.

Surficial:

Soil, light-brown, silty

Depth

(feet)

Clay, yellowish to grayish-brown, silty and limy; fragments of chert and quartz grains

Maquoketa shale:

Brainard member:

Shale, soft, yellowish-green and gray

Shale, soft, light-gray; 5 percent gray silty dolomite

Shale, as above

Brown shaly unit:

Shale, hard, brown; brown argillaceous dolomite

Shale, brown; phosphatic depauperate fossils in lower $2 \mathrm{ft} \ldots \ldots$. . 93-98

Galena dolomite:

Noncherty unit:

Dolomite, light-brown to gray, argillaceous

98-101

\section{USGS 6}

Location. $2,280 \mathrm{ft}$ south and $2,000 \mathrm{ft}$ west of the northeast corner sec. 4, T. $88 \mathrm{~N}$., R. 2 E., Iowa.

Driller. L. Schloeman.

Date. Nov. 25 to $26,1955$.

Collar altitude. $864.5 \mathrm{ft}$.

Total depth. $93 \mathrm{ft}$.

Depth to water. $45 \mathrm{ft}$.

Sample study and logging. J. W. Whitlow.

\section{Surficial:}

Soil, loess, glacial drift.

Maquoketa shale:

Brainard member:

Shale, soft, light-gray and light-brown, silty

Brown shaly unit:

Dolomite, argillaceous, medium-gray; light-brown hard shale_._ 39-47

Shale, soft, gray _...

Shale, hard, dark-brown; some gray soft shale; dolomitic in lower $5 \mathrm{ft}$; phosphatic depauperate fossils in lower $2 \mathrm{ft}_{\text {. . . . }} 58-91$

Galena dolomite:

Noncherty unit:

Dolomite, gray, fine-grained 


\section{USGS 7}

Location. $1,620 \mathrm{ft}$ west and $1,390 \mathrm{ft}$ north of the southeast corner sec. $8, \mathrm{~T}$. 88 N., R. 3 E., Iowa.

Driller. L. Schloeman.

Date. Nov. 9 to 11,1955 .

Collar altitude. $862.8 \mathrm{ft}$.

Total depth. $220 \mathrm{ft}$.

Depth to water. $175 \mathrm{ft}$.

Sample study and logging. C. E. Brown and J. W. Whitlow.

Surficial:

Depth

$($ feet $)$

Soil, loess, chert fragments .

Maquoketa shale:

Brainard member:

Shale, soft, light-green and light-gray _............... 17-46

Brown shaly unit:

Shale, hard, dolomitic, brown ........... 46-50

Shale, soft, brownish-gray _. _............. 50-85

Shale, hard, brownish-black; phosphatic depauperate fossils in lower $2 \mathrm{ft}$

Galena dolomite:

Noncherty unit:

Dolomite, grayish-yellow, limonite-stained, argillaceous ____. 94-114

Cave _...

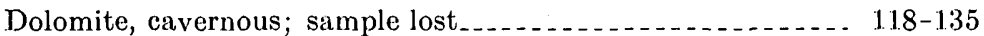

Dolomite, limonite-stained; disintegrated to dolomite sand _.. - 135-153

Dolomite, light-brown and yellowish-gray, fine-grained . . . . . 153-210)

Cherty unit:

Dolomite, yellowish-gray, hard, medium-grained; dark-gray chert common _............... 210-220

Estimated metallic content, in percent

$\begin{array}{cc}\begin{array}{c}\text { Depth } \\ \text { (feet) }\end{array} & \text { Iron } \\ 210-220 & \text { (in iron sulfide) }\end{array}$

\section{USGS 8}

Location. $1,320 \mathrm{ft}$ west and $2,035 \mathrm{ft}$ south of the northeast corner sec. $18, \mathrm{~T}$. 88 N., R. 3 E., Iowa.

Driller. L. Schloeman.

Date. Nov, 5 to $8,1955$.

Collar altitude. $819.5 \mathrm{ft}$.

Total depth. $160 \mathrm{ft}$.

Depth to water. $110 \mathrm{ft}$.

Sample study and logging. C. E. Brown and J. W. Whitlow.

Surficial: Depth

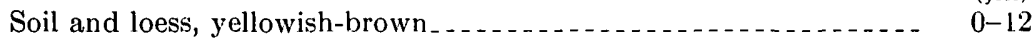

Clay, yellow-green and brown; many weathered chert and dolomite

fragments........................................ 122 
Maquoketa shale:

Brown shaly unit:

Shale, dark-brown, moderately hard; phosphatic depauperate

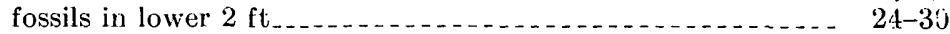

Galena dolomite:

Noncherty unit:

Dolomite, grayish-orange, argillaceous, fine-grained _. _. _... 30-60

Dolomite, grayish-yellow, fine-crystalline _.............. 60-148

Cherty unit:

Dolomite, grayish-orange, medium-grained, crystaliine; tan mottled chert common.

\section{USGS 9}

Location. $1,370 \mathrm{ft}$ west and $1,365 \mathrm{ft}$ north of southeast corner sec. 18, T. $88 \mathrm{~N}$., R. 3 E., Iowa.

Driller. L. Schloeman.

Date. Nov. 3 to 5,1955 .

Collar altitude. $858.4 \mathrm{ft}$.

Total depth. $202 \mathrm{ft}$.

Depth to water. $140 \mathrm{ft}$.

Sample study and logging. J. W. Whitlow.

Surficial:

Soil and loess, light-brown _................. $0-16$

Maquoketa shale:

Brainard member:

Shale, soft, silty, brownish-gray

Brown shaly unit:

Dolomite, grayish-brown, fine-grained, argillaceous

Shale, soft, grayish-brown, silty _. _. _ _ _ _ _ _ _ _ _ _ $32-60$

Shale, hard, brownish-black: phosphatic depauperate fossils in lower $2 \mathrm{ft}$

Galena dolomite:

Noncherty unit:

Dolomite, grayish-orange, f ne-grained, argillaceous _. _..... 71-85

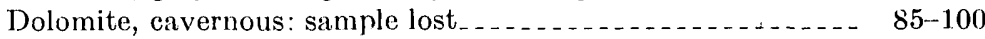

Dolomite, grayish-yellow, friable; unctuous brown clay . . . . . 100-135

Dolomite, grayish-orange, porous, medium-grained _....... 135-185

Cherty unit:

Dolomite, light-brown, medium-grained, crystalline; as much as 10 percent light-gray to yellowish-brown chert.

$185-202$

\section{USGS 10}

Location. $2,350 \mathrm{ft}$ north and $2,250 \mathrm{ft}$ west of southeast corner sec. 17, T. $88 \mathrm{~N}$., R. 3 E., Iowa.

Driller. A. Judd.

Date. Nov. 1 to 3,1955 .

Collar altitude. $953.7 \mathrm{ft}$.

Total depth. $175 \mathrm{ft}$.

Depth to water. No water.

Sample study and logging. C. E. Brown and J. W. Whitlow. 
Surficial:

Clay, brown and grayish-green; common weathered dolomite and

chert fragments . . . . . . . . . . . . . . . . . . . . . . . . .

Maquoketa shale:

Brainard member:

Shale, soft, light-gray and greenish-gray, silty; dolomitic in lower $10 \mathrm{ft}$

Brown shaly unit:

Dolomite, olive-gray, fine-grained, argillaceous; soft silty shale as above

Shale, brownish-gray, silty, moderately hard, dolomitic

Shale, hard, brownish-black, silty; phosphatic depauperate fossils in lower $2 \mathrm{ft}$

Galena dolomite:

Noncherty unit:

Dolomite, pale-yellowish-orange, fine-grained

\section{USGS 11}

Location. $480 \mathrm{ft}$ west and $350 \mathrm{ft}$ north of the southeast corner sec. 16, T. 88 N., R. 3 E., Iowa.

Driller. A. Scott.

Date. Nov. 12 to $18,1955$.

Collar altitude. $775.8 \mathrm{ft}$.

Total depth. $278 \mathrm{ft}$.

Depth to water. $60 \mathrm{ft}$.

Sample study and logging. C. E. Brown and J. W. Whitlow.

Surficial:

Soil, dark-brown; yellowish-green with chert fragments..........

Galena dolomite:

Noncherty unit:

Dolomite, grayish-yellow, fine-grained, argillaceous . . . . ......

Dolomite, grayish-orange and light-gray, medium-grained, crystalline

Cherty unit:

Dolomite, grayish-orange and light-gray; tan and gray mottled chert, common

Limestone, light-olive-gray, fine-grained; disseminated dolomite rhombs; yellowish-brown, calcitic, crystalline dolomite; light-gray mottled chert, common . _.............. 190-226

Decorah formation:

Ion dolomite member:

Limestone, light-olive-gray, argillaceous, medium-grained, crystalline; dark-gray specks, common...

Limestone, olive-gray, medium-grained, argillaceous; green shale partings.

Guttenberg limestone member:

Limestone, pale-brown, fine-grained, fossiliferous; brown shale partings

Spechts Ferry shale member:

Shale, grayish-green, soft; dense, gray limestone 
Platteville formation:

Quimbys Mill member:

Limestone, pale-brown, sugary-textured, fine-grained; chocolate

brown, black-specked shale............

Depth
$($ feet $)$

270-274

McGregor limestone member:

Limestone, light-olive-gray, fine-grained, fossiliferous.

$274-278$

\section{USGS 12}

Location. $1,920 \mathrm{ft}$ north and $4.0 \mathrm{ft}$ east of the southwest corner sec. 23 , T. $88 \mathrm{~N}$., R. 2 E., Iowa.

Driller. L. Schloeman.

Date. Nov. 18, 1955.

Collar altitude. $803 \mathrm{ft}$.

Total depth. $80 \mathrm{ft}$.

Depth to water. $10 \mathrm{ft}$.

Sample study and logging. C. E. Brown and J. W. Whitlow.

Surficial:

Soil and alluvium ................ 0-20

Maquoketa shale:

Brainard member:

Shale, soft, gray

Brown shaly unit:

Dolomite, hard, brown, argillaceous

Shale, soft, gray

Shale, moderately hard, brown; phosphatic, depauperate fossils in lower $2 \mathrm{ft}$

Galena dolomite:

Noncherty unit:

Dolomite, gray, fine-grained, argillaceous

Estimated metallic content, in percent

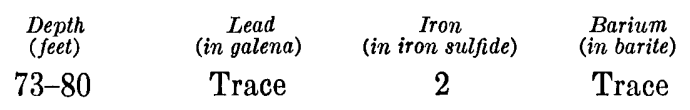

USGS 13

Location. $2,020 \mathrm{ft}$ east and 2,140 ft north of southwest corner sec. $23, \mathrm{~T} .88 \mathrm{~N}$, R. 2 E., Iowa.

Driller. L. Schloeman.

Date. Nov. 15 to $17,1955$.

Collar altitude. $\quad 770.5 \mathrm{ft}$.

Total depth. $160 \mathrm{ft}$.

Depth to water. $4 \mathrm{ft}$.

Sample study and logging. C. E. Brown and J. W. Whitlow.

Surficial:

Soil and alluvium

Maquoketa shale:

Brown shaly unit:

Shale, soft, bluish-gray

Shale, dark-brown; phosphatic depauperate fossils in lower $2 \mathrm{ft}$ 
Galena dolomite:

Noncherty unit:

Dolomite, gray, dense, argillaceous_............. 35-60

Dolomite, light-gray to tan, fine-grained............... 60-149

Cherty unit:

Dolomite, light-brown; brownish-yellow chert

Estimated metallic content, in percent

$\begin{array}{cccc}\begin{array}{c}\text { Depth } \\ \text { (jeet) }\end{array} & \begin{array}{c}\text { Zinc } \\ \text { (in sphalerite) }\end{array} & \begin{array}{c}\text { Lead } \\ \text { (in jalena) }\end{array} & \begin{array}{c}\text { Iron } \\ \text { (in iron sulfide) }\end{array} \\ 35-40 & <1 & \text { Trace } & 1-2 \\ 40-60 & \text { Trace } & -\ldots-\ldots .- & \text { Trace } \\ 140-145 & \text { Trace } & -\ldots-\ldots . . & \text { Trace }\end{array}$

\section{USGS 14}

Location. $1,590 \mathrm{ft}$ north and $650 \mathrm{ft}$ west of southeast corner sec. 23, T. $88 \mathrm{~N}$, R. 2 E., Iowa.

Driller. A. Scott.

Date. Nov. 18 to $22,1955$.

Collar altitude. $965 \mathrm{ft}$.

Total depth. $250 \mathrm{ft}$.

Depth to water. $75 \mathrm{ft}$.

Sample study andlogging. C. E. Brown and J. W. Whitlow.

Edgewood dolomite:

Tete des Morts member:

Dolomite, pale-grayish-

glauconite common . . .

Mosalem member:

Dolomite, pale-grayish-orange to pale-brown, dense, argillaceous; as much as 10 percent light-brown chert........... 20-51

Maquoketa shale:

Brainard member:

Shale, soft, grayish-green and grayish-blue; hematite-stained $65-78 \mathrm{ft}$

Brown shaly unit:

Dolomite, grayish-brown, argillaceous; dark-brown silty shale _ 197-209

Shale, soft, grayish-brown _. _. _ _. 209-228

Shale, moderately hard, brownish-black, silty; phosphatic depauperate fossils in lower $2 \mathrm{ft} \ldots \ldots$. . . . . . . . . . . . 228-240

Galena dolomite:

Noncherty unit:

Dolomite, gray, argillaceous

Estimated metallic content, in percent

$\begin{array}{ccccc}\begin{array}{c}\text { Depth } \\ \text { (feet) }\end{array} & \begin{array}{c}\text { Zinc } \\ \text { (in sphalerite) }\end{array} & \begin{array}{c}\text { Lead } \\ \text { (in galena) }\end{array} & \begin{array}{c}\text { Iron } \\ \text { (in iron sulfide) }\end{array} & \begin{array}{c}\text { Barium } \\ \text { (in barite) }\end{array} \\ 195-205 & ----- & \text { Trace } & 1 & -1-.- \\ 240-250 & \text { Trace } & \text { Trace } & 3 & \text { Trace }\end{array}$




\section{USGS 15}

Location. 1,360 ft south and $50 \mathrm{ft}$ west of northeast corner sec. $23, \mathrm{~T} .88 \mathrm{~N}$., R. 2 E., Iowa.

Driller. L. Schloeman.

Date. Nov. 12 to $15,1955$.

Collar altitude. $755 \mathrm{ft}$.

Total depth. $140 \mathrm{ft}$.

Depth to water. $25 \mathrm{ft}$.

Sample study and logging. C. E. Brown and J. W. Whitlow.

Surficial:

Soil and alluvium

Galena dolomite:

Noncherty unit:

Dolomite, pale-grayish-orange and light-gray, argillaceous,

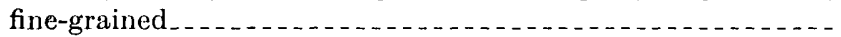

Dolomite, grayish-orange and gray, hard, fine-grained...... $35-124$ Cherty unit:

Dolomite, yellowish-brown, fine-grained; light-gray mottled chert; cavernous rock 130 to $135 \mathrm{ft} \ldots \ldots \ldots$. $124-140$

\section{USGS 16}

Location. $\quad 2,450 \mathrm{ft}$ north and $2,040 \mathrm{ft}$ east of the southwest corner sec. 24, T. 88 N., R. 2 E., Iowa.

Driller. A: Scott.

Date. Nov. 7 to $9,1955$.

Collar altitude. $796 \mathrm{ft}$.

Total depth. $176 \mathrm{ft}$.

Depth to water. $80 \mathrm{ft}$.

Sample study and logging. C. E. Brown and J. W. Whitlow.

Surficial:

Clay mixed with weathered chert and dolomite

Maquoketa shale:

Brown shaly unit:

Shale, bluish-gray and brown, soft, silty

Shale, hard, brown, silty; phosphatic depauperate fossiis in lower $2 \mathrm{ft}$

Galena dolomite:

Noncherty unit:

Dolomite, yellowish-gray, medium-grained, argillaceous.......

Dolomite, gray to grayish-orange, medium-grained, crystalline.

Dolomite, tan, medium-grained, crystalline; common mottled chert.

Estimated metallic content, in percent

[Iron content from 50-55-ft depth assayed by W. R. Loy, Wis. Inst. Tech.]

\begin{tabular}{|c|c|c|c|c|}
\hline Depth (feet) & $\begin{array}{c}\text { Zinc (in } \\
\text { sphalerite) }\end{array}$ & $\begin{array}{l}\text { Iead (in } \\
\text { galena) }\end{array}$ & $\begin{array}{l}\text { Iron (in iron } \\
\text { sulfide) }\end{array}$ & $\begin{array}{c}\text { Barium (in } \\
\text { barite) }\end{array}$ \\
\hline $40-45$ & $\ldots$ & $\ldots$ & $3-4$ & \\
\hline $45-50$ & Trace & Trace & 10 & \\
\hline $50-55$ & Trace & Trace & 13. 4 & \\
\hline $55-60$ & Trace & Trace & 4 & $\operatorname{Tr}$ \\
\hline $60-155$ & $\ldots$ & $\cdots$ & $>2$ & \\
\hline
\end{tabular}




\section{USGS 17}

Location. $\quad 2,240 \mathrm{ft}$ east and $585 \mathrm{ft}$ north of southwest corner of sec. $24, \mathrm{~T} .88 \mathrm{~N}$., R. 2 E., Iowa.

Driller. A. Scott.

Date. Nov. 9 to $10,1955$.

Collar altitude. $838 \mathrm{ft}$.

Total depth. $104 \mathrm{ft}$.

Depth to water. $35 \mathrm{ft}$.

Sample study and logging. C. E. Brown and J. W. Whitlow.

Surficial:

Clay, yellowish-green; weathered chert and dolomite fragments....

Maquoketa shale:

Brainard member:

Shale, soft, greenish-gray and light bluish gray

Brown shaly unit:

Dolomite, brownish-gray, argillaceous; brown and olive-gray shale.

Shale, soft, brownish-gray and olive-gray ................

Shale, brownish-black; phosphatic depauperate fossils in lower $2 \mathrm{ft}$

Galena dolomite:

Noncherty unit:

Dolomite, light-olive-gray, fine-grained, argillaceous

Estimated metallic content

$\begin{array}{ccc}\begin{array}{c}\text { Depth } \\ \text { (feet) }\end{array} & \begin{array}{c}\text { Zinc } \\ \text { (in sphalerite) }\end{array} & \begin{array}{c}\text { Iron } \\ \text { (in iron sulfide) }\end{array} \\ 95-104 & \text { Trace } & \text { Trace }\end{array}$

USGS 18

Location. $850 \mathrm{ft}$ north and $700 \mathrm{ft}$ west of southeast corner sec. 19, T. $88 \mathrm{~N}$, R. 3 E., Iowa.

Driller. A. Scott.

Date. Nov. 4 to 5,1955 .

Collar altitude. $960 \mathrm{ft}$.

Total depth. $212 \mathrm{ft}$.

Depth to water. $87 \mathrm{ft}$.

Sample study and logging. C. E. Brown and J. W. Whitlow.

Surficial:

Depth

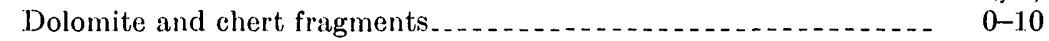

Edgewood dolomite:

Mosalem member:

Dolomite, grayish-orange, fine-grained, dense, silty; 8 to 15

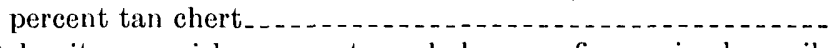

Dolomite, grayish-orange to pale-brown, fine-grained, argillaceous; trace of chert 35 to $45 \mathrm{ft}$

Dolomite, grayish-yellow, silty, black-specked; grayish-green shale partings 
Maquoketa shale:

Brainard member:

Shale, soft, greenish-gray and light-gray, silty

Shale, soft, gray, silty, dolomitic

Brown shaly unit:

Dolomite, brown, silty, argillaceous, medium-grained; soft gray shale

Shale, moderately hard, light-olive-gray, dolomitic .......... 173-202

Shale, moderately hard, brown; phosphatic depauperate fossils in lower $2 \mathrm{ft}$

Galena dolomite:

Noncherty unit:

Dolomite, light-gray, argillaceous, fine-grained

Estimated metallic content, in percent

$\begin{array}{lcc}\text { Depth (feet) } & \text { Zinc (in sphalerite) } & \text { Iron (in iron sulfide) } \\ 207-212 & \text { Trace } & 1\end{array}$

\section{USGS 19}

Location. $1,250 \mathrm{ft}$ east and 1,400 ft south of northwest corner sec. 25, T. 88 N., R. 2 E., Iowa.

Driller. A. Scott.

Date. Nov. 10 to $11,1955$.

Collar altitude. $876 \mathrm{ft}$.

Total depth. $146 \mathrm{ft}$.

Depth to water. $52 \mathrm{ft}$.

Sample study and logging. C. E. Brown and J. W. Whitlow.

$\begin{array}{ll}\text { Septh } & \text { Deet } \\ \text { Sucial: } & \text { (feet) }\end{array}$

Soil, and weathered chert and dolomite fragments . . . . . . . 0 0.12

Maquoketa shale:

Brainard member:

Shale, soft, yellowish-green and bluish-gray _...

Shale, soft, brownish-gray, silty _._._.

Brown shaly unit:

Shale, moderately hard, brown _...

Dolomite, brown, fine-grained, argillaceous .............. 100-107

Shale, soft, brown and gray _._.

Shale, moderately hard, dark-brown; phosphatic depauperate fossils in lower $2 \mathrm{ft}$

Galena dolomite:

Noncherty unit:

Dolomite, hard, gray, argillaceous 


\section{USGS 20}

Location. $850 \mathrm{ft}$ west and $75 \mathrm{ft}$ north of center sec. 30 , T. 88 N., R. 3 E., Iowa. Driller. L. Schloeman.

Date. Oct. 22 to $27,1955$.

Collar altitude. $1,053.3 \mathrm{ft}$.

Total depth. $340 \mathrm{ft}$.

Depth to water. $140 \mathrm{ft}$.

Sample study and logging. C. E. Brown and J. W. Whitlow.

Surficial:

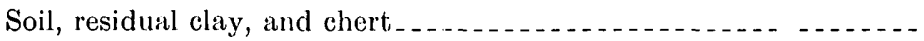

Hopkinton dolomite:

Dolomite, grayish-yellow, fine-grained, dense; as much as 1.5 percent white chert

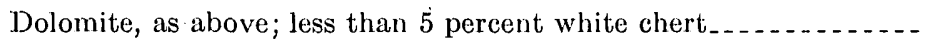

Kankakee formation:

Dolomite, grayish-yellow, dense, fine-grained; 20 to 70 percent white

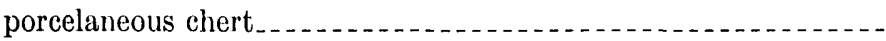

Dolomite, cream-colored with greenish cast, fine-grained, dense; as much as 10 percent white chert

Edgewood dolomite:

Tete des Morts member:

Dolomite, pale grayish orange, medium-grained; glauconite grains common; trace of light-gray chert

Mosalem member:

Dolomite, grayish-orange to light-gray; as much as 20 percent chert in lower $35 \mathrm{ft} \ldots \ldots \ldots$. . . 120

Dolomite, olive-gray, fine-grained, argillaceous, sugary, blackspecked . . 2. (170-180

Dolomite, as above; with some finely mottled gray and dark gray dolomite; pyrite is common . . . . . . . 180-193

Maquoketa shale:

Brainard member:

Shale, soft, greenish-gray and bluish-gray, silty

Shale, soft, brownish-gray, silty

Brown shaly unit:

Dolomite, brown, medium-grained, argillaceous; also hard

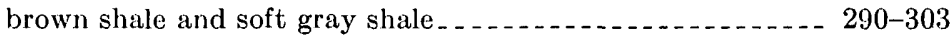

Shale, soft, grayish-brown, silty _. _ _ _ $303-323$

Shale, hard, brownish-black, black-specked; phosphatic depauperate fossils in lower $2 \mathrm{ft} \ldots \ldots \ldots$

Galena dolomite:

Noncherty unit:

Dolomite, light-gray to tan, fine-grained, argillaceous 


\section{USGS 21}

Location. $405 \mathrm{ft}$ west and $35 \mathrm{ft}$ north of southeast corner sec. 20 , T. 88 N., R. 2 E., Iowa.

Driller. A. Scott.

Date. Sept. 30 to Oct. 3, $1955(0-236 \mathrm{ft})$; Oct. 10 to $13,1955(236-461.5 \mathrm{ft})$.

Collar altitude. $1150 \mathrm{ft}$.

Total depth. $461.5 \mathrm{ft}$.

Depth to water. $160 \mathrm{ft}$.

Sample study and logging. C. E. Brown and J. W. Whitlow.

Surficial:

Soil, loess, and brown sandy glacial drift $\ldots \ldots \ldots$. 15

Hopkinton dolomite:

Dolomite, grayish-orange, porous, soft; trace of light-gray mottled

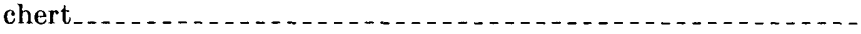

Dolomite, pale-yellowish-orange, fine-grained, dense; 3 to 20 percent white and yellowish-gray chert

Dolomite, pale-yellowish-brown, fine-grained, dense, argillaceous; chert is sparse.

Kankakee formation:

Dolomite, grayish-yellow, fine- to medium-grained; 25 to 50 percent white porcelaneous chert.

Dolomite, yellowish-gray, fine-grained, black-specked; trace of chert and pyrite

Tete des Morts member:

Dolomite, yellowish-gray, hard, dense; specked with glauconite _._.

Mosalem member:

Dolomite, yellowish-gray, medium-grained; about 20 percent gray speckled dolomite with phosphatic nodules and glau-

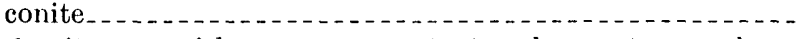

Dolomite, greenish-gray, sugary-textured, quartzose; abundant small phosphatic nodules and glauconite grains..... $190-195$

\section{Edgewood}

Maquoketa shale:
Neda member:

Neda member:
Shale, grayish-red, silty; common limonite oolites and phosphatic nodules.

Brainard member:

Shale, greenish-gray; and yellowish-gray argillaceous fossiliferous dolomite

Shale, soft, greenish-gray

Shale, moderately hard, bluish-green; and hard dark-yellowish-brown dolomite.

Shale, soft, grayish-green and grayish-blue _._._. _._. 265-405

Brown shaly unit:

Dolomite, hard, olive-gray, medium-grained; dark-greenish gray-dolomitic shale . . . . . . . . . . .

Shale, soft, grayish-brown

Shale, moderately hard, brownish-black; phosphatic depauperate fossils in lower $2 \mathrm{ft} \ldots \ldots$. . .

Galena dolomite:

Noncherty unit:

Dolomite, light-olive-gray, argillaceous, fine-grained 


\section{USGS 22}

Location. $800 \mathrm{ft}$ south and $50 \mathrm{ft}$ east of center, sec. 28 , T. 88 N., R. 2 E., Iowa. Driller. A. Scott.

Date. Oct. 4 to $8,1955$.

Collar altitude. $1076 \mathrm{ft}$.

Total depth. $391 \mathrm{ft}$.

Depth to water. $65 \mathrm{ft}$.

Sample study and logging. C. E. Brown and J. W. Whitlow.

Surficial:

Soil and loess, light-brown

Silt, sand, and pebbles (glacial drift) _....... 15-27

Hopkinton dolomite:

Dolomite, grayish-yellow, porous, fine-grained; 5 to 10 percent

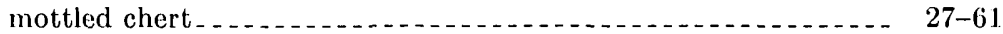

Dolomite, light-gray, fine-grained, crystalline, porous, noncherty - $\quad$ 61-84.

Kankakee formation:

Dolomite, gravish-yellow, fine-grained, 40 to 50 percent porcelaneous

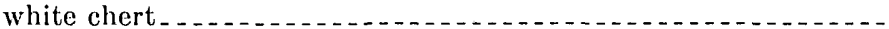

Edgewood dolomite:

Tete des Morts member:

Dolomite, light-gray with dark specks, fine-grained, dense, argillaceous; trace of glauconite and pyrite.

Mosalem member:

Dolomite, olive-gray, fine-grained; as much as 5 percent green shale partings; pyrite in lower $10 \mathrm{ft}$; phosphatic nodules in lower $5 \mathrm{ft}$

Maquoketa shale:

Brainard member:

Shale, soft, grayish-green; light-gray fossiliferous dolomite; trace of grayish-red shale and limonite concretions at top

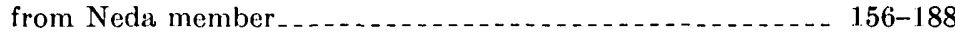

Dolomite, light-gray, fine-grained, argillaceous _. _. _. _.... 188-196

Shale, soft, grayish-blue and grayish-green ... _.......... 196-325

Brown shaly unit:

Shale, grayish-brown, moderately hard

Dolomite, grayish-brown, crystalline, fine-grained; shale as above . 2 2 - 335-345

Shale, soft, brown $\ldots$

Shale, moderately hard, brownish-black; phosphatic depauperate fossils in lower $2 \mathrm{ft}$

Galena dolomite:

Noncherty unit:

Dolomite, hard, gray, fine-grained

Estimated metallic content

$\begin{array}{ccc}\begin{array}{c}\text { Depth } \\ \text { (feet) }\end{array} & \begin{array}{c}\text { Zinc } \\ \text { (in sphalerite) }\end{array} & \begin{array}{c}\text { Iron } \\ \text { (in iron sulfide) }\end{array} \\ 365-370 & \text { Trace } & \\ 386-391 & \text { Trace } & \text { Trace }\end{array}$




\section{USGS 23}

Location. $14.60 \mathrm{ft}$ west, $15 \mathrm{ft}$ north of southeast corner sec. 32, T. $88 \mathrm{~N}$., R. 2 E., Iowa.

Driller. A. Scott.

Date. Sept. 27 to $30,1955$.

Collar altitude. $1078.0 \mathrm{ft}$.

Total depth. $275 \mathrm{ft}$.

Depth to water. $185 \mathrm{ft}$.

Sample study and logging. C. E. Brown and J. W. Whitlow.

Surficial:

Depth

(feet)

Soil, loess, glacial drift

Hopkinton dolomite:

Dolomite, grayish-orange, fine-grained _. . .

Dolomite, grayish-orange, fine-grained, porous; trace of mottled chert partly altered to white tripoli. .........................

Kankakee formation:

Dolomite, pale-grayish-orange, fine-grained, from 40 to 60 percent white porcelaneous chert

Dolomite, as above; 5 percent white chert; pale-green shale partings

$160-168$

Edgewood dolomite:

Tete des Morts member:

Dolomite, light-greenish-gray to yellowish-gray, fine-grained, porous; trace of glauconite and chert . . . . . . . . . . 168-190

Mosalem member:

Dolomite, grayish-yellow, fine-grained, crystalline

Dolomite, yellowish-gray and olive-gray, argillaceous, finegrained; yellowish brown shale partings and as much as 10 percent yellowish-gray earthy chert

Dolomite, hard, olive-gray, argillaceous, fine-grained, black specked; brownish-gray dolomitic shale in lower part. . _.. 235-260

Dolomite, greenish-gray, crystalline, mottled; abundant brown and grayish-green shale partings; phosphate nodules, glauconite, and pyrite are common

260-265

Maquoketa shale:

Brainard member:

Shale, soft, greenish-gray; plastic when wet

$265-275$

\section{USGS 24}

Location. $118 \mathrm{ft}$ west and $125 \mathrm{ft}$ south of northeast corner sec. $4, \mathrm{~T} .87 \mathrm{~N}$., R. 2 E., Iowa.

Driller. A. Scott.

Date. Sept. 21 to $26,1955$.

Collar altitude. $945 \mathrm{ft}$.

Total depth. $386 \mathrm{ft}$.

Depth to water. $12 \mathrm{ft}$.

Sample study and logging. J. W. Whitlow and C. E. Brown. 
Kankakee formation:

Dolomite, grayish-yellow to cream-colored, fine-grained, porous;

40 to 60 percent white and light-grav porcelaneous chert....... -

Dolomite, grayish-yellow to cream-colored, argillaceous, dense, fine-

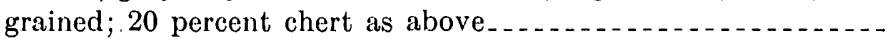

\section{Edgewood dolomite:}

Tete des Morts member:

Dolomite, pale-grayish-orange, medium-grained; glauconite and pyrite grains common; as much as 5 percent yellowishgray chert

Mosalem member:

Dolomite, light-gray, fine-grained, dark-specked, argillaceous; 3 to 5 percent" gray and wite chert..................

Dolomite, as above; chert as above; pale-brown shale partings common; trace of phosphatic black specks................

Dolomite, light-gray, shaly; as much as 20 percent brown-shale partings; trace of pyrite, sphalerite, and glauconite; 3 to 5 Maquoketa shale:

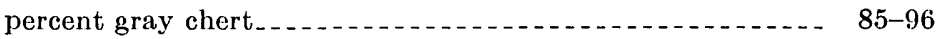

Brainard member:

Shale, soft, grayish-green and light-gray _._.

Shale, as above; medium-grained fossiliferous dolomite _._. - 105-115

Shale, as above......... 115-140

Shale, as above; trace of reddish-brown dolomite......... 140-155

Shale, soft, light-grayish-blue and light-gray _... _. . _... 155-204.

Shale, soft, light-brownish-gray _.._._.

Brown shaly unit:

Dolomite, brown, medium-grained, argillaceous........... 220-227

Shale, brown, silty; phosphatic depauperate fossils in lower $2 \mathrm{ft}$; pyrite common ............ 227-261

Galena dolomite:

Noncherty unit:



Dolomite, grayish-orange, hard, fine-grained _._. $\ldots \ldots \ldots$ 295-370

Cherty unit:

Dolomite, as above; mottled drab chert. $\ldots . .370-386$

\section{USGS 25}

Location. $64 \mathrm{ft}$ east and $19 \mathrm{ft}$ north of the southwest corner sec. 35, T. $88 \mathrm{~N}$., R. 2 E., Iowa.

Driller. A. Scott.

Date. Oct. 13 to $18,1955$.

Collar altitude. $1,043 \mathrm{ft}$.

Total depth. $363 \mathrm{ft}$.

Depth to water. $40 \mathrm{ft}$.

Sample study and logging. C. E. Brown and J. W. Whitlow. 
Hopkinton dolomite:

Dolomite, grayish-yellow to yellowish-gray, fine- to mediumgrained, porous; as much as 2 percent white to yellowish-gray chert

Kankakee formation:

Dolomite, yellowish-gray, dense, fine-grained; 10 to 60 percent white white porcelaneous chert; sparse green shale partings lower $5 \mathrm{ft}$. Edgewood dolomite:

Tete des Morts member:

Dolomite, yellowish-gray, argillaceous; trace of glauconite and light-gray chert

Mosalem member:

Dolomite, light-olive-gray, argillaceous, black-specked; as much as 5 percent light-gray chert....................

Dolomite, olive-gray, argillaceous, fine-grained; as much as 10 percent yellowish-gray chert; pale-brown shale partings more a bundant in lower part.

Dolomite, olive-gray, crystalline, porous, dark-specked, argillaceous; glauconite, phosphatic nodules and pyrite are

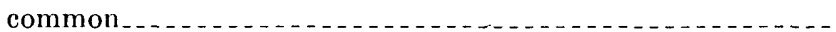

Maquoketa shale:

Brainard member:

Shale, soft, greenish-gray and bluish-gray; plastic when wet.-- 208-285

Shale, as above; 10 to 30 percent brownish-gray soft shale _. _ _ 285-315

Brown shaly unit:

Dolomite, grayish-brown medium-grained, silty _._. _. _ _ 315-325

Shale, soft, light grayish brown

Shale, brownish black, hard, silty, black specked; phosphatic

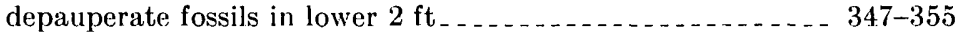

Calena dolomite:

Noncherty unit:

Dolomite, yellowish-gray, fine-grained, argillaceous

\section{USGS 26}

Location. $1,400 \mathrm{ft}$ east and $25 \mathrm{ft}$ south of the northwest corner sec. $1, \mathrm{~T} .87 \mathrm{~N}$., R. 2 E., Iowa.

Driller. A. Scott and A. Judd.

Date. Oct. 19 to $26,1955$.

Collar altitude. $1,093.8 \mathrm{ft}$.

Total depth. $401 \mathrm{ft}$.

Depth to water. $50 \mathrm{ft}$.

Sample study and logging. J. W. Whitlow and C. E. Brown.

Surficial:

Depth

(feet)

Soil, glacial till, residual chert ...

Hopkinton dolomite:

Dolomite, grayish-yellow, porous, fine-grained, crystalline; trace of white and yellowish-gray chert

Dolomite, yellowish-gray, fine- to medium-grained; common chert as above; 50 percent chert 65 to $70 \mathrm{ft}$

Dolomite, as above; noncherty ............................... 
Kankakee formation:

Dolomite, light-grayish-orange, porous, fine-grained; 50 to 70 Dept percent white porcelaneous chert . . 2. 2. 110-150

Dolomite, yellowish-gray and pale-greenish-gray, fine-grained; 5 percent white chert .

Edgewood dolomite:

Tete des Morts member:

Dolomite, yellowish-gray, fine-grained, porous; glauconite grains are common; trace of chert.................. 160-180

Mosalem member:

Dolomite, yellowish-gray to light-olive-gray, fine-grained, argillaceous; light-brown shale partings increase in abundance downward; as much as 2 percent light-gray chert.........

Dolomite, olive-gray, black-specked, argillaceous; light-brown

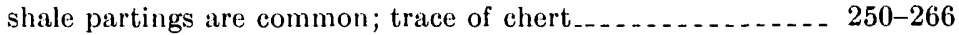

Dolomite, olive-gray, porous, coarse crystalline; bluish-green shale in lower $5 \mathrm{ft}$; phosphatic nodules and pyrite is common, 266-276 Maquoketa shale:

Brainard member:

Shale, soft, greenish-gray and bluish-gray; plastic if wet

Brown shaly unit:

Dolomite, mottled grayish-orange and grayish-brown, argillaceous .

Shale, soft, grayish-brown _...

Shale, hard, fissile, brownish-black; phosphatic depauperate fossils in lower $2 \mathrm{ft}$

Galena dolomite:

Noncherty unit:

Dolomite, yellowish-gray, fine-grained, argillaceous $390-401$.

\section{USGS 27}

Location. $1,240 \mathrm{ft}$ west and $270 \mathrm{ft}$ north of southeast corner sec. $31, \mathrm{~T} .88 \mathrm{~N}$., R. 3 E., Iowa.

Driller. A. Judd.

Date. Oct. 27 to Nov. 1, 1955.

Collar altitude. $1,013 \mathrm{ft}$.

Total depth. $321 \mathrm{ft}$.

Depth to water. $105 \mathrm{ft}$.

Sample study and logging. J. W. Whitlow and C. E. Brown.

Surficial:

Depth

(feet)

Soil, glacial drift

$0-15$

Hopkinton dolomite:

Dolomite, pale-grayish-orange, fine-grained; 15 to 40 percent white chert.

Dolomite, as above; chert less than 5 percent . . _._.

Kankakee formation:

Dolomite, grayish-yellow and light-gray; 15 to 60 percent white chert. 
Edgewood dolomite:

Tete des Morts member:

Dolomite, grayish-orange, fine-grained; trace of chert, glauconite, and pyrite

Mosalem member:

Dolomite, light-olive-gray, shaly, argillaceous, black-specked; trace to 5 percent gray chert.

Dolomite, olive-gray, shaly, black-specked; phosphatic nodules and greenish-gray shale in lower $5 \mathrm{ft}$; trace of glauconite

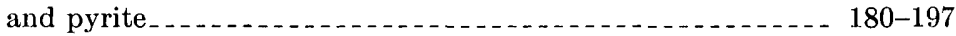

Maquoketa shale:

Brainard member:

Shale, soft, greenish-gray _ _

Shale, soft, olive-gray _. $260-280$

Brown shaly unit:

Shale, pale-brown, soft; fine-grained, argillaceous dolomite__- 280-295

Shale, brownish-gray, soft ... _. _ _._. _ _ _ _ _ _ _ _ 295-310

Shale, brownish-black; phosphatic depauperate fossils in lower $2 \mathrm{ft}$

Galena dolomite:

Noncherty unit:

Dolomite, gray, fine-grained, argillaceous

\section{USGS 28}

Location. 2,460 ft. east and $620 \mathrm{ft}$. south of the northwest corner of sec. 32 , T. 88 N., R. 3 E., Iowa.

Driller. L. Schloeman.

Date. Oct. 19 to $20,1955$.

Collar altitude. $886.5 \mathrm{ft}$.

Total depth. $165 \mathrm{ft}$.

Depth to water. $13 \mathrm{ft}$.

Sample study and logging. C:. E. Brown and J. W. Whitlow.

Surficial:

Soil, broken rock, and green clay . . .

Maquoketa shale:

Brainard member:

Shale, soft, greenish-gray and bluish-gray; plastic when. wet.-

Brown shaly unit:

Dolomite, grayish-brown, fine-grained, argillaceous

Shale, soft, light-grayish-brown _._._. _ _ _ _ _ _ _ _ _. 132-155

Shale, moderately hard, brownish-black, dolomitic; phosphatic depauperate fossils in lower $2 \mathrm{ft}$. $155-161$

Galena dolomite:

Noncherty unit:

Dolomite, light-gray, fine-grained, argillaceous 
USGS 29

Location. $1,000 \mathrm{ft}$ north and $680 \mathrm{ft}$ east of the southwest corner sec. 33, T. $88 \mathrm{~N}$, R. 3 E., Iowa.

Driller. L. Schloeman.

Date. Oct. 20 to $21,1955$.

Collar altitude. $840 \mathrm{ft}$.

Total depth. $130 \mathrm{ft}$.

Depth to water. $12 \mathrm{ft}$.

Sample study and logging. C. E. Brown and J. W. Whitlow.

Maquoketa shale:

Brainard member:

Depth

( feet)

$\begin{array}{lr}\text { Shale, soft, yellowish-green and bluish-gray } & 0-70 \\ \text { Shale, soft, brownish-gray } & 70-85\end{array}$

Brown shaly unit:

Dolomite, mottled brownish-gray and light-olive-gray, argil-

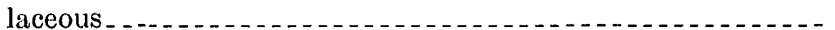

Shale, soft, grayish-brown, silty .........................

Shale, moderately hard, dark-brown; phosphatic, depauperate fossils in lower $2 \mathrm{ft}$

Galena dolomite:

Noncherty unit:

Dolomite, yellowish-gray, medium-grained, argillaceous

$121-1.30$

\section{USGS 30}

Location. $680 \mathrm{ft}$ north and $300 \mathrm{ft}$ west of the southeast corner sec. 1. T. $87 \mathrm{~N}$, R. 2 E., Iowa.

Driller. L. Schloeman.

Date. Oct. 27 to Nov. 1, 1955.

Collar altitude. $1,014.4 \mathrm{ft}$.

Total depth. $350 \mathrm{ft}$.

Depth to water. $15 \mathrm{ft}$.

Sample study and logging. C. E. Brown and J. W. Whitlow.

Surficial:

Soil, silty, dark-brown; numerous chert and dolomite fragments...

Depth

$($ feet)

$0-19$

Hopkinton dolomite:

Dolomite, grayish-yellow, fine-grained, dense; 10 to 50 percent very light gray porcelaneous chert

Dolomite, as above; 1 to 5 percent chert as above

Kankakee formation:

Dolomite, light-gray to grayish-orange, fine grained, dense; 20 to 60 percent white and light-gray porcelaneous chert...........

Edgewood dolomite:

Tete des Morts member:

Dolomite, light-gray to grayish-yellow, fine-grained, slightly porous; glauconite grains common . ... . . . . . . . . . . 115-1.35

Mosalem member:

Dolomite, olive-gray, dense, argillaceous, fine-grained; trace of

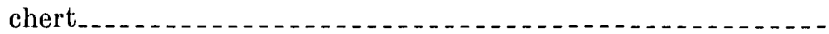

Dolomite, olive-gray, black-specked, fine-grained, argillaceous; quartz silt, brown-shale partings, and pyrite common 
Maquoketa shale:

Brainard member:

Shale, soft, greenish-gray and light-gray, silty; slightly $\begin{gathered}\text { Depth } \\ (\text { fect })\end{gathered}$ dolomitic

Brown shaly unit:

Dolomite; grayish-brown, medium-grained, argillaceous; lightgray, sof t shale

Shale, dark-brown and light-brown; phosphatic depauperate fossils in lower $2 \mathrm{ft}$

Dalena dolomite:

Noncherty unit:

Dolomite, light-gray, fine-grained, argillaceous 345-350 


\section{INDEX}

A

Acknowledgments

Alluvial terraces

Alpine mine

Altitude of report area

Anticlines.

Arachnophyllum mamillare.

Atry'pa reticularis

A venue top mine

\section{B}

Barite

Base level-

Beadle mine.

Bellevue, Iowa

Beloitoceras

Biotite.

Black Crevice

Brainard, Iowa

Brugh mine

Buncombe Creck

\section{C}

Calcite $22,29,30,58,49,71$

Cambrian rocks, stratigraphy thickness.

Catenipora huronensis

Catfish Creek - - -

incised meanders.

Middle Fork.

North Fork

terrace deposits

valley-train deposits

Caves, occurrence.

$$
\text { origin. }
$$

Page Decorah formation-Continued Ion dolomite member.

Page lithology . . . . . . . . . . . . . . 15, 16, 68, 70, 75 pitch-and-flat deposits. . . . . . . . ...... 56,57,60, 61 Spechts Ferry shale member . . . ..... 15, 68, 70 stratigraphy..................... $68,70,75$ thickness.................... 15,48

Depauperate fauna. . . . . . . . . . . $\ldots 25,26,37,54$ Descriptions of mines...................... $62-63$ Differential compaction................. 13, 42

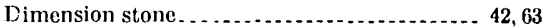
Diplograptus peosta........................ 25 Disconformity ..... $\ldots \ldots \ldots \ldots \ldots .27,31,49$ Dodgeville peneplain. . . . . . Dolomitization . . . . . . . . . . . . . . . . . . . 20, 22, 61 Dolorthoceras sociale. See Michelinoceras sociale.



Dresbach sandstone. ..................... 12,64

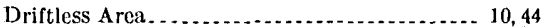
Driftless Area . Dubuque, Iowa........... 8, 12, 13, 51, 52, 55, 59, 64 Durango, lowa. ................. 57, 60, 63

\section{$\mathbf{E}$}

East Dubuque, Iowa. . ................... 8,51

East Lockey Drybone mine. . . . . . . . . . . . . 62; pl. 5

Eau Claire sandstone........................ 12

Edgewood dolomite, fossil content. . . . . . 30, 37, 40 lithology _ . . . . 30, 31, 33, 34-40, 59, 77, 79, 81, 82-90 Mosalem nember... 30, 33, 36-39, 77, 79, 81, 82-90 stratigraphy $\ldots \ldots \ldots \ldots . . . \ldots . .23,30,31$, $32,33,34-40,41,42,77,79,81,82-90$ Tete des Morts member 30 ,

$33,36,39-40,42,77,81,82-90$ 1 hickness topographic expression .............. 39, 40

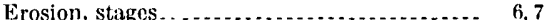

Center Grove, Iowa. . . . . . . . 60

Cerrusite............................... 57

Chalcedony $\ldots \ldots \ldots \ldots \ldots$

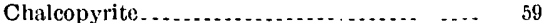

Chert, occurrence.............. $20,21,30,31,38,40,42,43,44,45,46,54,61,63$ origin............................. 21

Clinton iron-bearing beds. . . . . . . . . . . . . . .... 28

Collophane........... 29, 37

Cornulites sterlingensis..................... 28

Cornulites zone. ................. 30, 33, 39

Crystal Leka Cave....................... 10

Cuesta. ................... 10,43

Cystiphyllum sp.......................... 44

\section{D}

Decorah formation, fossil content Guttenberg limestone member
Errat:es 45,46

Farley, Iowa. . . . .

Faults..................... 51,56

Fanosites brownsportensis................ 44

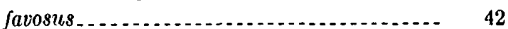

Field instruments. . . . .

Flexicalymene sp........................... 27 classification and definition _............ 47, 48 origin....................... 47 relation to joints................... 60 trend................................. 47 Forest City basin .................... 46, 47, 49 Fossils, occurrence.... 15, 17, 19, 20, 21, 22, 25, 26, 27. 28 Franconia sandstone. sp.

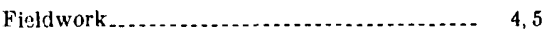

Folds, axes . . ........ 47, 48, 49, 51, 60
15,16 $16,61,68,70,75$ 
$\begin{array}{cr}\text { G } & \text { Page } \\ \text { Galena_...... } & \text { G2, 51, 52,54, 55, 57, 58, 59, 61, 62, 63 }\end{array}$ Galena dolomite, caves...................... 10 cherty unit.... 17-21, 47, 48, 56, 60, 62, 68, 70, 71-90 Cummingsville member. drainage.

Dubuque shaly member fossil content ................. 17, 19,20,21, 22 gash-vein deposits................... 22, 53, 55 jointing ............................ 7, 21,60 lithology .......... 16-22, 57, 58,59,61, 63, 68-90 noncherty unit......... 21-22, 47, 48, 68, 70, 71-90 Prosser cherty member................ 16, 17, 21 sinkholes.

Stewartville massive member ......... 16, 21, 22 stratigraphy $\ldots . . \ldots \ldots \ldots \ldots \ldots . . . .7,16-22,27,32,68-90$ structure................................ 47 thickness................................ 17, 48 topographic expression........... 7, 16, 17, 21, 22 water-bearing properties................. 64 weathering characteristics......... 16, 17,21, 27

Galena, III................................ 16, 47 Gash-vein deposits...... 22, 52, 53-55, 57, 58, 59,61, 62 Glacial drift............................. 44-46,54

Glaciation, age .......................... 8, 44, 45 effects on drainage....................... melt water

Glauconite 37,40

Goosehorn mine

Gower dolomite

Granger Creek

Ground water $\ldots \ldots \ldots \ldots \ldots \ldots \ldots . . \ldots \ldots, 54,58,60,64$ Guides to ore.............................. 61-62 Guttenberg, Iowa.......................... 15

\section{H}

Halysites $\mathrm{sp}$

Hematite.............................. 29, 30

Hemimorphite......................... 58

Hopkinton dolomite, fossil content . . . . . . . . 43, 44 lithology . . . . . . . ..... $31,33,43-44,63,81,82-90$ stratigraphy ...... $31,32,33,41,42,43-44,81,82-90$ thickness................... 33, 43 weathering characteristics............... 44 topographic expression.................. 43 Hopkinton, Iowa

Horseshoe Bluff ............................ 7,21

Illinois basin ...................... 46,49

Illite.

Ion, Iowa. .

Joints, attitude.................... 49, 50,51,53,56, 62 controlling dip.......................... 48 controlling erosion................... 9, 10,49 controlling mineral deposits..... 53-55, 58, 59, 62 relation to folds trend......................... 10,49,50,51,53 in Galena dolomite............... 7, 10,21,51,53

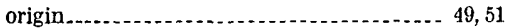

K

Kane mine 55,57

Kankakee formation, fossil content......... 40,42 lithology . . . ......... 30, 31, 33, 40-42, 63, 81, 82-90 stratigraphy ......... $30,31,33,40-42,43,81,82-90$ thickness.
Kankakee formation-Continued Page weathering characteristics . .............. 42

Kankakee River........................... 40

Karst topography . . . . . . . . . . . . . . . . . 10

Kemling cave............................. 10,11

\section{$\mathbf{L}$}

Laboratory methods

Lancaster peneplain ........................

Laterite

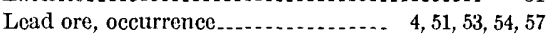
production -

Limonite ............ 26, 27, 28, 29, 30,34, 38, 44, 58, 61

Lingula iowensis............................ 22

Lithographic limestone....................... 14

Little Maquoketa River ....................... 22,51

Location of report area . . . . . . . . . . . . . . . . 2,3

Lockey Drybone mine. . . . . . . . . . . . . . . . . . 57, 58

Loess........................................ 7,46

Lore Hill_................................ 28

Lytle Creek ...............................

Malachite .............. 59

Maquoketa River, North Fork............. 7

Maquoketa shale, Brainard member......... 23,

$25,27-28,30,34,39,63,72-90$ brown shaly unit ............ $25-27,59,64,71-90$ Clermont shale......................... 23 drainage ................................

Elgin shaly limestone................... 23, 25

Fort Atkinson limestone

fossil content..... 25, 26, 27, 28, 30,31,34,37, 54, 64 lithology _................... 22-31, 34,61, 71-90

Neda member............... 23, 25, 28-31, 39, 82' stratigraphy ........................ $22-31$,

$32,33,34,38,39,42,55,60,71-90$ thickness................. 23, 24, 28,34, 36, 40,47 topographic expression . . . . . . . . . . . $6,7,9,23$ water-bearing properties................. 64 weathering characteristics................ 23, 29 Marcasite.............................. 26, 54, 58, 59 Martin, Lawrence, quoted .................. 6 Mayville iron ore Mayville, $W$ is............................. 28 McGregor, Iowa............................ 14

Meanders, incised......................... 8,9

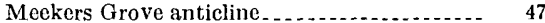
Metallic content of drill holes................ 69 $70,71,73,76,77,78,79,80,83$ Michelinoceras sociale........................ 25

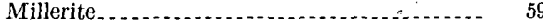
Mineralogy of deposits..................... 57-59 Mineralization _ $14,15,16,20,22,48,53-62$ Mining, history ............................ 51-53

Mississippi River, diversion by ice............ 8 erosional history . . . . . . . . . . . . . . . $7-9 ; 17$ flood plain........................ $7,8,51,63,64$ incised meanders terrace deposits

Montmorillonite........................... 58

Mount Simon sandstone, stratigraphy ........ 12

Neda formation, See Maquoketa shalc.

Neda, Wis.................................. 28

Niagaran cuesta................ 6, 9, 23,36, 40, 63, 64 


\section{$\mathbf{0}$}

Ordovician rocks, jointing stratigraphy

Outwash material, thickness

\section{$\mathbf{P}$}

Paleontologic studies.

Paragenesis.

Pecatonica River

Pentamerus oblongus.

sp.

Petroliferous rock

Phosphatic nodules....... 14, 15, 26-30,37,38, 39, 63, 64

Pitch-and-flat deposits. $55-57,59,60,61,62$

Platteville formation, Glenwood shale member

13,14

lithology .......................... 13-14, 76

McGregor limestone member.......... 15, 61, 76

Pecatonica dolomite member............. 14

Quimbys Mill member................ 14,61, 76

stratigraphy ............................ 76

thickness

Platymerella manniensis.

Prairie du Chien group, lithology

thickness.

water-bearing properties

Prasopora zone.

Precambrian rocks.

Propora americana.........................

Public lands, mineral-bearing . ...............

Pyrite.................... 22, 29, 30, 37, 38, 54, 58, 59

Pyrolusite

$22,29,30,37,38,54,58,58$

Q

Quartz

$13,14,17,28,37,38,42,44,45,72$

Quaternary deposits........................ 44-46

Quimbys Mill, Wis

\section{$\mathbf{R}$}

Receptaculites oueni. -

Receptaculites zone, lower.

middle.

upper.

Reef masses.

Richey, III

Rockdale, lowa

Royco and Frost mine.

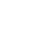

$\mathbf{S}$

Sabula, Iowa

Sauconite.

Shullsburg, Wis

Silurian rocks, caves

cuesta.

jointing.

$6,31,46$

lithology

$10,49,50$

outcrops

sinkholes

$2,40,47$
Silurian rocks-Coníinued Page stratigraphy ..................... 5, 30,31-44,60 water-bearing properties.................. 64

Sinkholes, occurrence

origin $\ldots \ldots$

Sloan shaft.... ........................... 58

Slumpage.......................... 9, $13,39,40,48$

Smithsonite ..................... $52,55,57,58,62,63$

Solution breccia........................... 57,62

Spechts Ferry, Iowa......................... 14, 15

Sphalerite........... 22, 37, 52, 54, 55, 57, 58, 59,62, 63

Springs_.................................. 7,64

Stalactites................................... 10

Stalagmites.................................... 10

St. Peter sandstone, lithology ............. 13

stratigraphy .............................. 13, 14

thickness................................ 13

water-bearing properties................ 64

Streams, capture.......................... 9 channels............................ 7, 46, 63

intermittent............................... 7

patterns.................................... 6

perennial.............................. 7

Structural relief. . . . . .

Structure .................................. 46-51, 60

controlling erosion.

field work.............................. 5,47

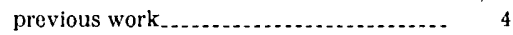

regional dip............................ 47,48

Stylolites.................................... 30, 40

Synclines...................... 9, 10,47,48, 60, 62, 64

$\mathbf{T}$

Tete des Morts River....... 7, 23, 39, 40, 42, 47, 51, 63 Till................................... 44-46,61,71

Topography $\ldots . . . . . . . . . . . . . . . . . . . . . . .6$

Travertine . . . . .

Trempealcau formation......................... 12

Tripoli.

Unconformity _............... 13, 23, 27, 33, 34, 40

Upper Mississippi zinc-lead district, location. . $\quad 2,3$

Vialley-train deposits...................... $s$

Wad . . . .

Wallrock alteration

Water table................. 10, 22, 54, 55, 58,60, 62

40 Wells, water................ 5, 8, 9, 12, 13, 43, 46, 56, 64

58 West Lockey Drybone mine. . . . . . . ..... 62; pl. 6

Winston dolomite..................... 34

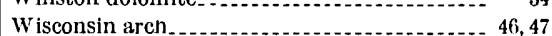

Wisconsin dome.......................... 46,47

Zinc ore, occurrence. ................ 4, 52,54,55,57

production . . 